\title{
Statistics on
}

\section{Post-School Education}

\section{and Training}

\section{in South Africa: 2013}

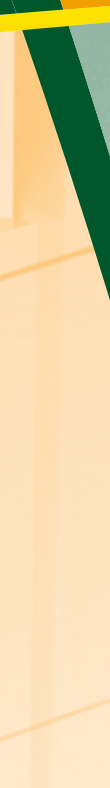





\section{Statistics on \\ Post-School Education and Training in South Africa: 2013}

Released in March 2015

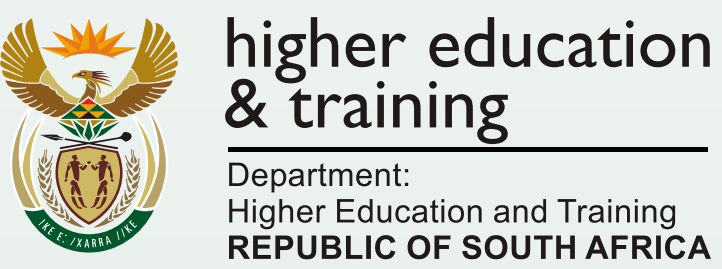


Department of Higher Education and Training

123 Francis Baard Street

Pretoria

South Africa

Private Bag X174

Pretoria

0001

Tel.: 0800872222

Published by the Department of Higher Education and Training.

www.dhet.gov.za

(C) Department of Higher Education and Training, 2015.

This publication may be used in part or as a whole, provided that the Department of Higher Education and Training is acknowledged as the source of information.

The Department of Higher Education and Training does all it can to accurately consolidate and integrate national education information, but cannot be held liable for incorrect data and for errors in conclusions, opinions and interpretations emanating from the information. Furthermore, the Department cannot be held liable for any costs, losses or damage that may arise as a result of any misuse, misunderstanding or misinterpretation of the statistical content of the publication.

ISBN: 978-1-77018-775-7

This report is available on the Department of Higher Education and Training's website: www.dhet.gov.za

Enquiries:

Tel: $+27(012) 3125212$

Fax: +27 (012) 3262069

Email: HETIS.Officer@dhet.gov.za 


\section{FOREWORD}

It is my pleasure to present to you the fourth issue of Statistics on Post-School Education and Training in South Africa. The three previous similar reports published by the Department of Higher Education and Training can be found on the Department's website at www.dhet.gov.za

The Department issued a release date schedule to the public for this publication. The challenges we faced in meeting the release date are mostly and principally linked to the shift of Further Education and Training/Technical and Vocational Education and Training (FET/TVET) Colleges and Adult Education and Training (AET) functions from Provincial Education Departments to the Department of Higher Education and Training.

Post-school education and training institutions include: public and private Higher Education Institutions (HEls); public FET/TVET and private FET

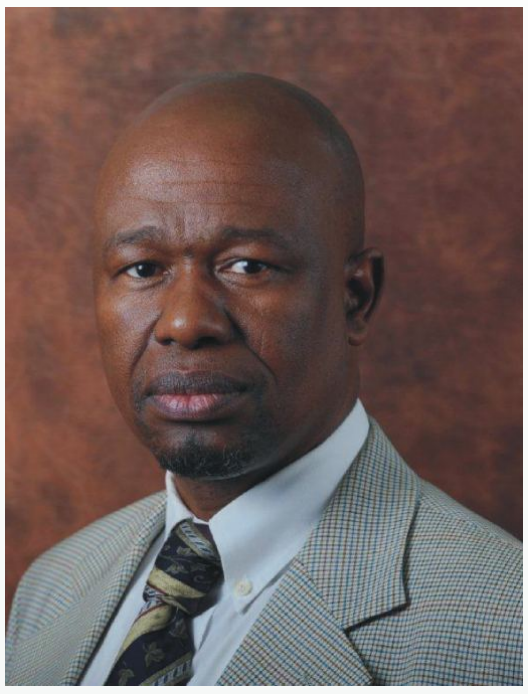
Colleges; and public and private AET Centres.

This report provides statistical information on student enrolment, graduation and certification, and institutional staffing levels at post-school education and training institutions, as well as other relevant information from its entities, e.g. workplace-based education and training. It also includes key financial statistics pertaining to the National Student Financial Aid Scheme, the Skills Levy and funds allocated to key components of the post-school education and training system. This report serves as an important resource for planning and the allocation of budgetary resources in the post-school education and training sector. It is a reference document for reporting processes in government, including the monitoring and evaluation of post-school education and training. In addition, it provides statistics for use in research, policy and decision making at the different levels of the system, and by the public. It, therefore, makes a crucial contribution to the achievement of the goals of the post-school sector.

Public FET Colleges have been renamed TVET Colleges while private FET Colleges have been renamed private Colleges in terms of the Further Education and Training Colleges Amendment Act, 2013, (Act No. 1 of 2013) in Government Gazette No. 36271. The Act came into effect on 6 October 2014 in terms of a proclamation (No. 68 of 2014) by order of the President of the Republic of South Africa (Government Gazette No. 38072).

The Department uses the racial descriptors: "African", "Coloured", "White" and "Indian/Asian" for planning, monitoring and funding purposes. The Department places on record that these racial descriptors, which characterised apartheid policies and practices in the past, are being used to provide historical context and comparisons as well as to describe and measure the effects of present policy and practice on redressing the inequities of the past as required by the Constitution of South Africa.

The Department is striving to make this report more accurate and responsive to stakeholders' needs. Feedback, including suggestions for improvement, can be emailed to: HETIS.Officer@dhet.gov.za

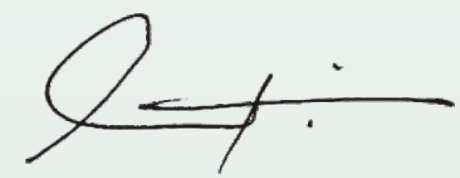

MrG.F. Qonde

Director-General: Department of Higher Education and Training

Pretoria, South Africa 


\section{ACKNOWLEDGEMENTS}

The Department of Higher Education and Training wishes to thank the heads and staff members of the nine provincial Education Management Information System units, Higher Education Institutions, Further Education and Training/Technical and Vocational Education and Training Colleges, Adult Education and Training Centres, Sector Education and Training Authorities, the National Artisan Moderation Body, the National Student Financial Aid Scheme, and the National Skills Fund for providing the data to make this publication possible. 


\section{TABLE OF CONTENTS}

LIST OF TABLES

LIST OF FIGURES $\quad x$

LIST OF ACRONYMS AND ABBREVIATIONS

1. INTRODUCTION

2. THE PROVISIONING OF POST-SCHOOL EDUCATION AND TRAINING (PSET): A STATISTICAL OVERVIEW 3

3. HIGHER EDUCATION AND TRAINING 5

3.1 ENROLMENT IN PUBLIC AND PRIVATE HIGHER EDUCATION INSTITUTIONS (HEIS) 5

3.2 PUBLIC HEIS

$\begin{array}{ll}3.2 .1 \text { Introduction } & 6\end{array}$

3.2.2 Enrolment in public HEls 6

$\begin{array}{ll}\text { 3.2.3 Graduates in public HEls } & 15\end{array}$

$\begin{array}{lr}3.2 .4 \text { Staffing in public HEls } & 20\end{array}$

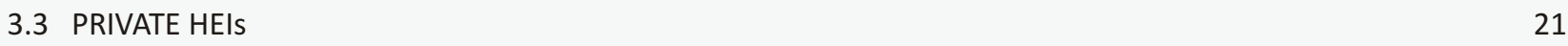

$\begin{array}{ll}3.3 .1 \text { Introduction } & 21\end{array}$

$\begin{array}{lr}\text { 3.3.2 Enrolment in private HEls } & 21\end{array}$

4. FURTHER EDUCATION AND TRAINING/TECHNICAL AND VOCATIONAL EDUCATION AND TRAINING (FET/TVET) 22

4.1 OVERVIEW OF PUBLIC FET/TVET AND PRIVATE FET COLLEGES 22

4.2 PUBLIC FET/TVET COLLEGES $\quad 25$

\begin{tabular}{ll}
4.2 .1 & Introduction \\
\hline
\end{tabular}

$\begin{array}{ll}\text { 4.2.2 Overview of the public FET/TVET sector } & 25\end{array}$

4.2.3 Enrolment in public FET/TVET Colleges 26

$\begin{array}{lll}\text { 4.2.4 Staffing in public FET/TVET Colleges } & 31\end{array}$

4.2.5 Examination results in public FET/TVET Colleges 33

4.3 PRIVATE FET COLLEGES

$\begin{array}{ll}\text { 4.3.1 Introduction } & 40\end{array}$

$\begin{array}{lll}\text { 4.3.2 Overview of the private FET sector } & 40\end{array}$

4.3.3 Enrolment in private FET Colleges $\quad 41$

$\begin{array}{ll}\text { 4.3.4 Staffing in private FET Colleges } & 42\end{array}$

4.3.5 Examination results in private FET Colleges $\quad 43$

5. ADULT EDUCATION AND TRAINING (AET) 49

5.1 OVERVIEW OF PUBLIC AND PRIVATE AET CENTRES

5.2 PUBLIC AET CENTRES

$\begin{array}{llr}\text { 5.2.1 } & \text { Introduction } & 50 \\ \text { 5.2.2 } & \text { Overview of public AET Centres } & 50 \\ \text { 5.2.3 } & \text { Enrolment in public AET Centres } & 51 \\ \text { 5.2.4 } & \text { Staffing in public AET Centres } & 52 \\ \text { 5.2.5 } & \text { Examination results in public AET Centres } & 53\end{array}$ 
\begin{tabular}{l}
5.3 PRIVATE AET CENTRES \\
\hline
\end{tabular}

$\begin{array}{llr}5.3 .1 & \text { Introduction } & 58\end{array}$

$\begin{array}{ll}\text { 5.3.2 Overview of private AET Centres } & 58\end{array}$

$\begin{array}{ll}\text { 5.3.3 Enrolment in private AET Centres } & 59\end{array}$

$\begin{array}{ll}\text { 5.3.4 Staffing in private AET Centres } & 60\end{array}$

6. SECTOR EDUCATION AND TRAINING AUTHORITY (SETA)-SUPPORTED LEARNING PROGRAMMES 61

6.1 INTRODUCTION 61

6.2 REGISTRATION AND CERTIFICATION OF SETA-SUPPORTED LEARNING PROGRAMMES: TREND DATA 62

6.2.1 Workers registered for SETA-supported learning programmes 63

6.2.2 Workers certificated in SETA-supported learning programmes 64

6.2.3 Unemployed persons registered for SETA-supported learning programmes 65

6.2.4 Unemployed persons certificated in SETA-supported learning programmes 66

6.3 ARTISANS 67

$\begin{array}{lll}6.3 .1 & \text { Introduction } & 67\end{array}$

6.3.2 Learners entering artisanal learning programmes 68

$\begin{array}{ll}\text { 6.3.3 Learners completing artisanal learning programmes } & 69\end{array}$

7. FUNDING IN THE POST-SCHOOL EDUCATION AND TRAINING (PSET) SECTOR

$\begin{array}{lll}7.1 & \text { INTRODUCTION } & 71\end{array}$

7.2 FUNDING OF KEY PSET PUBLIC INSTITUTIONS

7.3 NATIONAL STUDENT FINANCIAL AID SCHEME (NSFAS) 73

$\begin{array}{ll}7.3 .1 & \text { Introduction } \\ \end{array}$

$\begin{array}{ll}\text { 7.3.2 NSFAS beneficiaries and amount provided } & 73\end{array}$

$\begin{array}{lll}\text { 7.3.3 Funza Lushaka bursary scheme } & 74\end{array}$

7.4 THE SKILLS DEVELOPMENT LEVY
75

\begin{tabular}{ll}
7.4 .1 & Introduction \\
\hline
\end{tabular}

$\begin{array}{ll}\text { 7.4.2 Distribution of the Skills Development Levy } & 75\end{array}$

7.5 GRANTS PROVIDED BY THE NATIONAL SKILLS FUND (NSF) 76

$\begin{array}{lll}7.5 .1 & \text { Introduction } & 76\end{array}$

7.5.2 Number of projects and beneficiaries supported by the NSF 76

$\begin{array}{lll}7.5 .3 & \text { NSF infrastructure grants } & 78\end{array}$

8. EXPLANATORY NOTES 79

$\begin{array}{lll}8.1 & \text { INTRODUCTION } & 79\end{array}$

$\begin{array}{ll}8.2 \text { SCOPE } & 79\end{array}$

8.3 METHODOLOGY
8.4 RESPONSERATES

$\begin{array}{lll}8.4 & \text { RESPONSE RATES } & 79\end{array}$

9. GLOSSARY 80

10. CONTACT DETAILS 


\section{LIST OF TABLES}

Table 1: Overview of PSET institutions, in 2013

Table 2: Number of workers and unemployed persons registered for and certificated in SETA-supported learning programmes, by programme type, in 2013

Table 3: Number of first-time undergraduate students enrolled in public HEls, by institution, from 2009 to 2013

Table 4: Number of students enrolled in public HEls, by major field of study, qualification type and institution, in 2013

Table 5: Number of students enrolled in public HEls, by attendance mode, population group, gender and institution, in 2013

Table 6: Number of foreign students enrolled in public HEls, by country, attendance mode and qualification type, in 2013

Table 7: Full-Time Equivalent (FTE) student enrolment in public HEls, by attendance mode, major field of study and institution, in 2013

Table 8: Number of students who graduated from public HEls, by major field of study, qualification type and institution, in 2013

Table 9: Summaries of graduation rates in public HEls, by qualification type and institution, in 2013

Table 10: Undergraduate success rates of students in public HEls, by attendance mode, population group, and institution, in 2013

Table 11: Number and percentage of permanent staff in public HEls, by population group, gender, personnel categories and institution, in 2013

Table 12: Number of students enrolled in private HEls, by gender, from 2011 to 2013

Table 13: Number of students enrolled in private HEls, by population group and nationality, from 2011 to 2013

Table 14: Number of students enrolled in public FET/TVET and private FET Colleges, by institutional type, qualification and province, in 2013

Table 15: Number of students in public FET/TVET and private FET Colleges who wrote and completed examinations, by qualification type, from 2011 to 2013

Table 16: Number of public FET/TVET Colleges, lecturers and students, by province, in 2013

Table 17: Number of students enrolled in public FET/TVET Colleges, by college and qualification category, in 2013

Table 18: Number of students enrolled in public FET/TVET Colleges, by qualification category and population group, in 2013

Table 19: Number of students enrolled in public FET/TVET Colleges, by qualification category and gender, in 2013

Table 20: Number of students enrolled in public FET/TVET Colleges for Report 191 programmes, by level and gender, in 2013

Table 21: Number of students enrolled in public FET/TVET Colleges for the NC(V), by qualification level and gender, in 2013

Table 22: Number of students enrolled in public FET/TVET Colleges, by qualification category and age group, in 2013

Table 23: FTE student enrolment in individual public FET/TVET Colleges, by qualification category, in 2013

Table 24: Number of staff and students in individual public FET/TVET Colleges, in 2013

Table 25: Number of staff in individual public FET/TVET Colleges, by staff category and gender, in 2013 
Table 26: Number of students in public FET/TVET Colleges who registered, wrote examinations and completed national qualifications, by qualification category and gender, in 2013

Table 27: Number of students in public FET/TVET Colleges who registered, wrote and completed NC(V) qualifications, by province and level, in 2013

Table 28: Number of students in public FET/TVET Colleges who registered, wrote and completed Report 191 N1 to N3 qualifications for Engineering Studies, by province and programme, in 2013

Table 29: Number of students in public FET/TVET Colleges who registered, wrote and completed Report 191 N4 to N6 part-qualifications for Engineering Studies, by province and programme, in 2013

Table 30: Number of students in public FET/TVET Colleges who registered, wrote and completed Report 191 N4 to N6 part-qualifications for Business Studies, by province and programme, in 2013

Table 31: Number of students in public FET/TVET Colleges who registered, wrote and completed the NC(V) Level 4 qualification, by programme and gender, in 2013

Table 32: Number of students in public FET/TVET Colleges who registered, wrote and completed the Report 191 N6 part-qualification, by programme and gender, in 2013

Table 33: Number of lecturers and students in private FET Colleges, by province, in 2013

Table 34: Number of students enrolled in private FET Colleges, by qualification category and gender, in 2013

Table 35: Number of students in private FET Colleges, by organising fields, in 2013

Table 36: Number of staff in private FET Colleges, by category and gender, in 2013

Table 37: Number of students in private FET Colleges who registered, wrote and completed national qualifications, by qualification category and gender, in 2013

Table 38: Number of students in private FET Colleges who registered, wrote and completed NC(V) qualifications, by level, in 2013

Table 39: Number of students in private FET Colleges who registered, wrote and completed Report 191 N1 to N3 part-qualifications for Engineering Studies, by programme, in 2013

Table 40: Number of students in private FET Colleges who registered, wrote and completed Report 191 N4 to N6 part-qualifications for Engineering Studies, by programme, in 2013

Table 41: Number of students in private FET Colleges who registered, wrote and completed Report 191 N4 to N6 part-qualifications for Business Studies, by programme, in 2013

Table 42: Number of students in private FET Colleges who registered, wrote and completed the NC(V) Level 4 qualification, by programme and gender, in 2013

Table 43: Number of students in private FET Colleges who registered, wrote and completed the Report 191 N6 part-qualification, by programme and gender, in 2013

Table 44: Learner enrolment in public and private AET Centres, by institutional type and level, in 2013

Table 45: Number of public AET Centres, educators and learners, by province, in 2013

Table 46: Number of learners in public AET Centres, by province and level, in 2013

Table 47: Number of staff in public AET Centres, by province, staff category and gender, in 2013

Table 48: Number of learners in public AET Centres who registered, wrote and completed the GETC-ABET Level 4 qualification, from 2011 to 2013

Table 49: Number of learners in public AET Centres who registered, wrote and completed the GETC-ABET Level 4 qualification, by province, in 2013

Table 50: Number of learners in public AET Centres who registered, wrote and completed the GETC-ABET Level 4 qualification, by province and gender, in 2013 
Table 51: Number of learners in public AET Centres who wrote and passed GETC-ABET Level 4 Learning Areas by content, in 2013

Table 52: Number of learners in public AET Centres who wrote and passed GETC-ABET Level 4 Learning Areas, by language, in 2013

Table 53: Number of private AET Centres, educators and learners, by province, in 2013

Table 54: Number of learners enrolled in private AET Centres, by province and level, in 2013

Table 55: Number of staff in private AET Centres, by province, staff category and gender, in 2013

Table 56: Number of workers and unemployed persons registered for and certificated in SETA-supported learning programmes, by programme type, from 2011/12 to 2013/14

Table 57: Number of workers registered for SETA-supported learning programmes, by programme type, and SETA, in 2013/14

Table 58: Number of workers certificated in SETA-supported learning programmes, by programme type, in 2013/14

Table 59: Number of unemployed persons registered for SETA-supported learning programmes, by programme type, in $2013 / 14$

Table 60: Number of unemployed persons certificated in SETA-supported learning programmes, by programme type, in $2013 / 14$

Table 61: Number of learners entering artisanal learning programmes, by organisation, from 2011/12 to 2013/14

Table 62: Number of learners completing artisanal learning programmes by organisation, from 2011/12 to 2013/14

Table 63: Number of artisans certificated by SETAs and INDLELA, by economic sector, in 2013

Table 64: Funding of key PSET institutions, from 2011/12 to 2013/14

Table 65: Number of students who have received loans/bursaries from NSFAS and the amount provided, by sub-sector, from 2011 to 2013

Table 66: Number of students in HEls who received a Funza Lushaka bursary and the amount provided, from 2011 to 2013

Table 67: Distribution of the Skills Development Levy, from 2011/12 to 2013/14

Table 68: Number of NSF-supported projects and beneficiaries, by province, from 2011/12 to 2013/14

Table 69: Distribution of NSF across key projects, number of beneficiaries and amount disbursed, from 2011/12 to $2013 / 14$ 


\section{LIST OF FIGURES}

Figure 1: Percentage distribution of student enrolment in PSET institutions, in 2013

Figure 2: $\quad$ Number of students enrolled in public and private HEls, from 2009 to 2013

Figure 3: $\quad$ Number of students enrolled in public HEls, by attendance mode, from 2009 to 2013

Figure 4: $\quad$ Number of students enrolled in public HEls, by major field of study, from 2011 to 2013

Figure 5: $\quad$ Percentage distribution of student enrolment in public HEls, by qualification type, in 2013

Figure 6: Percentage distribution of student enrolment in public HEls, by attendance mode and gender, in 2013

Figure 7: $\quad$ Number of graduates in public HEls, by major field of study, from 2011 to 2013

Figure 8: Percentage distribution of average undergraduate success rates in public HEls, by contact education programme and population group, in 2013

Figure 9: $\quad$ Number of students enrolled in public FET/TVET and private FET Colleges, from 2011 to 2013

Figure 10: Number of students enrolled in public FET/TVET Colleges, by qualification category, from 2010 to 2013

Figure 11: Number of students enrolled in private FET Colleges, by qualification category, from 2010 to 2013

Figure 12: Number of learners enrolled in public and private AET Centres, from 2011 to 2013

Figure 13: Number of learners in public AET Centres, by programme, from 2012 to 2013

Figure 14: Number of learners in private AET Centres, by programme, from 2012 to 2013 


\section{LIST OF ACRONYMS AND ABBREVIATIONS}

ABET

AET

AGRISETA

BANKSETA

CATHSSETA

CETA

CHIETA

DHET

DOE

ETDP SETA

EWSETA

FASSET

FET

FETMIS

FOODBEV

FP\&MSETA

FTE

GETC

GETC-ABET

HE

HEI

HEMIS

HEQSF

HWSETA

INDLELA

INSETA

IPAP

LGSETA

MERSETA

MICT SETA

MQA

NAD

NADSC

NAMB

NAMB-NAD
Adult Basic Education and Training

Adult Education and Training

Agriculture Sector Education and Training Authority

Banking Sector Education and Training Authority

Culture, Arts, Tourism, Hospitality and Sports Sector Education and Training Authority

Construction Education and Training Authority

Chemical Industries Education and Training Authority

Department of Higher Education and Training

Department of Education

Education, Training and Development Practices Sector Education and Training Authority

Energy and Water Sector Education and Training Authority

Finance and Accounting Services Sector Education and Training Authority

Further Education and Training

Further Education and Training Management Information System

Food and Beverages Manufacturing Industry Sector Education and Training Authority

Fibre Processing and Manufacturing Sector Education and Training Authority

Full-Time Equivalent

General Education and Training Certificate

General Education and Training Certificate: Adult Basic Education and Training

Higher Education

Higher Education Institution

Higher Education Management Information System

Higher Education Qualifications Sub-Framework

Health and Welfare Sector Education and Training Authority

Institute for the National Development of Learnerships, Employment Skills and Labour Assessments

Insurance Sector Education and Training Authority

Industrial Policy Action Plan

Local Government Sector Education and Training Authority

Manufacturing, Engineering and Related Services Sector Education and Training Authority

Media, Information and Communication Technologies Sector Education and Training Authority

Mining Qualifications Authority

National Artisan Development

National Artisan Development Support Centre

National Artisan Moderation Body

National Artisan Moderation Body - National Artisan Development 
NATED

NC (V)

NDP

NGP

NID

NQF

NRF

NSA

NSC

NSDS

NSF

NSFAS

PED

PSET

PSETA

QCTO

RPL

RSA

SAPSE

SAQA

SARS

SASSETA

SERVICES SETA

SET

SETA

TETA

TVET

UNISA

W\&RSETA
National Technical Education

National Certificate (Vocational)

National Development Plan

New Growth Path

National Institute for the Deaf

National Qualifications Framework

National Research Foundation

National Skills Authority

National Senior Certificate

National Skills Development Strategy

National Skills Fund

National Student Financial Aid Scheme

Provincial Education Department

Post-School Education and Training

Public Service Sector Education and Training Authority

Quality Council for Trades and Occupations

Recognition of Prior Learning

Republic of South Africa

South African Post-Secondary Education

South African Qualifications Authority

South African Revenue Service

Safety and Security Sector Education and Training Authority

Services Sector Education and Training Authority

Science, Engineering and Technology

Sector Education and Training Authority

Transport Education and Training Authority

Technical and Vocational Education and Training

University of South Africa

Wholesale and Retail Sector Education and Training Authority 


\section{INTRODUCTION}

The Department of Higher Education and Training (DHET) seeks to improve the capacity of the Post-School Education and Training (PSET) system to meet the skills needs of the country. The Department's objectives are to: a) increase the rate at which the key skills necessary for economic growth and social development are delivered; $b$ ) serve the growing number of young people and adults who seek education and training outside of the schooling system; c) provide alternative entry points into and pathways through the learning system; d) provide quality learning irrespective of where learning takes place (i.e. College, University or workplace); and e) provide easy pathways across the various learning sites.

The Department has oversight over three main categories of PSET institutions, namely: Higher Education Institutions (HEls); public Further Education and Training/Technical and Vocational Education and Training (FET/TVET) Colleges and private FET Colleges; and Adult Education and Training (AET) Centres. Public FET Colleges have been renamed TVET Colleges, while private FET Colleges have been renamed private Colleges in terms of the Further Education and Training Colleges Amendment Act, 2013, (Act No. 1 of 2013), in Government Gazette No. 36271. The Act came into effect on 6 October 2014 in terms of a proclamation (No. 68 of 2014) by order of the President of the Republic of South Africa (Government Gazette No. 38072).

The Department is responsible for ensuring that funds generated through the Skills Development Levy are utilised appropriately and optimally to develop skills needed for the economy and general development.

This report provides institutional, student, programme, staffing and funding statistics on PSET over which it has oversight. It, therefore, does not provide information on PSET that is managed by other government departments and state entities.

The Department draws its data from a number of internal and external databases, as well as from management reports provided by departmental entities. These include:

- The Higher Education Management Information System (HEMIS), which contain data provided to the Department by public HEls;

- Annual reports submitted by registered private HEls;

- The Further Education and Training Management Information System (FETMIS), which contain data provided to the Department by public FET/TVET Colleges and registered private FET Colleges;

- The database on AET Centres, which contain data provided to the Department by Provincial Education Departments (PEDs) and annual reports submitted by private AET Centres;

- The Sector Education and Training Authority (SETA) Learner Management System, which contain data provided to the Department by SETAs;

- Quarterly reports provided to the Department by SETAs;

- Data provided to the Department by the National Artisan Moderation Body (NAMB);

- $\quad$ Reports provided to the Department by the National Skills Fund (NSF); and

- The National Examination Database, which contain administrative data about student examinations and certification for the General Education and Training Certificate-Adult Basic Education and Training (GETC-ABET), the National Certificate (Vocational) [NC(V)] and the "N" qualifications. 
The Department is committed to ensuring that the data it receives from education and training institutions and public entities is valid and reliable. Its data quality assurance processes are, therefore, being improved continuously.

The Department uses the racial descriptors: "African", "Coloured", "White" and "Indian/Asian" for planning, monitoring and funding purposes. The Department places on record that these racial descriptors, which characterised apartheid policies and practices in the past, are being used to provide historical context and comparisons as well as to describe and measure the effects of present policy and practice on redressing the inequities of the past as required by the Constitution of South Africa. 


\section{THE PROVISIONING OF POST-SCHOOL EDUCATION AND TRAINING (PSET): A STATISTICAL OVERVIEW}

The formal provisioning of PSET in South Africa occurs mainly through three main types of public and private education and training institutions, namely: Higher Education Institutions (HEls); Further Education and Training/Technical and Vocational Education and Training (FET/TVET) Colleges and Adult Education and Training (AET) Centres. In addition, workplace-based education and training occurs through a range of learning programmes that are supported and facilitated through Sector Education and Training Authorities (SETAs).

This section of the report provides a statistical overview of public and private PSET institutions, enrolment in these institutions and information on the number of persons participating in workplace-based programmes.

Table 1: Overview of PSET institutions, in 2013

\begin{tabular}{|c|c|c|c|c|c|c|c|c|c|c|}
\hline & \multicolumn{3}{|c|}{ HEIS } & \multicolumn{3}{|c|}{ FET Colleges } & \multicolumn{3}{|c|}{ AET Centres } & \multirow{2}{*}{$\begin{array}{l}\text { TOTAL } \\
\text { PSET }\end{array}$} \\
\hline & Public & Private & Total & Public & Private & Total & Public & Private & Total & \\
\hline Number of institutions & 23 & 113 & 136 & 50 & 627 & 677 & 3150 & 62 & 3212 & 4025 \\
\hline $\begin{array}{l}\text { Number of } \\
\text { students/learners enrolled }\end{array}$ & 983698 & 119941 & 1103639 & 639618 & 154632 & 794250 & 249507 & 8316 & 257823 & 2155712 \\
\hline
\end{tabular}

Sources:

Public Higher Education Institutions: 2013 HEMIS database, extracted in October 2013.

Private Higher Education Institutions: Annual Reports submitted by private HEIs to the DHET, April 2013.

2013 Annual Survey of Public FET Colleges 20140807.

2013 Annual Survey of Private FET Colleges 20140726.

2013 Annual Survey of AET Centres 20140908.

Note 1: Private Higher Education (HE) figures are unaudited.

Note 2: The number of private FET Colleges shown in Table 1 reflect the number of Colleges registered with the Department.

Note 3: The number of private AET Centres shown in Table 1 reflect the number of Centres that registered with the Department.

As Table 1 indicates, more than two million students and learners were enrolled in over 4000 PSET institutions in South Africa in 2013.

The Higher Education (HE) sector comprised 136 public and private institutions in 2013, reflecting an increase of six private institutions since 2012. Twenty-three of the institutions were public and 113 private. These institutions serviced almost 990000 and 120000 students, respectively. As evident from student enrolment figures, the public HE sector is considerably larger than the private sector, with $89 \%$ of student enrolment located in the public sector.

The FET/TVET sector comprised almost 680 public FET/TVET and private FET Colleges in 2013, of which 50 were public and 627 private. Although the number of private (registered) FET Colleges far exceeded that of public FET/TVET Colleges, student enrolment in private FET Colleges comprised $19 \%$ of total student enrolment in the FET/TVET College sector.

The AET sector comprised over 3200 public and private AET Centres in 2013. As is evident from student enrolment figures in AET Centres, the private AET sector in South Africa is relatively small. 
Figure 1: Percentage distribution of student enrolment in PSET institutions, in 2013

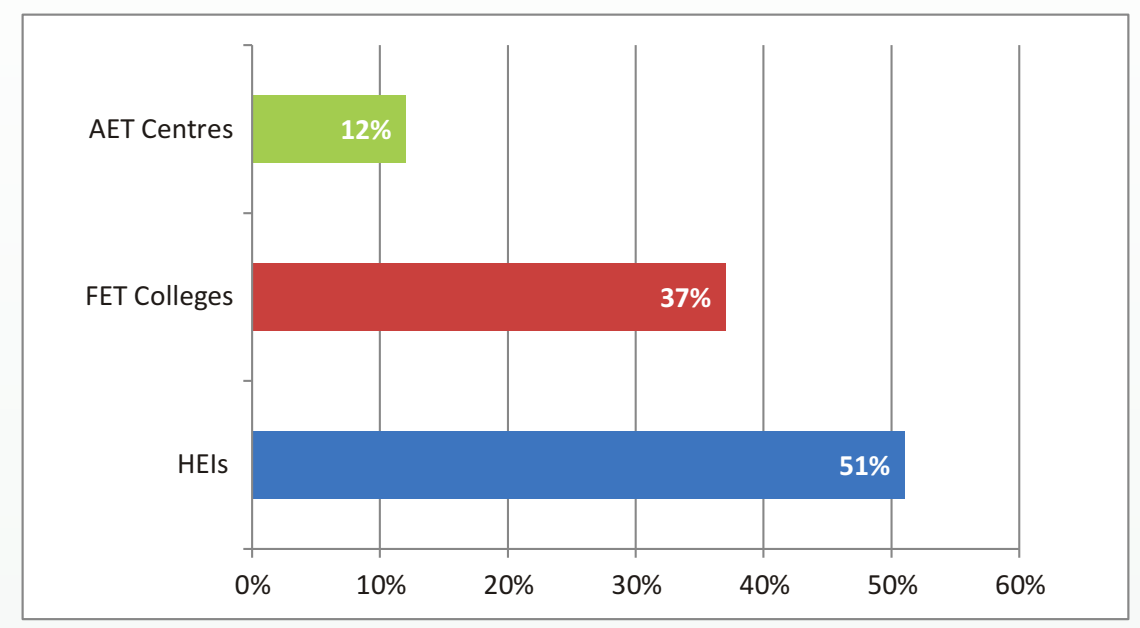

Note: Figure 1 reflects enrolment in both public and private institutions.

As indicated in Figure 1, more than half of all students enrolled in PSET institutions were enrolled in the HE sector, while $37 \%$ were enrolled in the FET/TVET College sector and $12 \%$ in the AET sector. Compared with 2012, this distribution increased by two percentage points for HEls, decreased by a percentage point for FET/TVET Colleges and decreased by three percentage points for AET Centres.

Table 2: Number of workers and unemployed persons registered for and certificated in SETA-supported learning programmes, by programme type, in 2013
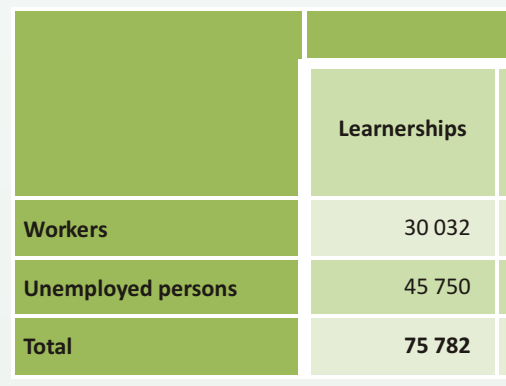

\begin{tabular}{|r|}
\hline \multicolumn{2}{|c|}{ Registered } \\
\hline Internships \\
\hline n.a \\
\hline 8017 \\
\hline $\mathbf{8 0 1 7}$ \\
\hline
\end{tabular}

\begin{tabular}{|r|r|}
\hline $\begin{array}{c}\text { Skills } \\
\text { Development } \\
\text { Programmes }\end{array}$ & Total \\
\hline 74132 & 104155 \\
\hline 18376 & $\mathbf{7 2 1 4 3}$ \\
\hline 92508 & 176298 \\
\hline
\end{tabular}

\begin{tabular}{|r|r|r|r|}
\hline \multicolumn{4}{|c|}{ Certificated } \\
\hline Learnerships & Internships & $\begin{array}{c}\text { Skills } \\
\text { Development } \\
\text { Programmes }\end{array}$ & Total \\
\hline 14973 & n.a & 90694 & 105667 \\
\hline 23823 & 2510 & 18853 & 45186 \\
\hline 38796 & 2510 & 109547 & 150853 \\
\hline
\end{tabular}

Source: SETA Quarterly Reports, 2013/14.

Note 1: The category "Learnerships" means a learning programme that leads to an occupational qualification or part-qualification and includes an apprenticeship and cadetship.

Note 2: The category "Internships" refers to the structured work experience component of an occupational qualification registered by the Quality Council for Trades and Occupations (QCTO).

Note 3: The category "Skills Development Programmes" refers to programmes that have been undertaken as part-qualifications as defined in the National Qualifications Framework (NQF)Act, 2008, (Act No.67 of 2008).

Note 4: "n.a." means not applicable.

SETAs registered more than 176000 learners in SETA-supported learning programmes and certificated approximately 151000 learners in 2013. More than 75000 learners registered for learnership programmes and 92500 learners registered for Skills Development Programmes during this period.

A greater proportion of unemployed persons registered for learnerships (45 750) compared with those registered for Skills Development Programmes (18376). 


\section{HIGHER EDUCATION AND TRAINING}

\subsection{ENROLMENT IN PUBLIC AND PRIVATE HIGHER EDUCATION INSTITUTIONS (HEIs)}

In 2013, the Higher Education (HE) sector comprised 23 public HEls and 113 private HEls, with over 85\% of all HE students enrolled in public HEls. The Department of Higher Education and Training (DHET) established two new public HEIs in 2014.

Figure 2: Number of students enrolled in public and private HEls, from 2009 to 2013

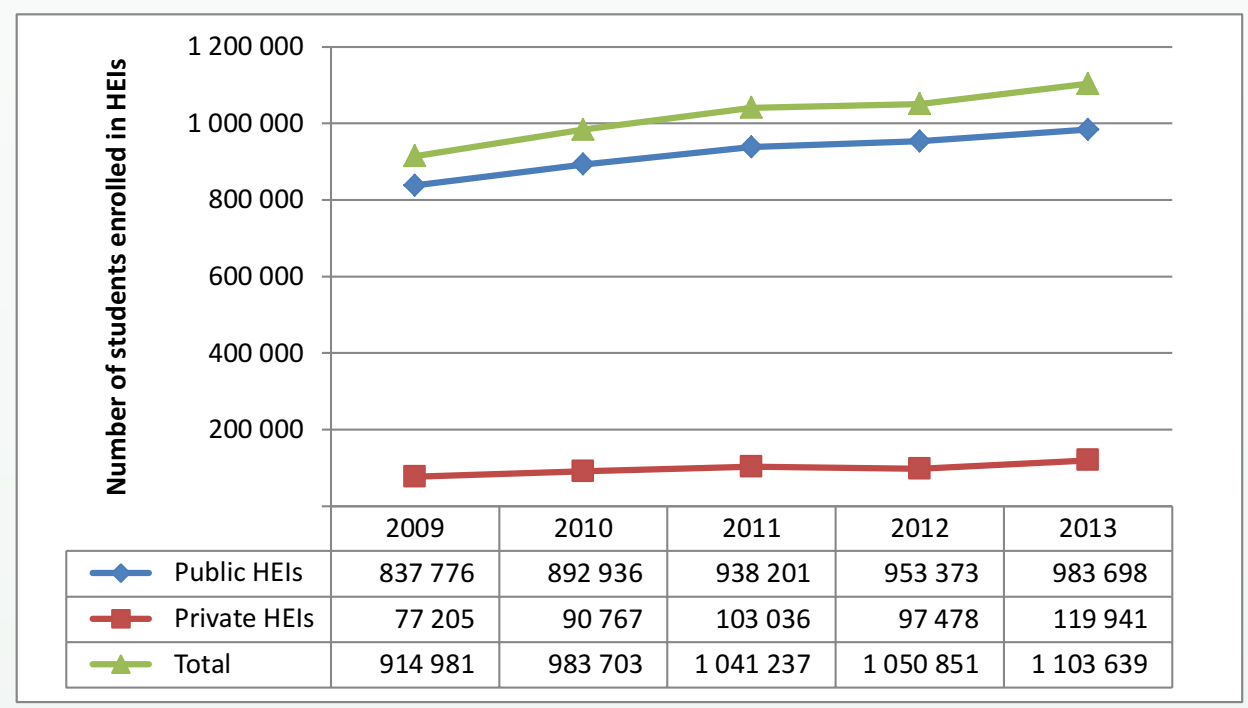

Sources:

2013 HEMIS database, data extracted in October 2014.

2013 Annual Reports submitted to the DHET by private HEIs.

Note: Enrolment figures for private HEls are unaudited.

The total student enrolment in HEls (both public and private) increased from about 915000 in 2009 to more than 1.1 million in 2013. Plans are afoot to ensure that government's enrolment target of 1620000 for public HEls, as expressed in the National Development Plan (NDP) ${ }^{1}$, is achieved by 2030.

Close to 146000 more students enrolled in public HEls in 2013 compared with the figure in 2009, while the number of students enrolled in private HEls increased by about 43000 from 2009 to 2013.

${ }^{1}$ The Presidency (2011). National Development Plan: Vision 2030, Pretoria. 


\subsection{PUBLIC HEIS}

\subsubsection{Introduction}

Of the 23 public HEls that existed in South Africa in 2013, 11 were generally regarded as "traditional" Universities, six were Universities of Technology (formerly known as Technikons) and six were Comprehensive Universities (established from the merger of traditional Universities and former Technikons). Since 2013, two new public HEls, Sol Plaatje University in the Northern Cape and the University of Mpumalanga in Mpumalanga, started operations in 2014.

The statistics reflected in the tables and figures below were provided to the Department by public HEls. The figures can be considered to be fairly reliable since external auditors appointed by HEls audited the data prior to it being submitted to the Department.

\subsubsection{Enrolment in public HEls}

Figure 3: Number of students enrolled in public HEls, by attendance mode, from 2009 to 2013

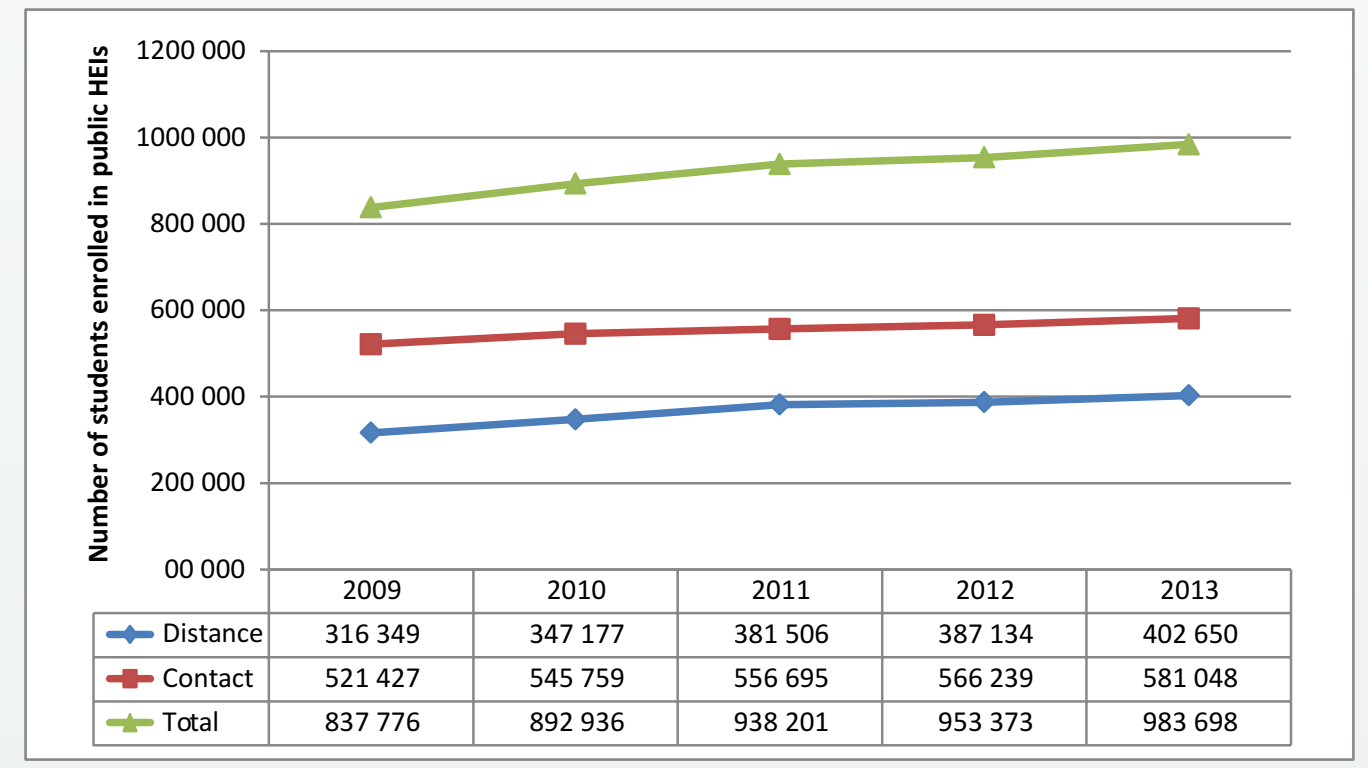

Source: 2013 HEMIS database, extracted in October 2014.

Note 1: The contact mode of study involves personal interaction with lecturers or supervisors through, inter alia, lectures, seminars and/or practicals on the premises of institutions.

Note 2: The distance mode of study involves interaction with lecturers or supervisors through distance education techniques, such as written correspondence, telematics and/or the Internet.

Figure 3 shows that in 2013, a significantly higher number of students in public HEls (581 048) were enrolled for the contact mode of study compared with those enrolled for the distance mode of learning (402650). 
Table 3: Number of first-time undergraduate students enrolled in public HEls, by institution, from 2009 to 2013

\begin{tabular}{|l|l|}
\hline Institution \\
\hline Cape Peninsula University of Technology \\
\hline University of Cape Town \\
\hline Central University of Technology, Free State \\
\hline Durban University of Technology \\
\hline University of Fort Hare \\
\hline University of the Free State \\
\hline University of Johannesburg \\
\hline University of KwaZulu-Natal \\
\hline University of Limpopo \\
\hline Mangosuthu University of Technology \\
\hline Nelson Mandela Metropolitan University \\
\hline North West University \\
\hline University of Pretoria \\
\hline Rhodes University \\
\hline University of South Africa \\
\hline University of Stellenbosch \\
\hline Tshwane University of Technology \\
\hline University of Venda \\
\hline Vaal University of Technology \\
\hline Walter Sisulu University \\
\hline University of Western Cape \\
\hline University of Witwatersrand \\
\hline University of Zululand \\
\hline Total \\
\hline
\end{tabular}

\begin{tabular}{|c|c|c|c|c|}
\hline 2009 & 2010 & 2011 & 2012 & 2013 \\
\hline 8244 & 8106 & 7876 & 7949 & 7604 \\
\hline 4153 & 3637 & 3464 & 3875 & 3748 \\
\hline 3941 & 3321 & 2722 & 2803 & 3408 \\
\hline 6856 & 7096 & 6243 & 6078 & 6842 \\
\hline 2314 & 2468 & 2592 & 2811 & 2276 \\
\hline 4038 & 5007 & 5829 & 6202 & 5533 \\
\hline 13168 & 10230 & 12404 & 10181 & 10142 \\
\hline 8048 & 8053 & 7649 & 7150 & 8684 \\
\hline 3421 & 4745 & 5288 & 5137 & 4861 \\
\hline 3032 & 2769 & 2510 & 2840 & 2883 \\
\hline 5391 & 5099 & 5815 & 5164 & 5226 \\
\hline 5929 & 7206 & 7526 & 7848 & 8770 \\
\hline 8015 & 8124 & 7408 & 7412 & 8497 \\
\hline 1670 & 1451 & 1230 & 1275 & 1372 \\
\hline 40884 & 47208 & 60912 & 52227 & 33828 \\
\hline 4234 & 4599 & 4535 & 3936 & 4553 \\
\hline 12760 & 11621 & 10556 & 12184 & 13593 \\
\hline 1796 & 1680 & 1975 & 2176 & 3457 \\
\hline 5956 & 6073 & 4816 & 4412 & 4010 \\
\hline 6082 & 6078 & 5742 & 5214 & 5956 \\
\hline 3251 & 3783 & 3852 & 3871 & 3896 \\
\hline 6590 & 5300 & 4684 & 5349 & 5418 \\
\hline 4745 & 4734 & 3477 & 3671 & 3832 \\
\hline 164518 & 168388 & 179105 & 169765 & 158389 \\
\hline
\end{tabular}

Source: 2013 HEMIS database, extracted in October 2014.

Note: A first-time entering undergraduate student is defined as a person who is (a) registered for an undergraduate or prediplomate course, and (b) has not registered at any $\mathrm{HEl}$ in the past.

Table 3 shows that the total number of undergraduate students who entered public HEls for the first time decreased from about 165000 students in 2009 to 158000 in 2013. The pattern in the number of enrolments has been uneven over the past five years, with the number of new undergraduate enrolments peaking to more than 179000 in 2011, and then dropping in 2012 and 2013. The decline has mainly been evident since 2012. The University of South Africa (UNISA) had the most significant decline in first-time entrants over the past two years, from 52000 students in 2012, to almost 34000 in 2013. 
Table 4: Number of students enrolled in public HEls, by major field of study, qualification type and institution, in 2013

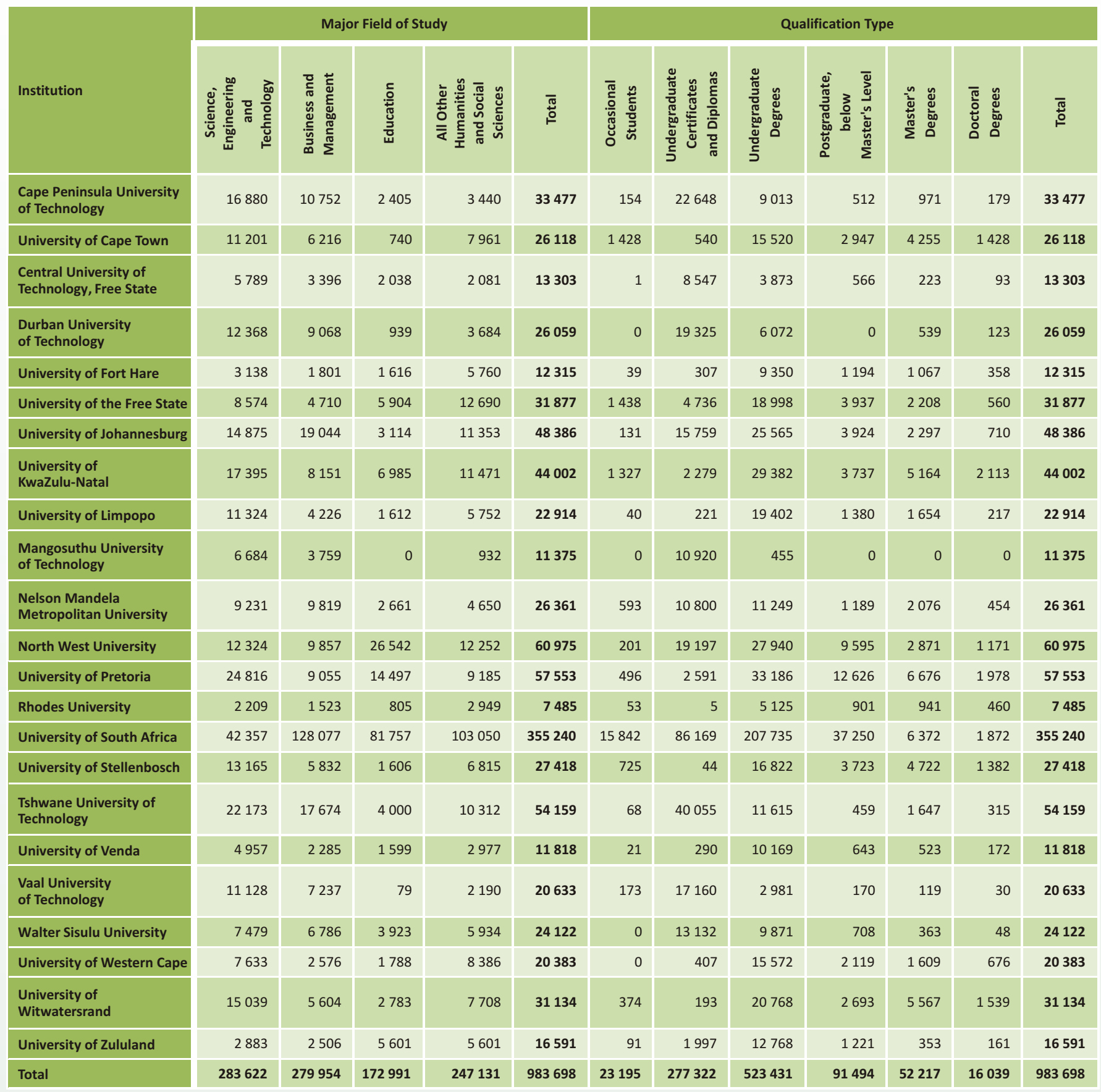

\section{Source: 2013 HEMIS database, extracted in October 2014.}

Note 1: SET majors mean majors in Science, Engineering and Technology. These include majors in Engineering, Health Sciences, Life Sciences, Physical Sciences, Computer Sciences and Mathematical Sciences.

Note 2: Business majors include majors in Accounting, Management and all other business-related majors, such as Marketing.

Note 3: Humanities majors include majors in Education, Languages and Literary Studies, Fine Arts, Music and the Social Sciences.

Note 4: Occasional students are students who are taking courses that are part of formally approved programmes, but who are not registered for a formal Degree or Diploma.

Note 5: The category "Undergraduate Degrees" includes professional Bachelor's Degrees, which are those that have an approved formal time of four or more years. Examples include Degrees such as B Tech, BSc (Engineering), MB ChB and BFA.

Note 6: The category "Postgraduate, below Master's Level" includes Postgraduate and Post-Diploma Diplomas, Postgraduate Bachelor's Degrees, and Honours Degrees.

Note 7: As a result of rounding off, numbers and percentages may not necessarily add up.

Note 8: Since some students were coded as "major field of study unknown", totals may not add up. 
Table 4 shows that in public HEls in 2013, student enrolment was highest in the field of Humanities (Education plus all other Humanities and Social Sciences), with close to 420122 students enrolled in this field, followed by about 284000 students in the field of Science Engineering and Technology (SET) and close to 280000 students in the field of Business and Management. As Table 4 shows, close to 173000 students in public HEls enrolled in the Education field of study in 2013.

Table 4 also shows that in 2013, the highest proportion of students in public HEls were registered in Undergraduate Degree programmes (523 431), followed by Undergraduate Certificate and Diploma programmes (277 322), Postgraduate below Master's Level (91 494), Master's Degrees (52 217), occasional students (23 195) and Doctoral Degrees (16039).

Figure 4: Number of students enrolled in public HEls, by major field of study, from 2011 to 2013

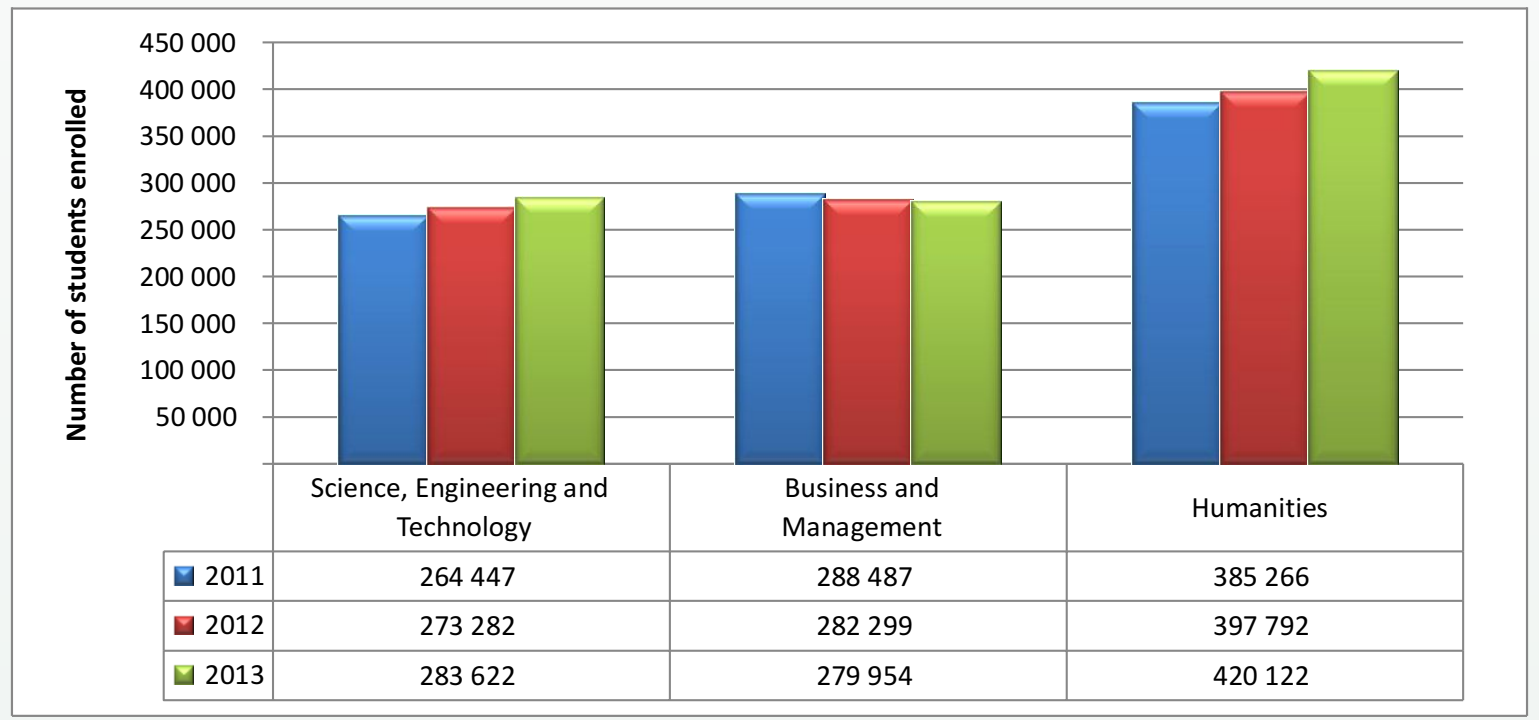

Source: 2013 HEMIS database, extracted in October 2014.

Figure 4 shows that the number of students enrolled in the SET and Humanities fields of study in public HEls increased steadily from 2011 to 2013, while that in the field of Business and Management decreased over the same period. The student enrolment ratio between the SET; Business and Management; and Humanities major fields of study stood at $29 \%, 28 \%$ and $43 \%$, respectively, in 2013. 
Figure 5: Percentage distribution of student enrolment in public HEls, by qualification type, in 2013

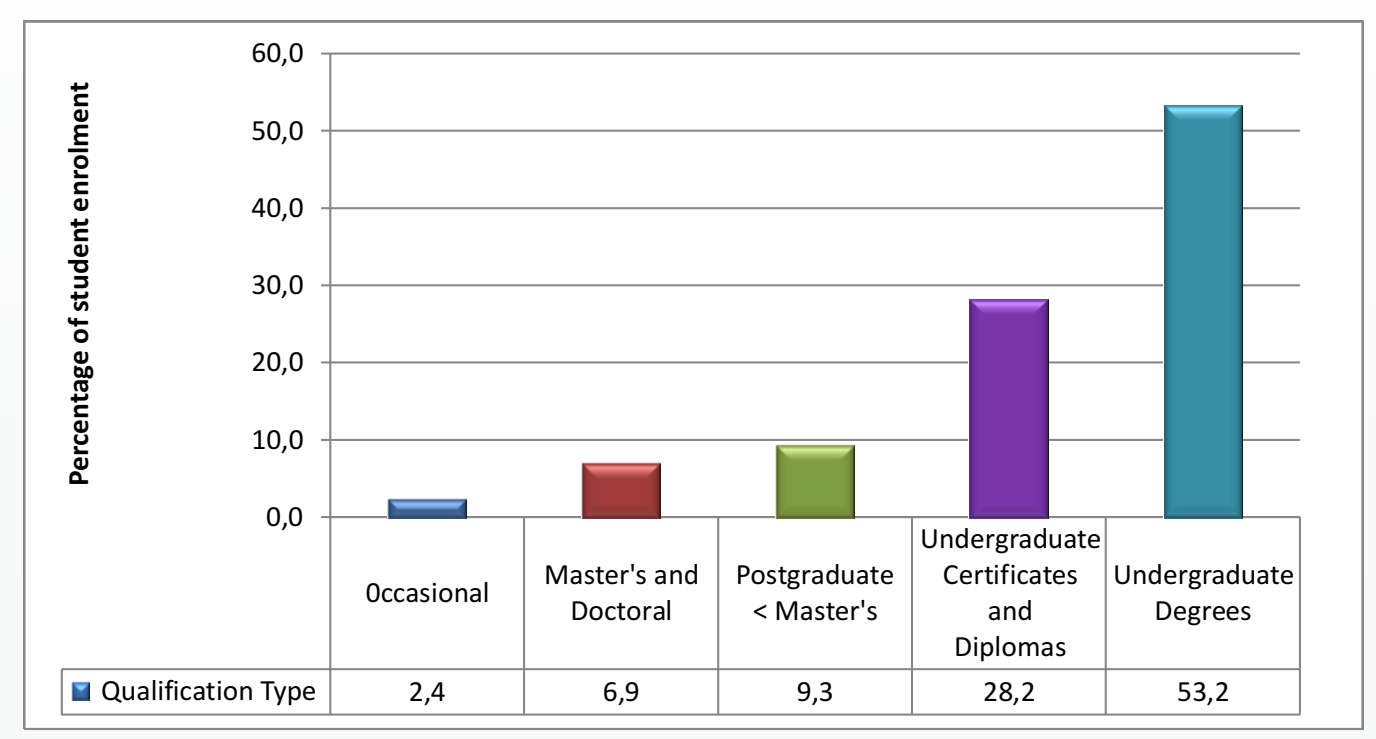

Source: 2013 HEMIS database, extracted in October 2014.

Note: As a result of rounding off, percentages may not necessarily add up.

Figure 5 shows that the percentage of students enrolled in Undergraduate Degree programmes in public HEls constituted $53 \%$ of total enrolment in 2013 , followed by students who registered for Undergraduate Certificate and Diploma programmes at $28 \%$. About $7 \%$ of all students in public HEls enrolled for Master's and Doctoral programmes in 2013, while $9 \%$ of students were enrolled for Postgraduate programmes below Masters' level. 
Table 5: Number of students enrolled in public HEls, by attendance mode, population group, gender and institution, in 2013

\begin{tabular}{|c|c|c|c|c|c|c|c|c|c|c|c|c|c|c|}
\hline \multirow[b]{2}{*}{ Institution } & \multicolumn{7}{|c|}{ Contact } & \multicolumn{7}{|c|}{ Distance } \\
\hline & & 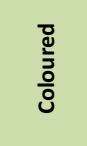 & 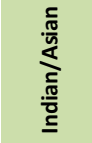 & 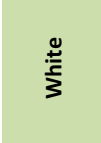 & సँّ & 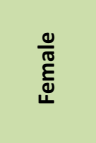 & $\frac{0}{\sum^{\pi}}$ & 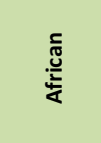 & $\begin{array}{l}\text { वृ } \\
\frac{1}{\grave{3}} \\
\text { 응 }\end{array}$ & 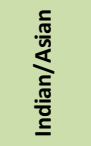 & 壱 & 完 & 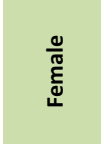 & $\sum^{\frac{0}{\pi}}$ \\
\hline $\begin{array}{l}\text { Cape Peninsula University } \\
\text { of Technology }\end{array}$ & 19235 & 9367 & 396 & 4372 & 33370 & 17940 & 15430 & 44 & 7 & 3 & 53 & 107 & 38 & 69 \\
\hline University of Cape Town & 6979 & 3628 & 1802 & 8589 & 26109 & 13709 & 12400 & 0 & 0 & 0 & 0 & 0 & 0 & 0 \\
\hline $\begin{array}{l}\text { Central University of } \\
\text { Technology, Free State }\end{array}$ & 11411 & 434 & 42 & 1163 & 13050 & 6120 & 6930 & 177 & 68 & 2 & 6 & 253 & 187 & 66 \\
\hline $\begin{array}{l}\text { Durban University } \\
\text { of Technology }\end{array}$ & 21053 & 415 & 3732 & 827 & 26059 & 12658 & 13401 & 0 & 0 & 0 & 0 & 0 & 0 & 0 \\
\hline University of Fort Hare & 11714 & 229 & 45 & 327 & 12315 & 7004 & 5311 & 0 & 0 & 0 & 0 & 0 & 0 & 0 \\
\hline University of Johannesburg & 38648 & 1500 & 2195 & 6043 & 48386 & 25998 & 22388 & 0 & 0 & 0 & 0 & 0 & 0 & 0 \\
\hline $\begin{array}{l}\text { University of } \\
\text { KwaZulu-Natal }\end{array}$ & 26055 & 906 & 10674 & 2796 & 40576 & 23064 & 17512 & 3225 & 32 & 129 & 36 & 3426 & 2666 & 760 \\
\hline University of Limpopo & 22478 & 26 & 132 & 278 & 22914 & 12405 & 10509 & 0 & 0 & 0 & 0 & 0 & 0 & 0 \\
\hline $\begin{array}{l}\text { Mangosuthu University } \\
\text { of Technology }\end{array}$ & 11340 & 16 & 14 & 5 & 11375 & 5715 & 5660 & 0 & 0 & 0 & 0 & 0 & 0 & 0 \\
\hline $\begin{array}{l}\text { Nelson Mandela } \\
\text { Metropolitan University }\end{array}$ & 14941 & 3634 & 319 & 6407 & 25301 & 13300 & 12001 & 992 & 56 & 0 & 12 & 1060 & 863 & 197 \\
\hline North West University & 18176 & 1143 & 441 & 16434 & 36195 & 21422 & 14773 & 21347 & 1541 & 44 & 808 & 24780 & 19351 & 5429 \\
\hline University of Pretoria & 20038 & 1069 & 2269 & 24089 & 47468 & 26075 & 21393 & 9900 & 59 & 44 & 82 & 10085 & 7263 & 2822 \\
\hline Rhodes University & 4046 & 280 & 303 & 2856 & 7485 & 4356 & 3129 & 0 & 0 & 0 & 0 & 0 & 0 & 0 \\
\hline University of South Africa & 0 & 0 & 0 & 0 & 0 & 0 & 0 & 253613 & 19105 & 24401 & 57268 & 355238 & 223603 & 131635 \\
\hline University of Venda & 11797 & 3 & 11 & 7 & 11818 & 6438 & 5380 & 0 & 0 & 0 & 0 & 0 & 0 & 0 \\
\hline $\begin{array}{l}\text { Vaal University } \\
\text { of Technology }\end{array}$ & 19647 & 268 & 72 & 508 & 20495 & 9364 & 11131 & 138 & 0 & 0 & 0 & 138 & 60 & 78 \\
\hline Walter Sisulu University & 23970 & 37 & 72 & 43 & 24122 & 13157 & 10965 & 0 & 0 & 0 & 0 & 0 & 0 & 0 \\
\hline University of Western Cape & 8653 & 9431 & 1051 & 1021 & 20382 & 12171 & 8211 & 0 & 0 & 0 & 0 & 0 & 0 & 0 \\
\hline $\begin{array}{l}\text { University of } \\
\text { Witwatersrand }\end{array}$ & 18210 & 1157 & 4076 & 7669 & 31134 & 17026 & 14108 & 0 & 0 & 0 & 0 & 0 & 0 & 0 \\
\hline University of Zululand & 16466 & 26 & 55 & 44 & 16591 & 10397 & 6194 & 0 & 0 & 0 & 0 & 0 & 0 & 0 \\
\hline Total & 394238 & 39638 & 28857 & 112765 & 581038 & 314679 & 266359 & 295265 & 21396 & 24930 & 59162 & 402648 & 259019 & 143629 \\
\hline Percentage & 68 & 7 & 5 & 19 & 100 & 54 & 46 & 73 & 5 & 6 & 15 & 100 & 64 & 36 \\
\hline
\end{tabular}

Source: 2013 HEMIS database, extracted in October 2014.

Note 1: Contact students are those who are registered mainly for courses offered in contact mode.

Note 2: Distance students are those who are registered mainly for courses offered in distance mode.

Note 3: The figures in the "total" columns are for both gender and population group. Given that students coded as "race unknown" are not included in the table, the sum of African + Coloured + Indian/Asian + White students may not be accurately reflected in the "total" columns.

Note 4: As a result of rounding off, numbers and percentages may not necessarily add up.

Table 5 shows that in 2013, African students comprised $68 \%$ of all students in public HEls studying through the contact mode of study, and $73 \%$ of all students studying through the distance mode of education. White, Coloured and Indian/Asian students made up 19\%, 7\% and 5\%, respectively, of all students enrolled in public HEls for the contact mode of study in 2013. In general, a higher proportion of African and Indian/Asian students enrolled for distance mode programmes rather than the contact mode of education in 2013. 
Table 5 also shows that females comprised $54 \%$ of all students enrolled in public HEls for the contact mode of study and $64 \%$ of students enrolled through distance learning programmes in 2013.

Figure 6: Percentage distribution of student enrolment in public HEIs, by attendance mode and gender, in 2013

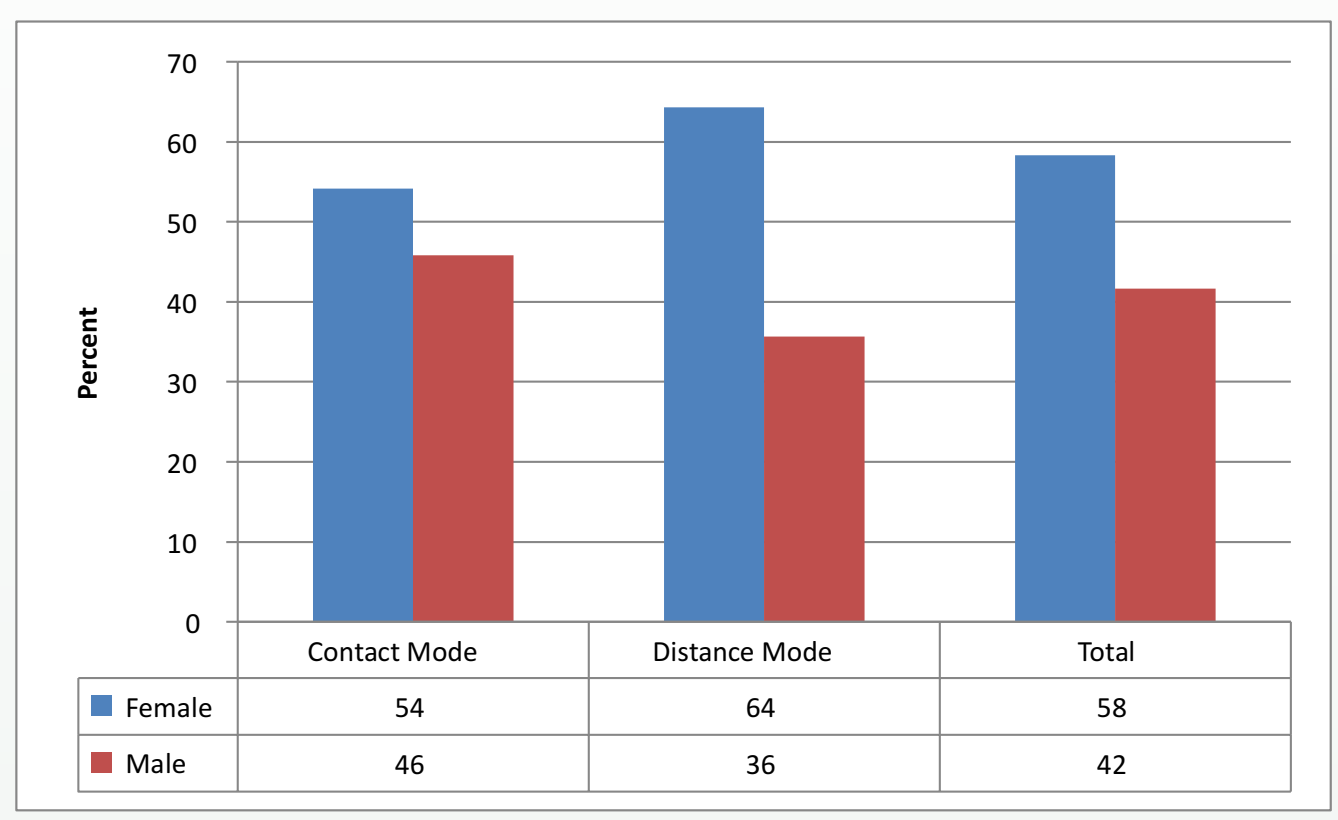

Source: 2013 HEMIS database, extracted in October 2014.

Figure 6 shows that females comprised $58 \%$ of total student enrolment in public HEls compared with $42 \%$ males in 2013. It also indicates a higher proportion of females enrolled for contact programmes compared with males. 
Table 6: Number of foreign students enrolled in public HEls, by country, attendance mode and qualification type, in 2013

\begin{tabular}{|c|c|c|c|c|c|c|c|c|c|c|c|c|c|c|c|}
\hline \multirow[b]{2}{*}{ Country } & \multicolumn{7}{|c|}{ Contact } & \multicolumn{7}{|c|}{ Distance } & \multirow[b]{2}{*}{ 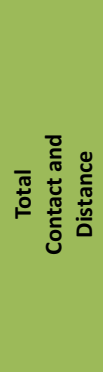 } \\
\hline & 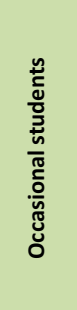 & 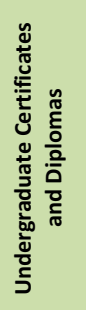 & 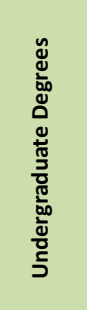 & 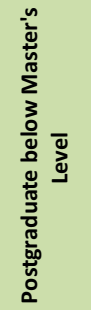 & 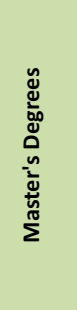 & 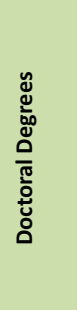 & 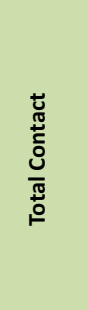 & 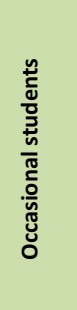 & 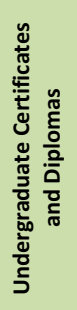 & 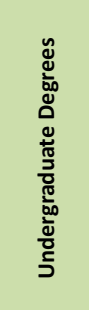 & 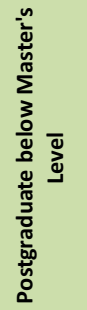 & 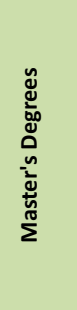 & 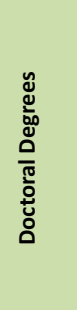 & 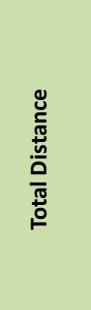 & \\
\hline Zimbabwe & 69 & 801 & 5959 & 1155 & 1852 & 1053 & 10889 & 438 & 1035 & 11925 & 1859 & 529 & 247 & 16033 & 26922 \\
\hline Namibia & 35 & 353 & 1290 & 372 & 484 & 105 & 2639 & 90 & 1045 & 873 & 601 & 88 & 16 & 2713 & 5352 \\
\hline Lesotho & 63 & 561 & 969 & 402 & 421 & 127 & 2543 & 77 & 1279 & 490 & 447 & 44 & 12 & 2349 & 4892 \\
\hline Swaziland & 10 & 706 & 1022 & 101 & 268 & 92 & 2199 & 109 & 322 & 995 & 594 & 101 & 10 & 2131 & 4330 \\
\hline $\begin{array}{l}\text { Democratic Republic } \\
\text { of the Congo }\end{array}$ & 15 & 1659 & 590 & 87 & 229 & 68 & 2648 & 31 & 201 & 339 & 54 & 42 & 23 & 690 & 3338 \\
\hline Botswana & 11 & 154 & 742 & 157 & 290 & 108 & 1462 & 82 & 209 & 1230 & 79 & 55 & 14 & 1669 & 3131 \\
\hline Zambia & 8 & 75 & 393 & 86 & 327 & 135 & 1024 & 18 & 61 & 642 & 57 & 39 & 26 & 843 & 1867 \\
\hline Kenya & 9 & 39 & 308 & 79 & 308 & 330 & 1073 & 17 & 21 & 389 & 34 & 90 & 40 & 591 & 1664 \\
\hline $\begin{array}{l}\text { United States of } \\
\text { America }\end{array}$ & 915 & 3 & 51 & 24 & 133 & 134 & 1260 & 3 & 2 & 38 & 10 & 10 & 65 & 128 & 1388 \\
\hline $\begin{array}{l}\text { Other } \\
\text { countries }\end{array}$ & 1188 & 1782 & 3654 & 874 & 2789 & 1942 & 12229 & 237 & 597 & 2885 & 609 & 477 & 552 & 5357 & 17586 \\
\hline Total & 2337 & 6326 & 15299 & 3545 & 7847 & 4856 & 40210 & 1154 & 4862 & 20514 & 4483 & 1566 & 1067 & 33646 & 73856 \\
\hline
\end{tabular}

Source: 2013 HEMIS database, extracted in October 2014.

Note 1: Contact students are those who are registered mainly for courses offered in contact mode.

Note 2: Distance students are those who are registered mainly for courses offered in distance mode.

Note 3: Occasional students are students who are taking courses that are part of formally approved programmes, but who are not registered for a formal Degree or Diploma.

Note 4: The category "Undergraduate Degrees" also includes professional Bachelor's Degrees, which are those that have an approved formal time of four or more years Examples include Degrees such as B Tech, BSc (Engineering), MB ChB and BFA.

Note 5: The category "Postgraduate, below Master's Level" includes Postgraduate and Post-Diploma Diplomas, Postgraduate Bachelor's Degrees and Honours Degrees.

Note 6: Enrolment numbers are listed for the ten countries with the highest foreign student enrolment. The rest of foreign student enrolments are included in "other countries".

Table 6 shows that close to 74000 students from countries outside South Africa enrolled in public HEls in 2013. The majority of these students were from the African continent. Zimbabweans constituted the highest number of foreign student enrolments in both contact (approximately 11000 ) and distance mode (16 000) of attendance. The majority of foreign students were studying towards an Undergraduate Degree, although a significant number were enrolled for Doctorate programmes. 
Table 7: Full-Time Equivalent (FTE) student enrolment in public HEls, by attendance mode, major field of study and institution, in 2013

\begin{tabular}{|c|c|c|c|c|c|c|c|c|c|c|}
\hline \multirow[b]{2}{*}{ Institution } & \multicolumn{5}{|c|}{ Contact } & \multicolumn{5}{|c|}{ Distance } \\
\hline & 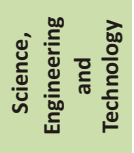 & 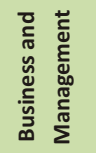 & 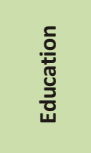 & 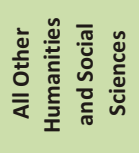 & 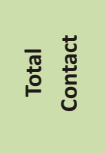 & 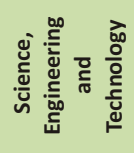 & 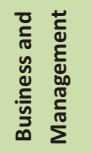 & 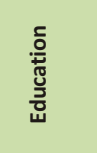 & 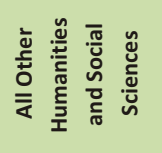 & 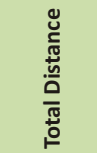 \\
\hline University of Cape Town & 8348 & 4686 & 468 & 6539 & 20042 & 0 & 0 & 0 & 0 & 0 \\
\hline $\begin{array}{l}\text { Central University of } \\
\text { Technology, Free State }\end{array}$ & 4068 & 2062 & 1890 & 1770 & 9789 & 13 & 69 & 0 & 91 & 173 \\
\hline $\begin{array}{l}\text { Durban University of } \\
\text { Technology }\end{array}$ & 8435 & 5806 & 645 & 4352 & 19237 & 0 & 0 & 0 & 0 & 0 \\
\hline University of Fort Hare & 2556 & 1519 & 1584 & 4646 & 10305 & 0 & 0 & 0 & 0 & 0 \\
\hline University of the Free State & 7174 & 3419 & 2349 & 7132 & 20074 & 22 & 758 & 1743 & 865 & 3387 \\
\hline University of Johannesburg & 10347 & 13896 & 2676 & 9828 & 36747 & 0 & 0 & 0 & 0 & 0 \\
\hline University of KwaZulu-Natal & 12288 & 5712 & 4473 & 9320 & 31793 & 534 & 0 & 970 & 0 & 1504 \\
\hline University of Limpopo & 8900 & 2521 & 2366 & 5362 & 19149 & 0 & 0 & 0 & 0 & 0 \\
\hline $\begin{array}{l}\text { Mangosuthu University of } \\
\text { Technology }\end{array}$ & 4247 & 2133 & 0 & 1364 & 7745 & 0 & 0 & 0 & 0 & 0 \\
\hline $\begin{array}{l}\text { Nelson Mandela Metropolitan } \\
\text { University }\end{array}$ & 7032 & 6141 & 1100 & 4869 & 19141 & 143 & 0 & 380 & 0 & 523 \\
\hline North West University & 9345 & 6467 & 2823 & 10864 & 29499 & 1473 & 131 & 8080 & 1851 & 11535 \\
\hline University of Pretoria & 18003 & 7068 & 3258 & 8985 & 37314 & 5 & 0 & 3683 & 0 & 3688 \\
\hline Rhodes University & 1811 & 1191 & 516 & 2646 & 6163 & 0 & 0 & 0 & 0 & 0 \\
\hline University of South Africa & 0 & 0 & 0 & 1 & 1 & 26223 & 61625 & 37986 & 71266 & 197100 \\
\hline University of Stellenbosch & 10338 & 4498 & 1303 & 5664 & 21803 & 0 & 0 & 0 & 0 & 0 \\
\hline University of Venda & 3667 & 1141 & 1146 & 3728 & 9682 & 0 & 0 & 0 & 0 & 0 \\
\hline Vaal University of Technology & 6515 & 4649 & 75 & 2384 & 13623 & 25 & 72 & 0 & 23 & 121 \\
\hline Walter Sisulu University & 6545 & 2849 & 4734 & 5534 & 19662 & 0 & 0 & 0 & 0 & 0 \\
\hline University of Western Cape & 5805 & 2073 & 1139 & 6960 & 15977 & 0 & 0 & 0 & 0 & 0 \\
\hline University of Witwatersrand & 11134 & 3769 & 1912 & 6693 & 23507 & 0 & 0 & 0 & 0 & 0 \\
\hline University of Zululand & 2453 & 2419 & 3734 & 5157 & 13764 & 0 & 0 & 0 & 0 & 0 \\
\hline Total & 172977 & 102620 & 43387 & 127612 & 446596 & 28454 & 62904 & 52842 & 75060 & 219261 \\
\hline Percentage & 39 & 23 & 10 & 29 & 100 & 13 & 29 & 24 & 34 & 100 \\
\hline
\end{tabular}

Source: 2013 HEMIS database, extracted in October 2014.

Note 1: FTE student enrolments are calculated (a) by assigning to each course a fraction representing the weighting it has in the curriculum of a qualification and (b) by multiplying the headcount enrolment of that course with this fraction.

Note 2: FTE contact students are those who are registered mainly for courses offered in contact mode.

Note 3: FTE distance students are those who are registered mainly for courses offered in distance mode.

Note 4: Definitions for fields of study employed here are the same as those employed in Table 4.

Note 5: The totals above include Undergraduate and Postgraduate courses.

Table 7 shows that the total number of FTE students in public HEls were almost 670000 in 2013. The FTEs comprised about 450000 students studying through contact attendance mode and about 220000 students studying through the distance mode of learning. 


\subsubsection{Graduates in public HEls}

Figure 7: Number of graduates in public HEls, by major field of study, from 2011 to 2013

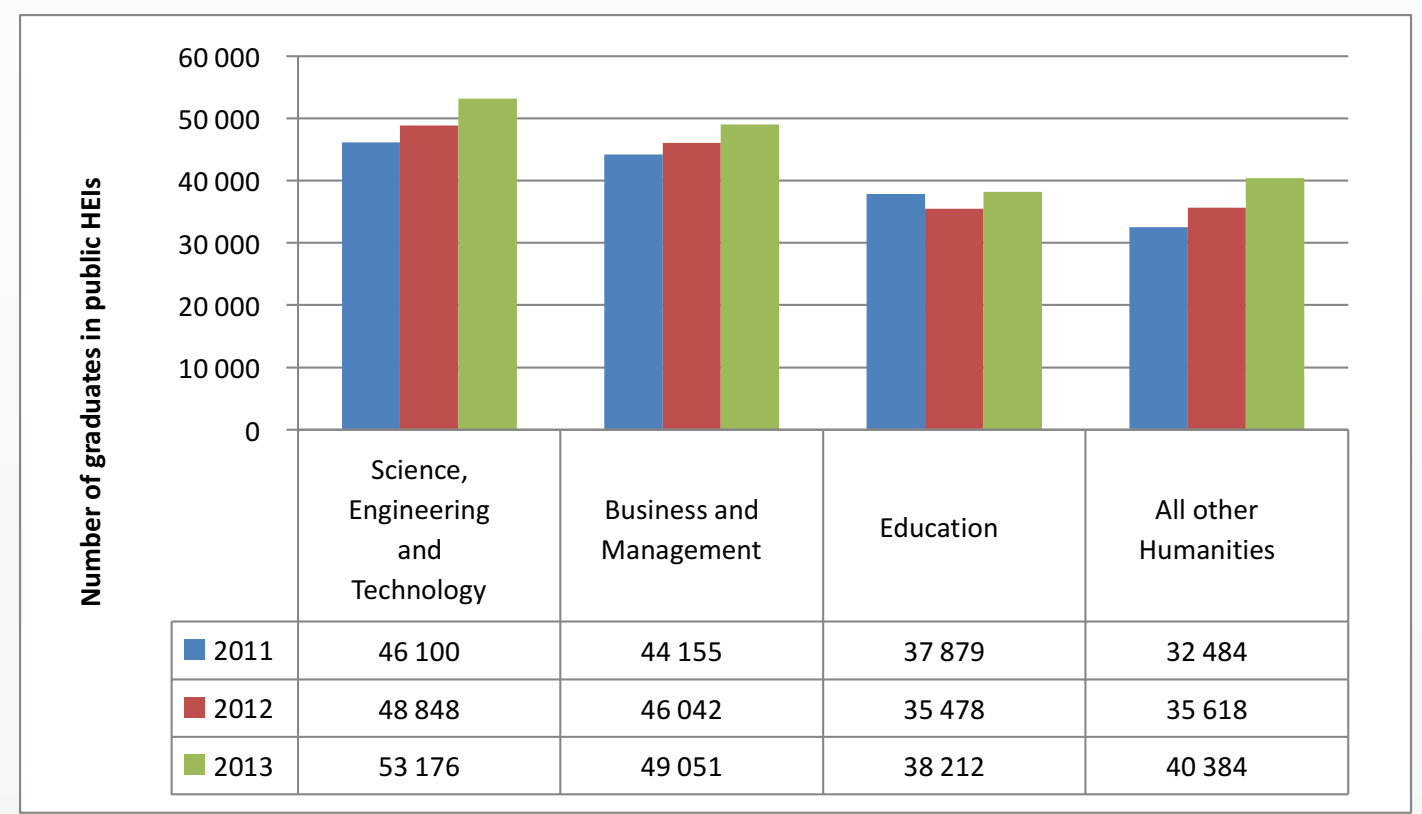

Source: 2013 HEMIS database, extracted in October 2014.

Figure 7 shows an increase in the number of graduates in all fields of study from 2011 to 2013 (with only Education indicating a small decline between 2011 and 2012). In 2013, the highest number of graduates were from the field of Humanities (Education and all other Humanities) at almost 79000 , followed by about 53000 graduates from the SET field of study. 
Table 8: Number of students who graduated from public HEls, by major field of study, qualification type and institution, in 2013

\begin{tabular}{|c|c|c|c|c|c|c|c|c|c|c|c|}
\hline \multirow[b]{2}{*}{ Institution } & \multicolumn{5}{|c|}{ Major Field of Study } & \multicolumn{6}{|c|}{ Formal Qualification } \\
\hline & 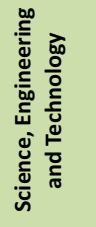 & 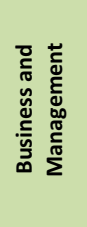 & 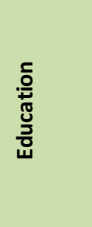 & 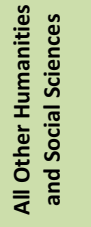 & गี & 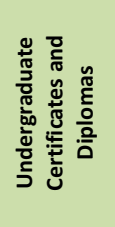 & 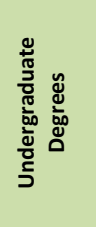 & 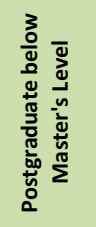 & 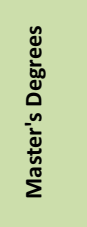 & 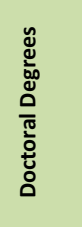 & 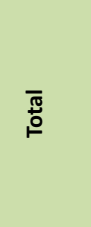 \\
\hline $\begin{array}{l}\text { Cape Peninsula University of } \\
\text { Technology }\end{array}$ & 3674 & 2827 & 823 & 839 & 8163 & 4631 & 3119 & 275 & 110 & 28 & 8163 \\
\hline University of Cape Town & 2683 & 1943 & 333 & 2043 & 7001 & 192 & 3310 & 2085 & 1209 & 205 & 7001 \\
\hline $\begin{array}{l}\text { Central University of } \\
\text { Technology, Free State }\end{array}$ & 1230 & 890 & 688 & 408 & 3217 & 1606 & 1179 & 383 & 37 & 12 & 3217 \\
\hline $\begin{array}{l}\text { Durban University of } \\
\text { Technology }\end{array}$ & 2577 & 2470 & 166 & 1165 & 6378 & 4115 & 2162 & 0 & 83 & 18 & 6378 \\
\hline University of Fort Hare & 699 & 427 & 486 & 1142 & 2754 & 126 & 1737 & 707 & 154 & 30 & 2754 \\
\hline University of the Free State & 2092 & 1080 & 1064 & 2491 & 6726 & 771 & 3264 & 2072 & 528 & 91 & 6726 \\
\hline University of Johannesburg & 3358 & 5033 & 509 & 2676 & 11576 & 3232 & 5631 & 2121 & 514 & 78 & 11576 \\
\hline University of KwaZulu -Natal & 3314 & 1996 & 2239 & 2470 & 10019 & 1117 & 5543 & 2290 & 862 & 207 & 10019 \\
\hline University of Limpopo & 1974 & 894 & 512 & 1398 & 4778 & 130 & 3305 & 1009 & 320 & 14 & 4778 \\
\hline $\begin{array}{l}\text { Mangosuthu University of } \\
\text { Technology }\end{array}$ & 1219 & 792 & 0 & 266 & 2276 & 2112 & 164 & 0 & 0 & 0 & 2276 \\
\hline $\begin{array}{l}\text { Nelson Mandela Metropolitan } \\
\text { University }\end{array}$ & 2310 & 1985 & 1050 & 950 & 6295 & 2464 & 2599 & 728 & 430 & 74 & 6295 \\
\hline North West University & 3132 & 2699 & 6756 & 2878 & 15464 & 5315 & 5624 & 3576 & 781 & 168 & 15464 \\
\hline University of Pretoria & 4859 & 2807 & 4314 & 2192 & 14172 & 1542 & 6370 & 4542 & 1476 & 242 & 14172 \\
\hline Rhodes University & 664 & 530 & 258 & 909 & 2361 & 1 & 1289 & 719 & 282 & 70 & 2361 \\
\hline $\begin{array}{l}\text { Tshwane University of } \\
\text { Technology }\end{array}$ & 4266 & 3749 & 847 & 2134 & 10996 & 7461 & 3176 & 130 & 197 & 32 & 10996 \\
\hline University of Venda & 677 & 285 & 359 & 480 & 1800 & 108 & 1342 & 310 & 37 & 3 & 1800 \\
\hline Vaal University of Technology & 1874 & 1896 & 60 & 368 & 4198 & 2801 & 1268 & 92 & 33 & 4 & 4198 \\
\hline Walter Sisulu University & 1422 & 1678 & 764 & 983 & 4846 & 2638 & 1918 & 238 & 49 & 3 & 4846 \\
\hline University of Western Cape & 1671 & 630 & 461 & 1502 & 4263 & 287 & 2385 & 1092 & 388 & 111 & 4263 \\
\hline University of Witwatersrand & 3010 & 1509 & 756 & 1899 & 7173 & 19 & 3967 & 1761 & 1205 & 221 & 7173 \\
\hline University of Zululand & 448 & 504 & 1605 & 1347 & 3904 & 739 & 2408 & 712 & 31 & 14 & 3904 \\
\hline Total & 53176 & 49051 & 38212 & 40384 & 180823 & 50914 & 79136 & 37913 & 10809 & 2051 & 180823 \\
\hline
\end{tabular}

Source: 2013 HEMIS database, extracted in October 2014.

Note 1: Definitions of fields of study are the same as those employed in Table 4.

Note 2: Definitions of formal qualifications are the same as those employed in Table 4.

Note 3: As a result of rounding off, numbers and percentages may not necessarily add up.

Note 4: Because some students were coded as "major field of study unknown", or "unknown qualification type", totals may not add up.

Table 8 shows about 181000 students graduated from public HEIs in 2013. Of these, 53178 graduated in the SET field of study, 49051 in Business and Management and 38212 in Education. The remaining 40384 graduated in the field of study "all other Humanities and Social Sciences". Table 8 also shows that, in 2013, the highest number of graduates were in Undergraduate Degree programmes (79 136), followed by Undergraduate Certificates and Diplomas (50 914), Postgraduate below Master's Level (37913), Master's Degrees (10809) and Doctoral Degrees (2051). 
Table 9: Summaries of graduation rates in public HEls, by qualification type and institution, in 2013

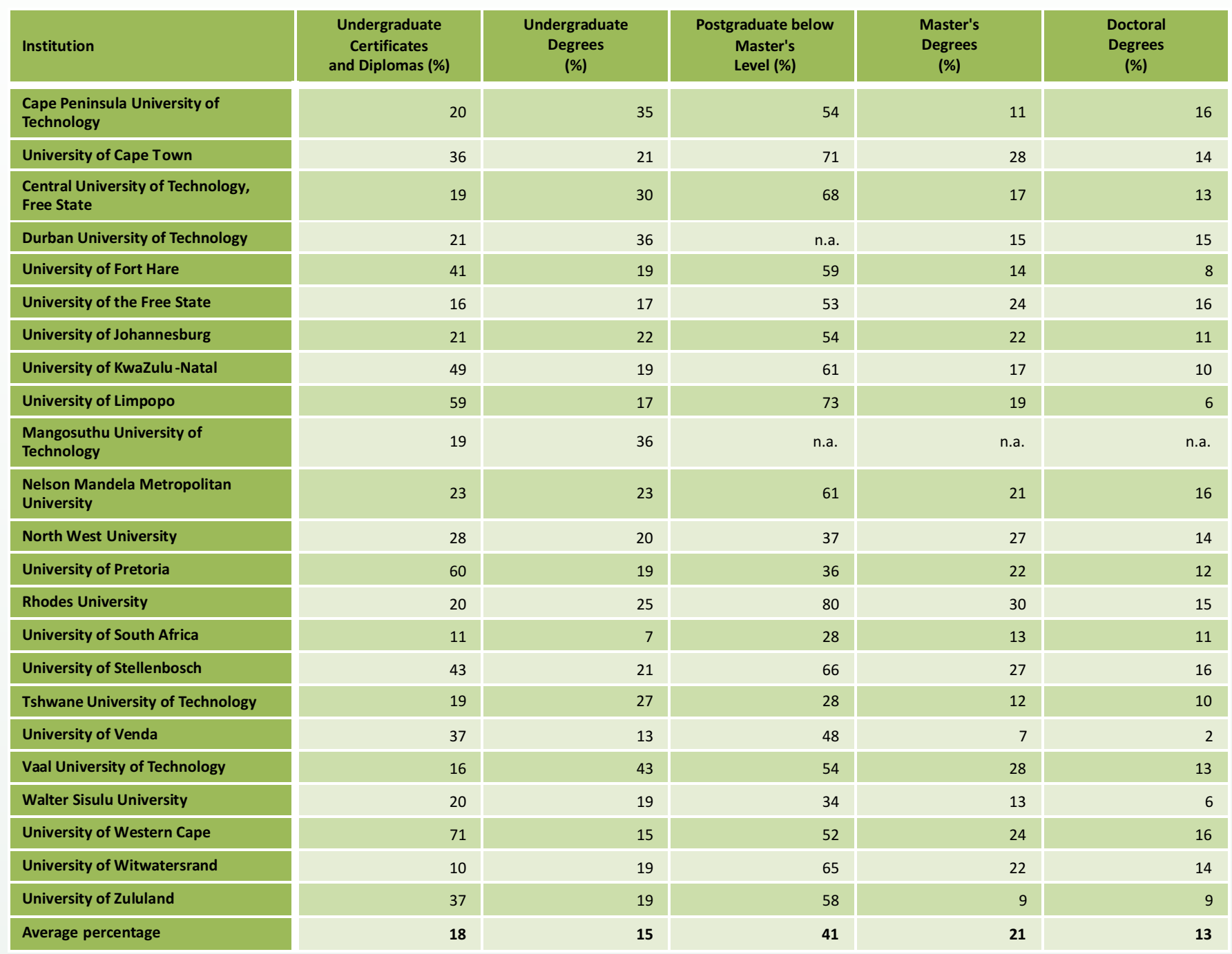

Source: 2013 HEMIS database, extracted in October 2014.

Note 1: These graduation rates serve as proxies for throughput rates of cohorts of students. A detailed account of benchmarks related to these graduation rates can be seen in the National Plan for Higher Education, Department of Education (DOE), 2001.

Note 2: The benchmarks in the National Plan for Higher Education were set on the basis that at least $75 \%$ of any cohort of students entering a programme should complete their Degrees or Diplomas. When converted to graduation rates, the cohort throughput rates in the table above are equivalent to graduation rates of, broadly, the following kind:

\begin{tabular}{|l|c|c|}
\hline & Undergraduate & Doctoral \\
\hline Contact programmes & $25 \%$ & $20 \%$ \\
\hline Distance programmes & $15 \%$ & $15 \%$ \\
\hline
\end{tabular}

Note 3: Graduation rates are calculated based on the number of students who graduate in a particular year, irrespective of the year of study, divided by the total number of students enrolled at Universities in that particular year. The total number of graduates in 2013 (180 823 students) divided by the total number of enrolments in 2013 (983 698 students), translates to an $18.4 \%$ graduation rate. The calculation is in accordance with the National Plan for Higher Education, Section 2.3 : Benchmarks for graduation rates.

Note 4: As a result of rounding off, numbers and percentages may not necessarily add up.

Note 5: Graduation rates include graduates and diplomates.

Note 6: "n.a." means not applicable.

Table 9 shows that graduation rates in public HEls are generally lower than that set by the National Plan for Higher Education (DOE, 2001). In 2013, the average graduation rate of Doctoral students stood at $13 \%$, while that for Master's and Undergraduate Degree and Diploma students was 21\%, 15\% and 18\%, respectively. Table 9 also shows that graduation rates differed widely across public HEls. 
Table 10: Undergraduate success rates of students in public HEls, by attendance mode, population group, and institution, in 2013

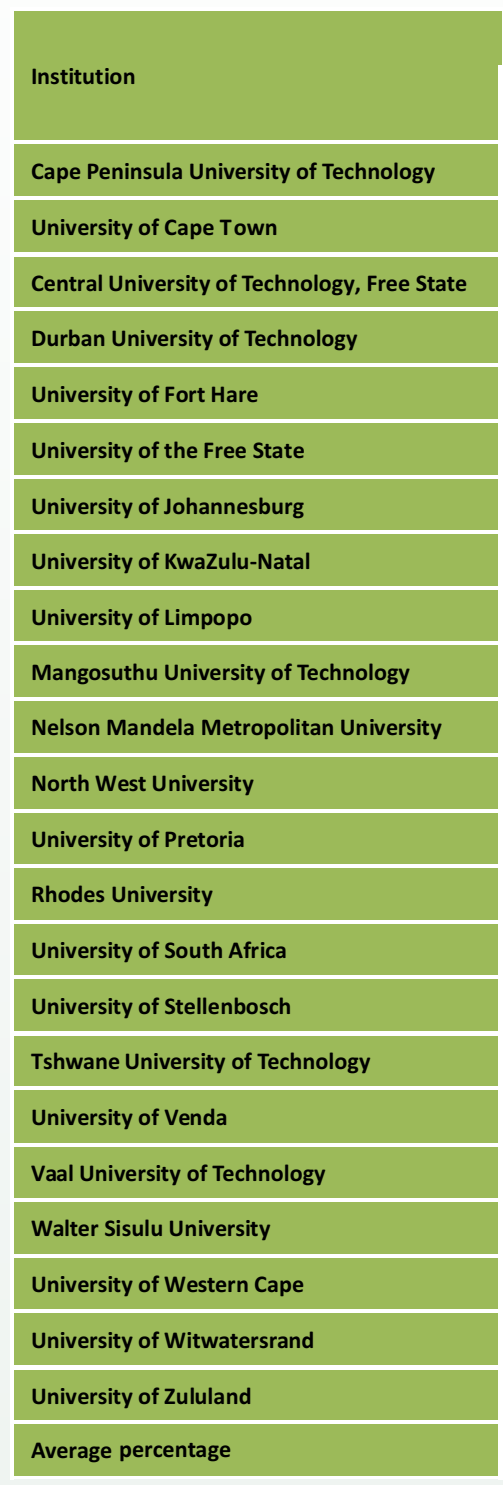

\begin{tabular}{|l|l|c|c|}
\hline \multicolumn{3}{|c}{ Contact (\%) } \\
\hline African & Coloured & $\begin{array}{c}\text { Indian/ } \\
\text { Asian }\end{array}$ & White \\
\hline
\end{tabular}

\begin{tabular}{|l|l|l|l|l|l|}
\hline & \multicolumn{5}{|c|}{ Distance (\%) } \\
\hline Average & African & Coloured & $\begin{array}{c}\text { Indian/ } \\
\text { Asian }\end{array}$ & White & Average \\
\hline
\end{tabular}

\begin{tabular}{|c|c|c|c|c|c|c|c|c|c|}
\hline & & הsicis & & & & & notis & & \\
\hline 73 & 84 & 82 & 88 & 78 & 56 & 82 & 71 & 70 & 63 \\
\hline 81 & 87 & 88 & 93 & 87 & n.a. & n.a. & n.a. & n.a. & n.a. \\
\hline 76 & 77 & 79 & 79 & 76 & 77 & 84 & 100 & 84 & 80 \\
\hline 81 & 84 & 83 & 87 & 81 & n.a. & n.a. & n.a. & n.a. & n.a. \\
\hline
\end{tabular}

\begin{tabular}{|r|r|r|r|r|r|r|r|r|r|}
\hline 81 & 84 & 83 & 87 & n.a. & n.a. & n.a. & n.a. & n.a. \\
\hline 82 & 83 & 82 & 90 & $\mathbf{8 2}$ & n.a. & n.a. & n.a. & n.a. & n.a. \\
\hline 74 & 75 & 80 & 88 & $\mathbf{7 8}$ & 73 & 67 & 62 & 68 & $\mathbf{7 2}$ \\
\hline 83 & 83 & 84 & 88 & 83 & n.a. & n.a. & n.a. \\
\hline
\end{tabular}

\begin{tabular}{|r|r|r|r|r|r|r|r|r|r|r|}
\hline 74 & 80 & $\mathbf{7 8}$ & 73 & 67 & 62 & $\mathbf{7 2}$ \\
\hline 83 & 83 & 84 & 88 & $\mathbf{8 3}$ & n.a. & n.a. & n.a. & n.a. & n.a. \\
\hline 79 & 85 & 85 & 90 & $\mathbf{8 2}$ & 79 & 76 & 92 & 91 & $\mathbf{8 0}$ \\
\hline 85 & 87 & 94 & 97 & $\mathbf{8 6}$ & n.a. & n.a. & n.a. & n.a. & n.a. \\
\hline
\end{tabular}

\begin{tabular}{|r|r|r|r|r|r|r|r|r|r|}
\hline 85 & 87 & 97 & $\mathbf{8 6}$ & n.a. & n.a. & n.a. & n.a. & n.a. \\
\hline 81 & 87 & 69 & 93 & $\mathbf{8 1}$ & n.a. & n.a. & n.a. & n.a. \\
\hline 74 & 78 & 79 & 86 & $\mathbf{7 7}$ & 91 & 95 & n.a. & 100 & $\mathbf{9 2}$ \\
\hline 83 & 83 & 89 & 89 & $\mathbf{8 6}$ & 83 & 87 & 98 & 95 & $\mathbf{8 4}$ \\
\hline
\end{tabular}

76

\begin{tabular}{|c|c|c|c|c|c|c|c|c|c|}
\hline 82 & 83 & 88 & 89 & 85 & n.a. & ก.d. & n. & n.d. & n.a. \\
\hline n.a. & n.a. & n.a. & n.a. & n.a. & 55 & 57 & 61 & 68 & 58 \\
\hline 77 & 81 & 87 & 88 & 86 & n.a. & n.a. & n.a. & n.a. & n.a. \\
\hline 76 & 74 & 82 & 85 & 76 & 76 & 83 & 94 & 87 & 78 \\
\hline 83 & 100 & 99 & 48 & 83 & n.a. & n.a. & n.a. & n.a. & n.a. \\
\hline 74 & 67 & 68 & 69 & 73 & 96 & n.a. & n.a. & n.a. & 96 \\
\hline
\end{tabular}

\begin{tabular}{|r|r|r|r|r|r|}
\hline 82 & 78 & 88 & 97 & 93 & 79 \\
\hline
\end{tabular}

\begin{tabular}{|r|r|r|r|r|r|r|r|r|r|}
\hline 74 & 67 & 69 & $\mathbf{7 3}$ & 96 & n.a. & n.a. & n.a. & n.a. \\
\hline 80 & 82 & 93 & 77 & $\mathbf{8 0}$ & n.a. & n.a. & n.a. & n.a. \\
\hline 76 & 81 & 88 & 92 & $\mathbf{8 0}$ & n.a. & n.a. & n.a. & n.a. & n.a. \\
\hline 78 & 83 & 86 & 91 & $\mathbf{8 2}$ & n.a. & n.a. & n.a. & n.a. & n.a. \\
\hline 82 & 78 & 76 & 85 & $\mathbf{8 2}$ & n.a. & n.a. & n.a. & n.a. & n.a. \\
\hline $\mathbf{7 9}$ & $\mathbf{8 2}$ & $\mathbf{8 5}$ & $\mathbf{8 8}$ & $\mathbf{8 1}$ & $\mathbf{5 8}$ & $\mathbf{6 0}$ & $\mathbf{6 2}$ & $\mathbf{6 8}$ & $\mathbf{6 0}$ \\
\hline
\end{tabular}

Source: 2013 HEMIS database, extracted in September 2014.

Note 1: Undergraduate courses are those coded as lower prediplomate/undergraduate, intermediate prediplomate/undergraduate and higher undergraduate.

Note 2: Success rates are determined as follows: a calculation is made of FTE enrolled student totals for each course category. A further FTE calculation, using the same credit values, is made for each course category for those students who passed the courses. The success rates are then determined as: FTE passes divided by FTE enrolments. The success rates shown are, therefore, weighted averages for contact and distance courses for each population group.

Note 3: As a result of rounding off, numbers and percentages may not necessarily add up.

Note 4: "n.a." means not applicable.

Table 10 shows that in 2013, the average success rate of contact mode students was significantly higher (at $81 \%$ ) than that of distance mode students (at 60\%). As Table 10 and Figure 8 reveal, White students had the highest success rates for both contact and distance modes, whereas African students had the lowest success rates for both modes of study. 
Figure 8: Percentage distribution of average undergraduate success rates in public HEls, by contact education programme and population group, in 2013

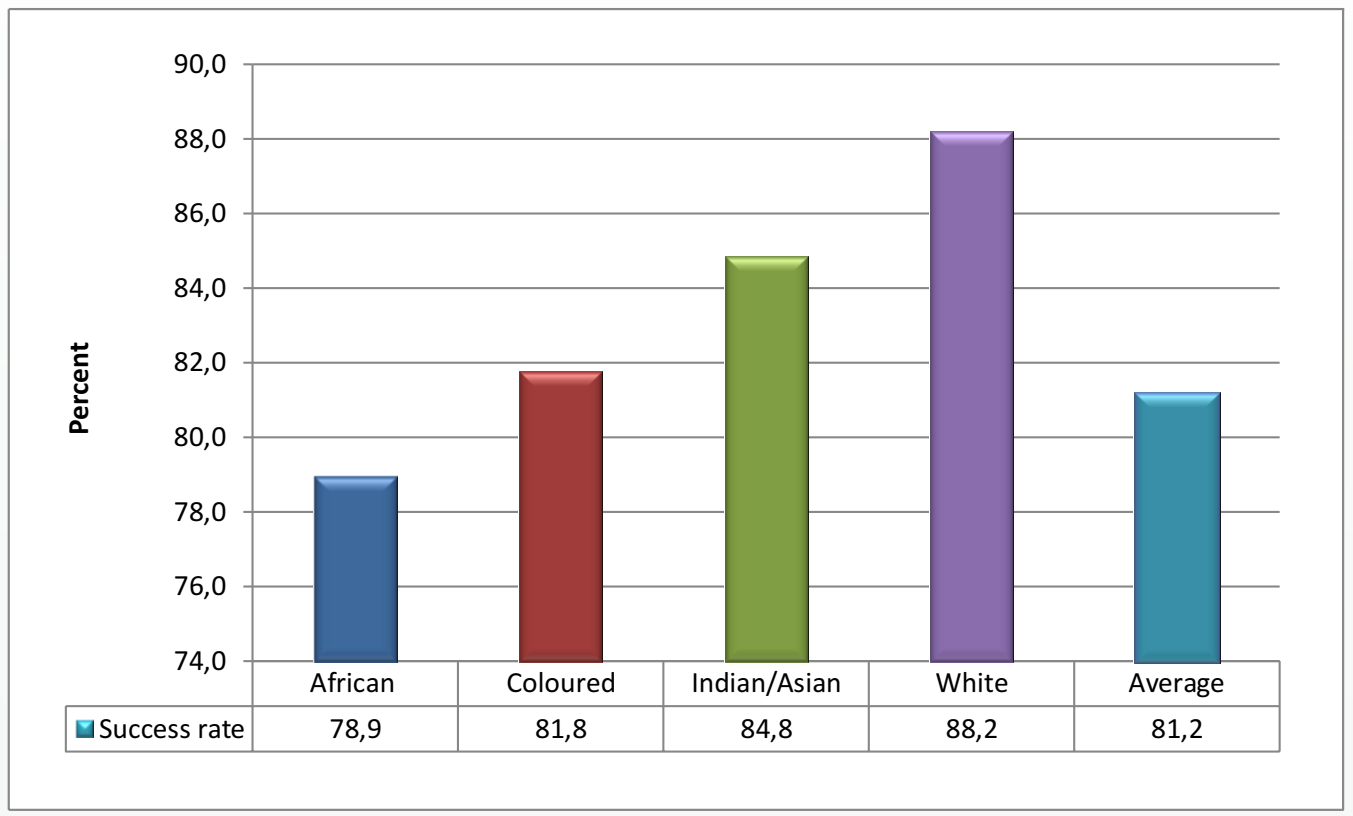

Source: 2013 HEMIS database, extracted in October 2014. 


\subsubsection{Staffing in public HEls}

Table 11: Number and percentage of permanent staff in public HEls, by population group, gender, personnel categories and institution, in 2013

\begin{tabular}{|c|c|c|c|c|c|c|c|c|c|}
\hline \multirow[b]{2}{*}{ Institution } & \multicolumn{3}{|c|}{ Total Permanent Staff } & \multicolumn{3}{|c|}{$\%$ of Black Staff in total } & \multicolumn{3}{|c|}{$\%$ of Female Staff in total } \\
\hline & $\begin{array}{l}\text { Instruction } \\
\text { and } \\
\text { Research } \\
\text { Staff }\end{array}$ & $\begin{array}{l}\text { Administrative } \\
\text { Staff }\end{array}$ & $\begin{array}{l}\text { Service } \\
\text { Staff }\end{array}$ & $\begin{array}{l}\text { Instruction } \\
\text { and } \\
\text { Research } \\
\text { Staff }\end{array}$ & $\begin{array}{l}\text { Administrative } \\
\text { Staff }\end{array}$ & $\begin{array}{l}\text { Service } \\
\text { Staff }\end{array}$ & $\begin{array}{l}\text { Instruction } \\
\text { and } \\
\text { Research } \\
\text { Staff }\end{array}$ & $\begin{array}{l}\text { Administrative } \\
\text { Staff }\end{array}$ & $\begin{array}{l}\text { Service } \\
\text { Staff }\end{array}$ \\
\hline $\begin{array}{l}\text { Cape Peninsula University of } \\
\text { Technology }\end{array}$ & 768 & 973 & 152 & 60 & 84 & 99 & 41 & 59 & 26 \\
\hline $\begin{array}{l}\text { Central University of Technology, } \\
\text { Free State }\end{array}$ & 291 & 342 & 98 & 46 & 64 & 98 & 40 & 58 & 55 \\
\hline Durban University of Technology & 579 & 767 & 74 & 73 & 91 & 100 & 47 & 53 & 20 \\
\hline University of Fort Hare & 327 & 520 & 27 & 72 & 89 & 100 & 38 & 56 & 11 \\
\hline University of the Free State & 962 & 1165 & 318 & 23 & 35 & 97 & 49 & 67 & 51 \\
\hline University of Johannesburg & 1024 & 1894 & 253 & 43 & 68 & 98 & 44 & 53 & 34 \\
\hline University of Limpopo & 884 & 725 & 278 & 85 & 84 & 100 & 43 & 59 & 44 \\
\hline $\begin{array}{l}\text { Mangosuthu University of } \\
\text { Technology }\end{array}$ & 195 & 263 & 80 & 90 & 96 & 100 & 33 & 52 & 45 \\
\hline $\begin{array}{l}\text { Nelson Mandela Metropolitan } \\
\text { University }\end{array}$ & 606 & 993 & 74 & 27 & 58 & 92 & 47 & 62 & 31 \\
\hline North West University & 1288 & 1809 & 380 & 27 & 32 & 95 & 46 & 66 & 47 \\
\hline University of Pretoria & 1300 & 1598 & 362 & 22 & 48 & 90 & 50 & 66 & 33 \\
\hline Rhodes University & 351 & 547 & 451 & 25 & 56 & 99 & 42 & 61 & 51 \\
\hline University of South Africa & 1631 & 3137 & 79 & 50 & 72 & 99 & 50 & 58 & 25 \\
\hline University of Stellenbosch & 1006 & 1909 & 251 & 21 & 48 & 99 & 43 & 63 & 41 \\
\hline $\begin{array}{l}\text { Tshwane University of } \\
\text { Technology }\end{array}$ & 917 & 1468 & 142 & 56 & 74 & 99 & 42 & 53 & 37 \\
\hline University of Venda & 337 & 319 & 147 & 93 & 99 & 100 & 35 & 51 & 59 \\
\hline Walter Sisulu University & 576 & 671 & 156 & 87 & 96 & 100 & 43 & 57 & 52 \\
\hline University of Western Cape & 574 & 928 & 27 & 62 & 94 & 100 & 50 & 58 & 7 \\
\hline University of Witwatersrand & 1093 & 1479 & 310 & 38 & 74 & 100 & 46 & 65 & 30 \\
\hline University of Zululand & 299 & 379 & 175 & 81 & 92 & 100 & 41 & 49 & 39 \\
\hline Total & 17838 & 26667 & 4380 & 47 & 68 & 98 & 45 & 60 & 42 \\
\hline
\end{tabular}

Source: 2013 HEMIS database, extracted in October 2014.

Note 1: A permanent staff member is defined as an employee who contributes to an institutional pension or retirement fund.

Note 2: Instruction/research staff (also referred to as academic staff) are those who spend more than $50 \%$ of their official time on duty on instruction and research activities.

Note 3: The category "administrative staff" includes all executive and professional staff who spend less than $50 \%$ of their official time on duty on instruction and research activities, as well as all technical and office staff.

Note 4: The category "service staff" includes all staff, such as cleaners, gardeners, security guards and messengers, who are not engaged in supervisory or administrative functions linked to an office.

Note 5: Black staff, for the purpose of this summary table, includes all African, Coloured and Indian/Asian staff employed on a permanent contract.

Note 6: As a result of rounding off, numbers and percentages may not necessarily add up.

Table 11 compares the number and percentage of permanent staff in public HEls by institution. It shows that in 2013, more than 17800 staff were employed as instruction and research staff, 26600 as administrative staff and 4300 as service staff at public HEls. Less than half of all instruction and research staff employed at public HEls in 2013 were Black (47\%), while $45 \%$ of all instruction and research staff were female. Most of the service staff employed at public HEIs in 2013 were African (98\%), while females comprised most of the administrative staff at public HEls in 2013 (at $60 \%)$. 


\subsection{PRIVATE HEIs}

\subsubsection{Introduction}

In terms of the Public Notice (Government Gazette No. 19389, dated 30 October 1998), no private institution is permitted to offer HE in South Africa as of 1 January 2000, unless registered with the DHET. In terms of the Higher Education Act, 1997 (Act No. 101 of 1997), and the Regulations for the registration of Private HEls published in Government Gazette No. 24143, dated 13 December 2002, all private institutions providing HE, that is, programmes equivalent to those provided by traditional Universities, Comprehensive Universities and Universities of Technology that fall on the Higher Education Qualifications Sub-Framework (HEQSF), must be registered with the DHET. This requirement applies to both local and foreign institutions.

The total student enrolment figures for private HEls provided below are based on student enrolment per HE programme per institution as listed on the Register of Private HEls. The register is available on the Department's website at www.dhet.gov.za

In 2013, 114 private HEls were registered with the Department. However only 113 private HEls submitted data to the Department.

\subsubsection{Enrolment in private HEls}

Table 12: Number of students enrolled in private HEls, by gender, from 2011 to 2013

\begin{tabular}{|l|c|c|c|c|}
\hline Year & Male & Female & Total \\
\hline $\mathbf{2 0 1 1}$ & & 48876 & 54160 & $\mathbf{1 0 3 0 3 6}$ \\
\hline $\mathbf{2 0 1 2}$ & 43704 & 53774 & $\mathbf{9 7 4 7 8}$ \\
\hline $\mathbf{2 0 1 3}$ & 55606 & 64335 & $\mathbf{1 1 9 9 4 1}$ \\
\hline
\end{tabular}

Source: Annual Reports submitted to DHET by private HEIs, April 2013.

Note: The figures provided in the above table are not audited.

Table 12 shows that the total number of students enrolled in private HEls in 2013 were approximately 120000 . This figure reflects an increase in student enrolment from 2011 to 2013, although the figure decreased from about 103000 in 2011 to approximately 97000 in 2012. As was the case with public HEls, female enrolment in private HEls was consistently higher than that of males over the period 2011 to 2013.

Table 13: Number of students enrolled in private HEls, by population group and nationality, from 2011 to 2013

\begin{tabular}{|c|c|c|c|c|c|c|c|}
\hline Year & African & Coloured & $\begin{array}{c}\text { Indian/ } \\
\text { Asian }\end{array}$ & White & $\begin{array}{l}\text { Total South } \\
\text { African } \\
\text { students }\end{array}$ & $\begin{array}{l}\text { Non-South } \\
\text { African } \\
\text { students }\end{array}$ & Total \\
\hline 2011 & 56988 & 7526 & 5913 & 23311 & 93738 & 9298 & 103036 \\
\hline 2012 & 56813 & 6876 & 5222 & 18500 & 87411 & 10067 & 97478 \\
\hline 2013 & 64933 & 8183 & 6649 & 26664 & 106429 & 13512 & 119941 \\
\hline
\end{tabular}

Source: Annual Reports submitted to DHET by private HEIs, April 2013.

Note: The figures provided in the above table are not audited.

Table 13 shows that close to 65000 African students and almost 27000 White students enrolled in private HEls in 2013. It also shows that the number of non-South African students increased steadily from 2011 to 2013, with about 14000 non-South African students enrolled in private HEls in 2013. 


\section{FURTHER EDUCATION AND TRAINING/TECHNICAL AND VOCATIONAL EDUCATION AND TRAINING (FET/TVET)}

\subsection{OVERVIEW OF PUBLICTVET AND PRIVATE FET COLLEGES}

The legislative landscape of the FET College sector has undergone significant changes. Public FET Colleges have been renamed TVET Colleges, while private FET Colleges have been renamed private Colleges in terms of the Further Education and Training Colleges Amendment Act, 2013 (Act No. 1 of 2013), in Government Gazette No. 36271. The Act came into effect on 6 October 2014 in terms of a proclamation (No. 68 of 2014) by order of the President of the Republic of South Africa (Government Gazette No. 38072). Previous issues of the statistics report on Post-School Education and Training refer to FET Colleges and further issues of the statistics report will refer to TVET Colleges.

In general, public FET/TVET Colleges provide three broad categories of qualifications and programmes:

a. The National Certificate (Vocational) $[\mathrm{NC}(\mathrm{V})]$ at three levels (Levels 2, 3 and 4 of the National Qualifications Framework [NQF]), which is an alternative learning pathway to Grades 10, 11 and 12 of the academic schooling system.

b. The "Report 191/National Technical Education (NATED)" Certificates offered at six different levels (N1 to N6), which culminate in a Diploma if students meet the requirements for work experience. Students enrolled for Business Studies require 18 to 24 months of work experience, while those enrolled for Engineering Studies require a minimum of 2000 hours of work experience to obtain the Diploma. Students may also choose to take a trade test on completion of the N1 to N3 certificates whenever they have acquired the necessary practical skills.

c. Occupational qualifications and part-qualifications are based on job-related programmes that are closely linked to workplace demands and opportunities.

Public FET/TVET Colleges have become important providers of occupational learning programmes funded by Sector Education Training and Authorities (SETAs) in terms of the SETA Grant Regulations.

One of the Department's central strategic objectives for the FET/TVET College sector is the need to increase access to, and improve success in programmes that lead to intermediate and high-level learning. In addition to the abovementioned offerings, FET/TVET Colleges are also phasing in the offering of Higher Certificate programmes in collaboration with Higher Education Institutions (HEIs).

This section of the report provides a statistical overview of access to both public FET/TVET and private FET Colleges. The subsequent sections provide further detail on student enrolment and staffing in public FET/TVET and private FET Colleges. Information about student performance in FET/TVET Colleges is provided in the section titled "Examination results". 
Figure 9: Number of students enrolled in public FET/TVET and private FET Colleges, from 2011 to 2013

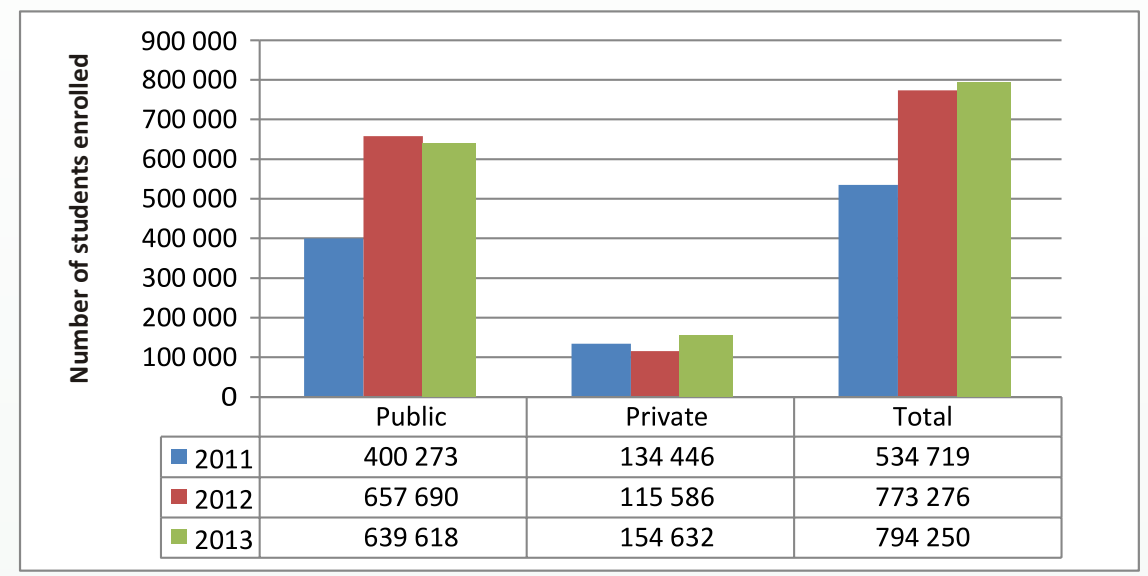

Sources:

2013 Annual Survey of Public FET Colleges 20140807.

2013 Annual Survey of Private FET Colleges 20140726.

Note: Number of students refers to headcount enrolment.

Figure 9 shows that more than 794000 students enrolled in public FET/TVET and private FET Colleges in 2013. Between 2011 and 2013, total student enrolment in FET/TVET Colleges (both public and private) increased from 530 000 in 2011 to about 800000 students in 2013.

Public FET/TVET Colleges experienced an increase in student enrolment between 2011 and 2012 from about 400000 students in 2011 to about 660000 students in 2012 and a decrease in enrolment from 2012 to 2013. During the same period, private FET Colleges experienced a decrease in their enrolment from 135000 students in 2011 to 115000 students in 2012 and an increase in enrolment from 2012 to 2013.

Table 14: Number of students enrolled in public FET/TVET and private FET Colleges, by institutional type, qualification and province, in 2013

\begin{tabular}{|l|}
\hline \\
\hline Province \\
\hline Eastern Cape \\
\hline Free State \\
\hline Gauteng \\
\hline KwaZulu-Natal \\
\hline Limpopo \\
\hline Mpumalanga \\
\hline Northern Cape \\
\hline North West \\
\hline Western Cape \\
\hline Unspecified \\
\hline National \\
\hline
\end{tabular}

\begin{tabular}{|r|r|}
\hline NC(V) & $\begin{array}{c}\text { Report 191 } \\
\text { N1-N6 }\end{array}$ \\
\hline 18838 & 33095 \\
\hline 6344 & 45224 \\
\hline 33663 & 130247 \\
\hline 33576 & 83630 \\
\hline 23143 & 44995 \\
\hline 9031 & 22546 \\
\hline 3045 & 8693 \\
\hline 12197 & 33151 \\
\hline 15123 & 40706 \\
\hline n.a. & n.a. \\
\hline 154960 & 442287 \\
\hline
\end{tabular}

\begin{tabular}{|r|}
\hline Public \\
\hline \begin{tabular}{|r|} 
Occupational \\
Qualifications
\end{tabular} \\
\hline 1196 \\
\hline 156 \\
\hline 1035 \\
\hline 2175 \\
\hline 331 \\
\hline 940 \\
\hline 536 \\
\hline 859 \\
\hline 11772 \\
\hline n.a. \\
\hline 19000 \\
\hline
\end{tabular}

\begin{tabular}{|c|c|c|}
\hline $\begin{array}{l}\text { eport 550/ } \\
\text { NSC }\end{array}$ & Other & Total \\
\hline 807 & 577 & 54513 \\
\hline 593 & 1413 & 53730 \\
\hline 0 & 8082 & 173027 \\
\hline 0 & 3137 & 122518 \\
\hline 0 & 913 & 69382 \\
\hline 12 & 256 & 32785 \\
\hline 73 & 841 & 13188 \\
\hline 0 & 2097 & 48304 \\
\hline 208 & 4362 & 72171 \\
\hline n.a. & n.a. & n.a. \\
\hline 1693 & 21678 & 639618 \\
\hline
\end{tabular}

\begin{tabular}{|c|c|c|c|c|}
\hline \multicolumn{5}{|c|}{ Private } \\
\hline $\mathrm{NC}(\mathrm{V})$ & $\begin{array}{l}\text { Report } 191 \\
\text { N1-N6 }\end{array}$ & $\begin{array}{l}\text { Occupational } \\
\text { Qualifications }\end{array}$ & $\begin{array}{l}\text { Report 550/ } \\
\text { NSC \& Other }\end{array}$ & Total \\
\hline 0 & 269 & 7105 & 3245 & 10619 \\
\hline 0 & 111 & 626 & 787 & 1524 \\
\hline 1152 & 9510 & 23799 & 34902 & 69363 \\
\hline 764 & 5138 & 5629 & 6090 & 17621 \\
\hline 0 & 363 & 2659 & 808 & 3830 \\
\hline 0 & 345 & 2149 & 3450 & 5944 \\
\hline 0 & 0 & 44 & 156 & 200 \\
\hline 0 & 66 & 922 & 986 & 1974 \\
\hline 3096 & 449 & 8466 & 20727 & 32738 \\
\hline n.a. & 3216 & 7001 & 602 & 10819 \\
\hline 5012 & 19467 & 58400 & 71753 & 154632 \\
\hline
\end{tabular}

Sources:

2013 Annual Survey of Public FET Colleges 20140807.

2013 Annual Survey of Private FET Colleges 20140726.

Note 1: $N C(V)$ refers to the National Certificate (Vocational).

Note 2: Report 191 refers to NATED programmes, N1 to N6.

Note 3: "Occupational Qualifications" refer to qualifications associated with a trade, occupation or profession resulting from work-based learning, and consisting of knowledge unit standards, practical unit standards and work experience unit standards.

Note 4: NSC refers to the old National Senior Certificate (which is equivalent to Grade 12).

Note 5: "Other" in FET/TVET Colleges refers to all other skills development and short courses.

Note 6: "n.a." means "not applicable".

Note 7: Unspecified means that the name of the province was not captured on the survey form. 
Table 14 indicates that of the approximately 640000 students enrolled in public FET/TVET Colleges in 2013, the majority (about 442 000) enrolled for $\mathrm{N}$ courses (N1 to N6). About 155000 students in public FET/TVET Colleges enrolled for the NC(V) programme in 2013, while 19000 enrolled for occupational qualifications. Most students in private FET Colleges enrolled for Report 550/NSC and other types of qualifications in 2013. In several provinces, private FET Colleges did not offer the NC(V) programme at all.

Table 14 also shows that Gauteng had the highest number of students enrolled in its Colleges in 2013, followed by the Western Cape and KwaZulu-Natal.

Table 15: Number of students in public FET/TVET and private FET Colleges who wrote and completed examinations, by qualification type, from 2011 to 2013

\begin{tabular}{|c|c|c|c|c|c|c|c|c|c|}
\hline \multirow[b]{2}{*}{ Year } & \multicolumn{3}{|c|}{$\mathrm{NC}(\mathrm{V})$ Level 4} & \multicolumn{3}{|c|}{ Report 191 N3 } & \multicolumn{3}{|c|}{ Report 191 N6 } \\
\hline & $\begin{array}{l}\text { Number } \\
\text { wrote }\end{array}$ & $\begin{array}{l}\text { Number } \\
\text { completed }\end{array}$ & $\begin{array}{c}\text { Completion } \\
\text { rate (\%) }\end{array}$ & $\begin{array}{l}\text { Number } \\
\text { wrote }\end{array}$ & $\begin{array}{l}\text { Number } \\
\text { completed }\end{array}$ & $\begin{array}{l}\text { Completion } \\
\text { rate (\%) }\end{array}$ & $\begin{array}{l}\text { Number } \\
\text { wrote }\end{array}$ & $\begin{array}{l}\text { Number } \\
\text { completed }\end{array}$ & $\begin{array}{l}\text { Completion } \\
\text { rate (\%) }\end{array}$ \\
\hline 2011 & 17836 & 7638 & 42.8 & 2909 & 1366 & 47 & 2428 & 1488 & 61.3 \\
\hline 2012 & 15334 & 6018 & 39.3 & 9928 & 3724 & 37.5 & 8735 & 2902 & 33.2 \\
\hline 2013 & 22470 & 8346 & 37.1 & 65788 & 26186 & 39.8 & 52052 & 18584 & 35.7 \\
\hline
\end{tabular}

\section{Sources:}

Statistics on Post-School Education and Training in South Africa (2012).

National Examinations Database, 2013.

Note 1: The number of students who WROTE and COMPLETED include only those who were eligible to complete qualifications (part or full) during the 2013 academic year.

Note 2: "Number wrote" refers to the number of students who wrote the relevant examinations in 2013 and were eligible to complete the relevant qualifications during the 2013 academic year. This number excludes students who wrote individual subjects but who were not eligible to complete the relevant qualifications in 2013.

Note 3: "Completion rate" refers to the number of students who successfully completed the relevant qualification in the 2013 academic year expressed as a percentage of the number of students who were eligible to complete the qualification and wrote the examinations.

Table 15 shows that the number of students who wrote and completed examinations for NC(V) Level 4 and Report 191 N3 and N6 qualifications increased from 2011 to 2013. However, the actual completion rates decreased over the same period. 


\subsection{PUBLICFET/TVET COLLEGES}

\subsubsection{Introduction}

The expansion and growth of the FET/TVET College sector remain a strategic priority of the Department. Therefore, the performance of the sector is closely monitored. The phase-out of the N1 to N6 certificate programmes was halted in November 2010 to include training of artisans and broaden the learning options available to Matriculants.

The information reflected in this section relates to the scope, size and general demographics of public FET/TVET Colleges as reflected per province. Staffing and student headcount and Full-Time Equivalent (FTE) enrolment statistics are also reflected per college and per programme offering. This information can be used to reflect on the performance of the public FET/TVET College sector against pre-determined strategic objectives.

\subsubsection{Overview of the public FET/TVET sector}

Table 16: Number of public FET/TVET Colleges, lecturers and students, by province, in 2013

\begin{tabular}{|c|c|c|c|}
\hline Province & FET Colleges & Lecturers & Students \\
\hline Eastern Cape & 8 & 1151 & 54513 \\
\hline Free State & 4 & 605 & 53730 \\
\hline Gauteng & 8 & 2086 & 173027 \\
\hline KwaZulu-Natal & 9 & 2299 & 122518 \\
\hline Mpumalanga & 3 & 600 & 32785 \\
\hline Northern Cape & 3 & 180 & 13188 \\
\hline North West & 2 & 610 & 48304 \\
\hline Western Cape & 6 & 1535 & 72171 \\
\hline National & 50 & 10106 & 639618 \\
\hline
\end{tabular}

Source: 2013 Annual Survey of Public FET Colleges 20140807.

Table 16 shows that in 2013, there were 50 public FET/TVET Colleges in South Africa with a total headcount student enrolment of approximately 640000 students and a staff complement of more than 10000 lecturers. The number of public FET/TVET Colleges across provinces range from two (North West) to nine (KwaZulu-Natal), with each having a number of campuses. As indicated in Table 16, student enrolment in public FET/TVET Colleges was the highest in Gauteng and the lowest in the Northern Cape. 


\subsubsection{Enrolment in public FET/TVET Colleges}

Figure 10: Number of students enrolled in public FET/TVET Colleges, by qualification category, from 2010 to 2013

\begin{tabular}{|c|c|c|c|c|c|c|}
\hline \multirow{14}{*}{ 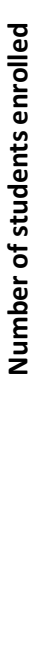 } & \multirow{2}{*}{\multicolumn{6}{|c|}{$\begin{array}{l}500000 \\
450000\end{array}$}} \\
\hline & & & & & & \\
\hline & \multirow{2}{*}{\multicolumn{5}{|c|}{350000}} & \\
\hline & & \multicolumn{5}{|c|}{300000} \\
\hline & \multicolumn{6}{|l|}{250000} \\
\hline & \multicolumn{6}{|l|}{200000} \\
\hline & \multicolumn{6}{|l|}{150000} \\
\hline & \multicolumn{6}{|l|}{$\begin{array}{r}100000 \\
50000\end{array}$} \\
\hline & & & & $=1$ & $\square$ & $\theta$ \\
\hline & & $\mathrm{NC}(\mathrm{V})$ & Report 191 & $\begin{array}{l}\text { Occupational } \\
\text { Qualifications }\end{array}$ & Other & \\
\hline & 2010 & 130039 & 169774 & 23160 & 31504 & \\
\hline & 2011 & 124658 & 222754 & 20799 & 32062 & \\
\hline & 口2012 & 140575 & 359624 & 62359 & 95132 & \\
\hline & 口 2013 & 154960 & 442287 & 19000 & 23371 & \\
\hline
\end{tabular}

Source: 2013 Annual Survey of Public FET Colleges 20140807.

Note 1: $\mathrm{NC}(\mathrm{V})$ ) refers to the National Certificate (Vocational).

Note 2: Report 191 refers to NATED programmes, N1 to N6.

Note 3: "Occupational Qualifications" refer to qualifications associated with a trade, occupation or profession resulting from work-based learning, and consisting of knowledge unit standards, practical unit standards and work experience unit standards.

Note 4: "Other" in FET/TVET Colleges refers to all other skills development and short courses.

Figure 10 shows that student enrolment for $N C(V)$ and Report 191 study programmes increased since 2011, while enrolment for occupational qualifications and "other" programmes was lower than in previous years. 
Table 17: Number of students enrolled in public FET/TVET Colleges, by college and qualification category, in 2013

\begin{tabular}{|c|c|c|c|c|c|c|c|}
\hline \multirow{2}{*}{ College } & \multirow{2}{*}{$\mathrm{NC}(\mathrm{V})$} & \multirow{2}{*}{$\begin{array}{l}\text { Report } 191 \\
\text { (N1-N3) }\end{array}$} & \multirow{2}{*}{$\begin{array}{l}\text { Report } 191 \\
\text { (N4-N6) }\end{array}$} & \multirow{2}{*}{$\begin{array}{l}\text { Occupational } \\
\text { Qualifications }\end{array}$} & \multirow{2}{*}{ NSC } & \multirow{2}{*}{ Other } & \multirow{2}{*}{ Total } \\
\hline & & & & & & & \\
\hline Boland FET College & 1826 & 587 & 4402 & 1771 & 0 & 1919 & 10505 \\
\hline Buffalo City FET College & 2610 & 917 & 4951 & 0 & 0 & 0 & 8478 \\
\hline Capricorn FET College & 5843 & 462 & 9521 & 0 & 0 & 77 & 15903 \\
\hline Central JHB FET College & 2391 & 10308 & 11592 & 20 & 0 & 615 & 24926 \\
\hline Coastal FET College & 6489 & 3289 & 7233 & 0 & 0 & 105 & 17116 \\
\hline College of Cape Town FET College & 3794 & 1169 & 4846 & 3149 & 208 & 744 & 13910 \\
\hline Eastcape Midlands FET College & 2705 & 2265 & 3855 & 1081 & 0 & 0 & 9906 \\
\hline Ehlanzeni FET College & 1967 & 1869 & 2342 & 0 & 0 & 0 & 6178 \\
\hline Ekurhuleni East FET College & 3960 & 2116 & 7393 & 123 & 0 & 0 & 13592 \\
\hline Ekurhuleni West College & 7102 & 4168 & 8271 & 548 & 0 & 0 & 20089 \\
\hline Elangeni FET College & 4873 & 1795 & 3650 & 132 & 0 & 607 & 11057 \\
\hline Esayidi FET College & 3212 & 2278 & 7861 & 44 & 0 & 80 & 13475 \\
\hline False Bay FET College & 2377 & 1665 & 2149 & 851 & 0 & 735 & 7777 \\
\hline Flavius Mareka FET College & 1071 & 3182 & 6306 & 81 & 0 & 79 & 10719 \\
\hline Gert Sibande FET College & 4520 & 2360 & 2558 & 940 & 12 & 103 & 10493 \\
\hline Goldfields FET College & 1248 & 3092 & 4279 & 0 & 0 & 587 & 9206 \\
\hline Ikhala FET College & 2160 & 797 & 2294 & 92 & 0 & 0 & 5343 \\
\hline Ingwe FET College & 1022 & 219 & 1505 & 0 & 0 & 0 & 2746 \\
\hline King Hintsa FET College & 1198 & 1309 & 880 & 0 & 0 & 0 & 3387 \\
\hline King Sabata Dalindyebo FET College & 3018 & 1930 & 4879 & 0 & 0 & 0 & 9827 \\
\hline Lephalale FET College & 582 & 4512 & 3261 & 0 & 0 & 25 & 8380 \\
\hline Letaba FET College & 2615 & 1162 & 1877 & 0 & 0 & 189 & 5843 \\
\hline Lovedale FET College & 1949 & 445 & 2378 & 23 & 0 & 0 & 4795 \\
\hline Majuba FET College & 5778 & 8637 & 8879 & 0 & 0 & 0 & 23294 \\
\hline Maluti FET College & 1030 & 0 & 3072 & 0 & 0 & 113 & 4215 \\
\hline Mnbithi FET College & 2605 & 0 & 5773 & 0 & 0 & 376 & 8754 \\
\hline Mopani South East FET College & 4133 & 2076 & 2812 & 0 & 0 & 0 & 9021 \\
\hline Motheo FET College & 2995 & 8484 & 16809 & 75 & 593 & 634 & 29590 \\
\hline Mthashana FET College & 2178 & 1770 & 3499 & 0 & 0 & 0 & 7447 \\
\hline Nkangala FET College & 2544 & 8007 & 5410 & 0 & 0 & 153 & 16114 \\
\hline Northern Cape Rural FET College & 1606 & 1332 & 2424 & 401 & 0 & 623 & 6386 \\
\hline Northern Cape Urban FET College & 1439 & 1430 & 3507 & 135 & 73 & 218 & 6802 \\
\hline Northlink FET College & 3143 & 10184 & 12332 & 4485 & 0 & 481 & 30625 \\
\hline Orbit FET College & 6293 & 9382 & 7164 & 333 & & 1003 & 24175 \\
\hline Port Elizabeth FET College & 4176 & 2218 & 2253 & 0 & 807 & 577 & 10031 \\
\hline Sedibeng FET College & 3880 & 4066 & 6555 & 313 & 0 & 52 & 14866 \\
\hline Sekhukhune FET College & 1897 & 2498 & 3440 & 0 & 0 & 0 & 7835 \\
\hline South Cape FET College & 2398 & 472 & 1068 & 1089 & 0 & 119 & 5146 \\
\hline South West Gauteng FET College & 6632 & 5171 & 8528 & 0 & 0 & 857 & 21188 \\
\hline Taletso FET College & 3403 & 1982 & 5276 & 0 & 0 & 0 & 10661 \\
\hline Thekwini FET College & 1780 & 3814 & 6107 & 157 & 0 & 522 & 12380 \\
\hline Tshwane North FET College & 4303 & 7592 & 13378 & 0 & 0 & 699 & 25972 \\
\hline Tshwane South FET College & 3394 & 11305 & 12206 & 0 & 0 & 5123 & 32028 \\
\hline Umfolozi FET College & 5216 & 3070 & 6550 & 1842 & 0 & 641 & 17319 \\
\hline Umgungundlovu FET College & 1445 & 2586 & 6839 & 0 & 0 & 806 & 11676 \\
\hline Vhembe FET College & 4906 & 2159 & 10841 & 0 & 0 & 622 & 18528 \\
\hline Vuselela FET College & 2501 & 5345 & 4002 & 526 & 0 & 1094 & 13468 \\
\hline Waterberg FET College & 3167 & 35 & 339 & 331 & 0 & 0 & 3872 \\
\hline West Coast FET College & 1585 & 944 & 888 & 427 & 0 & 364 & 4208 \\
\hline Western FET College & 2001 & 8360 & 9238 & 31 & 0 & 736 & 20366 \\
\hline Total & 154960 & 164815 & 277472 & 19000 & 1693 & 21678 & 639618 \\
\hline
\end{tabular}

Source: 2013 Annual Survey of Public FET Colleges 20140807.

Note 1: $\quad \mathrm{NC}(\mathrm{V})$ refers to the National Certificate (Vocational) Levels 2 to 4.

Note 2: Report 191 refers to NATED programmes, N1 to N6. It is a part-qualification.

Note 3: "Occupational Qualifications" refer to qualifications associated with a trade, occupation or profession resulting from work-based learning, and consisting of knowledge unit standards, practical unit standards and work experience unit standards.

Note 4: NSC refers to the old National Senior Certificate (which is equivalent to Grade 12).

Note 5: "Other" in FET/TVET Colleges refers to all other skills development and short courses. 
Table 17 indicates that in 2013, the majority of students in public FET/TVET Colleges, more than 277000 enrolled for Report 191 (N4 to N6) certificate programmes, while more than 164000 and 154000 students, respectively, enrolled for Report 191 (N1 to N3) certificate programmes and NC(V) qualifications. With 32028 students, Tshwane South FET College had the highest student enrolment in 2013, followed by Northlink and Motheo FET Colleges. Ingwe FET College had the lowest student enrolment at 2746.

Table 18: Number of students enrolled in public FET/TVET Colleges, by qualification category and population group, in 2013

\begin{tabular}{|c|c|c|c|c|c|c|c|}
\hline Qualification Category & African & Coloured & Indian & White & Other & $\begin{array}{l}\text { Unspecified/ } \\
\text { Double Counts }\end{array}$ & Total \\
\hline Report 191 & 395908 & 24935 & 3319 & 11252 & 292 & 6581 & 435706 \\
\hline Report 550/NSC & 1558 & 114 & 3 & 18 & 0 & 0 & 1693 \\
\hline$N C(V)$ & 145220 & 9258 & 529 & 966 & 125 & -1138 & 156098 \\
\hline Occupational Qualifications & 10562 & 7250 & 134 & 1134 & 44 & -124 & 19124 \\
\hline Total & 553248 & 41557 & 3985 & 13370 & 461 & n.a. & 612621 \\
\hline
\end{tabular}

Source: 2013 Annual Survey of Public FET Colleges 20140807.

Note 1: Report 191 refers to the NATED programmes, N1 to N6. It is a part-qualification.

Note 2: NSC refers to the old National Senior Certificate (which is equivalent to Grade 12).

Note 3: $\mathrm{NC}(\mathrm{V})$ refers to the National Certificate (Vocational) Levels 2 to 4.

Note 4: "Occupational Qualifications" refer to qualifications associated with a trade, occupation or profession resulting from work-based learning, and consisting of knowledge unit standards, practical unit standards and work experience unit standards.

Note 5: "Other" in FET/TVET Colleges refers to all other skills development and short courses.

Note 6: "n.a." means not applicable.

Note 7: The DHET uses the racial descriptors: "African", "Coloured", "White" and "Indian/Asian" for planning, monitoring and funding purposes. The Department places on record that these racial descriptors, which characterised apartheid policies and practices in the past, are being used to provide historical context and comparisons and to describe and measure the effects of present policy as well as practice on redressing the inequities of the past as required by the Constitution of South Africa.

Table 18 indicates that in 2013, the majority of students in public FET/TVET College Colleges (more than 553000 ) were African, while relatively smaller numbers were Coloured (about 42000 ), White (over 13000 ) and Indian (about 4000 ).

Table 19: Number of students enrolled in public FET/TVET Colleges, by qualification category and gender, in 2013

\begin{tabular}{|c|c|c|c|}
\hline Qualification Category & Female & Male & Total \\
\hline Report 191 & 218691 & 223596 & 442287 \\
\hline Report 550/NSC & 1054 & 639 & 1693 \\
\hline $\mathrm{NC}(\mathrm{V})$ & 87078 & 67882 & 154960 \\
\hline Occupational Qualifications & 11078 & 7922 & 19000 \\
\hline Other & 9190 & 12488 & 21678 \\
\hline Total & 327091 & 312527 & 639618 \\
\hline
\end{tabular}

Source: 2013 Annual Survey of Public FET Colleges 20140807.

Note 1: Report 191 refers to the NATED programmes, N1 to N6. It is a part-qualification.

Note 2: NSC refers to the old National Senior Certificate (which is equivalent to Grade 12).

Note 3: NC(V) refers to the National Certificate (Vocational), Levels 2 to 4.

Note 4: "Occupational Qualifications" refer to qualifications associated with a trade, occupation or profession resulting from work-based learning, and consisting of knowledge unit standards, practical unit standards and work experience unit standards.

Note 5: "Other" in FET/TVET Colleges refers to all other skills development and short courses.

Table 19 indicates that in 2013, female student enrolment in public FET/TVET Colleges exceeded that of male student enrolment by a relatively small margin. More females than males enrolled for the $\mathrm{NC}(\mathrm{V})$ programme in 2013, while more males enrolled for Report 191 programmes. 
Table 20: Number of students enrolled in public FET/TVET Colleges for Report 191 programmes, by level and gender, in 2013

\begin{tabular}{|c|c|c|c|c|c|}
\hline Report 191 & Female & Male & Total & Female (\%) & Male (\%) \\
\hline N1 & 17879 & 34038 & 51917 & 34.4 & 65.6 \\
\hline N2 & 22585 & 43568 & 66153 & 34.1 & 65.9 \\
\hline N3 & 15825 & 30920 & 46745 & 33.9 & 66.2 \\
\hline N4 & 79365 & 55466 & 134831 & 58.9 & 41.1 \\
\hline N5 & 49064 & 35231 & 84295 & 58.2 & 41.8 \\
\hline N6 & 33973 & 24373 & 58346 & 58.2 & 41.8 \\
\hline Total & 218691 & 223596 & 442287 & 49.5 & 50.6 \\
\hline
\end{tabular}

Source: 2013 Annual Survey of Public FET Colleges 20140807.

Note: Report 191 refers to NATED programmes, N1 to N6. It is a part-qualification.

Table 20 indicates that in 2013, males comprised a higher proportion of students (approximately 66\%) enrolled for N1 to N3 programmes in 2013, while females comprised a higher proportion of students enrolled for N4 to N6 programmes.

Table 21: Number of students enrolled in public FET/TVET Colleges for the NC(V), by qualification level and gender, in 2013

\begin{tabular}{|l|l|l|l|l|l|}
\hline Qualification & Female & Male & Total & Female (\%) & Male (\%) \\
\hline NC(V) Level 2 & 49491 & 39745 & $\mathbf{8 9 2 3 6}$ & 55.5 & 44.5 \\
\hline NC(V) Level 3 & 23701 & 17832 & $\mathbf{4 1 5 3 3}$ & 57.1 & 42.9 \\
\hline NC(V) Level 4 & 13886 & 10305 & $\mathbf{2 4 1 9 1}$ & 57.4 & 42.6 \\
\hline Total & $\mathbf{8 7 0 7 8}$ & $\mathbf{6 7 8 8 2}$ & $\mathbf{1 5 4 9 6 0}$ & $\mathbf{5 6 . 2}$ & $\mathbf{4 3 . 8}$ \\
\hline
\end{tabular}

Source: 2013 Annual Survey of Public FET Colleges 20140807.

Table 21 indicates that in 2013, more than $56 \%$ of all students enrolled for $\mathrm{NC}(\mathrm{V})$ programmes were female, while about $44 \%$ were male.

Table 22: Number of students enrolled in public FET/TVET Colleges, by qualification category and age group, in 2013

\begin{tabular}{|c|c|c|c|c|c|c|c|c|}
\hline Qualification Category & $<15$ & $15-19$ & $20-24$ & $25-29$ & $30-34$ & $35-39$ & $40 \geqslant$ & Total \\
\hline Report 191 & 0 & 95638 & 209713 & 61779 & 23402 & 11582 & 7493 & 409607 \\
\hline Report 550/NSC & 0 & 2004 & 809 & 174 & 53 & 31 & 25 & 3096 \\
\hline $\mathrm{NC}(\mathrm{V})$ & 0 & 40215 & 77894 & 17328 & 3819 & 1259 & 339 & 140854 \\
\hline Occupational Qualifications & 0 & 2733 & 5200 & 3244 & 1952 & 1449 & 1583 & 16161 \\
\hline Total & 0 & 140590 & 293616 & 82525 & 29226 & 14321 & 9440 & 569718 \\
\hline
\end{tabular}

Source: 2013 Annual Survey of Public FET Colleges 20140807.

Note 1: Report 191 refers to NATED programmes, N1 to N6. It is a part-qualification.

Note 2: NSC refers to the old National Senior Certificate (which is equivalent to Grade 12).

Note 3: $N C(V)$ refers to the National Certificate (Vocational), Levels 2 to 4.

Note 4: "Occupational Qualifications" refer to qualifications associated with a trade, occupation or profession resulting from work-based learning, and consisting of knowledge unit standards, practical unit standards and work experience unit standards.

Table 22 shows that the majority of students (almost 294000 ) enrolled in public FET/TVET Colleges were in the 20-to24 age group, followed by those in the 15 -to-19 age group. Enrolment generally declines after students reach 25 years of age. 
Table 23: FTE student enrolment in individual public FET/TVET Colleges, by qualification category, in 2013

\begin{tabular}{|c|}
\hline College \\
\hline Boland FET College \\
\hline Buffalo City FET College \\
\hline Capricorn FET College \\
\hline Central JHB FET College \\
\hline Coastal FET College \\
\hline College of Cape Town FET College \\
\hline Eastcape Midlands FET College \\
\hline Ehlanzeni FET College \\
\hline Ekurhuleni East FET College \\
\hline Ekurhuleni West College \\
\hline Elangeni FET College \\
\hline Esayidi FET College \\
\hline False Bay FET College \\
\hline Flavius Mareka FET College \\
\hline Gert Sibande FET College \\
\hline Goldfields FET College \\
\hline Ikhala FET College \\
\hline Ingwe FET College \\
\hline King Hintsa FET College \\
\hline King Sabata Dalindyebo FET College \\
\hline Lephalale FET College \\
\hline Letaba FET College \\
\hline Lovedale FET College \\
\hline Majuba FET College \\
\hline Maluti FET College \\
\hline Mnbithi FET College \\
\hline Mopani South East FET College \\
\hline Motheo FET College \\
\hline Mthashana FET College \\
\hline Nkangala FET College \\
\hline Northern Cape Rural FET College \\
\hline Northern Cape Urban FET College \\
\hline Northlink FET College \\
\hline Orbit FET College \\
\hline Port Elizabeth FET College \\
\hline Sedibeng FET College \\
\hline Sekhukhune FET College \\
\hline South Cape FET College \\
\hline South West Gauteng FET College \\
\hline Taletso FET College \\
\hline Thekwini FET College \\
\hline Tshwane North FET College \\
\hline Tshwane South FET College \\
\hline Umfolozi FET College \\
\hline Umgungundlovu FET College \\
\hline Vhembe FET College \\
\hline Vuselela FET College \\
\hline Waterberg FET College \\
\hline West Coast FET College \\
\hline Western FET College \\
\hline Total \\
\hline
\end{tabular}

\begin{tabular}{|c|c|}
\hline $\mathrm{NC}(\mathrm{V})$ & Report 191 (N1-N3) \\
\hline 2566 & 293 \\
\hline 2518 & 602 \\
\hline 1887 & 245 \\
\hline 2734 & 458 \\
\hline 1521 & 367 \\
\hline 2555 & 580 \\
\hline 1588 & 136 \\
\hline 3404 & 529 \\
\hline 803 & 722 \\
\hline 1157 & 772 \\
\hline 2466 & 659 \\
\hline 2623 & 2110 \\
\hline 2162 & 2678 \\
\hline 3615 & 552 \\
\hline 5939 & 1080 \\
\hline 3452 & 1127 \\
\hline 5741 & 1542 \\
\hline 3694 & 2135 \\
\hline 3090 & 2974 \\
\hline 1683 & 1904 \\
\hline 6464 & 909 \\
\hline 4709 & 587 \\
\hline 3100 & 748 \\
\hline 5474 & 2751 \\
\hline 2335 & 0 \\
\hline 1941 & 589 \\
\hline 1763 & 1013 \\
\hline 4364 & 690 \\
\hline 1333 & 737 \\
\hline 5429 & 129 \\
\hline 529 & 1039 \\
\hline 2451 & 363 \\
\hline 3256 & 633 \\
\hline 1812 & 590 \\
\hline 5451 & 720 \\
\hline 2986 & 8 \\
\hline 2774 & 738 \\
\hline 4473 & 564 \\
\hline 2560 & 2317 \\
\hline 1506 & 312 \\
\hline 1362 & 409 \\
\hline 4595 & 2146 \\
\hline 2500 & 1004 \\
\hline 2447 & 1501 \\
\hline 1965 & 191 \\
\hline 3773 & 346 \\
\hline 2290 & 541 \\
\hline 2941 & 2513 \\
\hline 2341 & 148 \\
\hline 3274 & 288 \\
\hline 147396 & 45987 \\
\hline
\end{tabular}

\begin{tabular}{|c|c|}
\hline Report 191 (N4-N6) & Total \\
\hline 1184 & 4043 \\
\hline 1537 & 4657 \\
\hline 887 & 3020 \\
\hline 1561 & 4753 \\
\hline 947 & 2836 \\
\hline 1871 & 5006 \\
\hline 868 & 2591 \\
\hline 776 & 4709 \\
\hline 1815 & 3340 \\
\hline 1616 & 3545 \\
\hline 3144 & 6269 \\
\hline 6109 & 10842 \\
\hline 3608 & 8448 \\
\hline 2716 & 6883 \\
\hline 2593 & 9612 \\
\hline 3474 & 8053 \\
\hline 3436 & 10719 \\
\hline 4619 & 10448 \\
\hline 3473 & 9536 \\
\hline 3757 & 7344 \\
\hline 3058 & 10432 \\
\hline 1678 & 6974 \\
\hline 3798 & 7645 \\
\hline 4205 & 12430 \\
\hline 2541 & 4876 \\
\hline 1471 & 4000 \\
\hline 2599 & 5374 \\
\hline 2418 & 7472 \\
\hline 2785 & 4855 \\
\hline 3474 & 9031 \\
\hline 835 & 2402 \\
\hline 988 & 3802 \\
\hline 1214 & 5103 \\
\hline 1377 & 3778 \\
\hline 6112 & 12284 \\
\hline 257 & 3251 \\
\hline 1192 & 4704 \\
\hline 867 & 5904 \\
\hline 1831 & 6709 \\
\hline 1022 & 2840 \\
\hline 1488 & 3259 \\
\hline 2259 & 9000 \\
\hline 2729 & 6234 \\
\hline 1449 & 5396 \\
\hline 2414 & 4570 \\
\hline 1858 & 5978 \\
\hline 1242 & 4073 \\
\hline 4168 & 9623 \\
\hline 470 & 2959 \\
\hline 749 & 4311 \\
\hline 112539 & 305922 \\
\hline
\end{tabular}

Source: Weekly Enrolment Monitoring as at 31 October 2013.

Note 1: As a result of rounding off, numbers may not necessarily add up.

Note 2: $N C(V)$ refers to the National Certificate (Vocational), Levels 2 to 4.

Note 3: Report 191 refers to NATED programmes, N1 to N6. It is a part-qualification.

Note 4: FTE enrolments represent weighted students enrolment. One FTE presents a student who is enrolled for all the subjects of a programme at a particular level. Statistics on FTEs are important, as they are used to allocate resources to public FET/TVET Colleges.

Table 23 shows that there were almost 306000 FTEs in public FET/TVET Colleges in 2013, with the majority of FTEs (147400) enrolled for the NC(V) qualification. 
Majuba FET College had the highest FTE student enrolment at over 12 430, followed by Port Elizabeth FET College. Northern Cape Rural FET College had the lowest number of FTEs at 2402.

\subsubsection{Staffing in public FET/TVET Colleges}

Table 24: Number of staff and students in individual public FET/TVET Colleges, in 2013

\begin{tabular}{|c|}
\hline College \\
\hline Boland FET College \\
\hline Buffalo City FET College \\
\hline Capricorn FET College \\
\hline Central JHB FET College \\
\hline Coastal FET College \\
\hline College of Cape Town FET College \\
\hline Eastcape Midlands FET College \\
\hline Ehlanzeni FET College \\
\hline Ekurhuleni East FET College \\
\hline Ekurhuleni West College \\
\hline Elangeni FET College \\
\hline Esayidi FET College \\
\hline False Bay FET College \\
\hline Flavius Mareka FET College \\
\hline Gert Sibande FET College \\
\hline Goldfields FET College \\
\hline Ikhala FET College \\
\hline Ingwe FET College \\
\hline King Hintsa FET College \\
\hline King Sabata Dalindyebo FET College \\
\hline Lephalale FET College \\
\hline Letaba FET College \\
\hline Lovedale FET College \\
\hline Majuba FET College \\
\hline Maluti FET College \\
\hline Mnbithi FET College \\
\hline Mopani South East FET College \\
\hline Motheo FET College \\
\hline Mthashana FET College \\
\hline Nkangala FET College \\
\hline Northern Cape Rural FET College \\
\hline Northern Cape Urban FET College \\
\hline Northlink FET College \\
\hline Orbit FET College \\
\hline Port Elizabeth FET College \\
\hline Sedibeng FET College \\
\hline Sekhukhune FET College \\
\hline South Cape FET College \\
\hline South West Gauteng FET College \\
\hline Taletso FET College \\
\hline Thekwini FET College \\
\hline Tshwane North FET College \\
\hline Tshwane South FET College \\
\hline Umfolozi FET College \\
\hline Umgungundlovu FET College \\
\hline Vhembe FET College \\
\hline Vuselela FET College \\
\hline Waterberg FET College \\
\hline West Coast FET College \\
\hline Western FET College \\
\hline Total \\
\hline
\end{tabular}

\begin{tabular}{|c|c|}
\hline Staff & Students \\
\hline 732 & 10505 \\
\hline 313 & 8478 \\
\hline 440 & 15903 \\
\hline 247 & 24926 \\
\hline 680 & 17116 \\
\hline 353 & 13910 \\
\hline 426 & 9906 \\
\hline 205 & 6178 \\
\hline 464 & 13592 \\
\hline 560 & 20089 \\
\hline 453 & 11057 \\
\hline 363 & 13475 \\
\hline 418 & 7777 \\
\hline 251 & 10719 \\
\hline 476 & 10493 \\
\hline 207 & 9206 \\
\hline 209 & 5343 \\
\hline 95 & 2746 \\
\hline 250 & 3387 \\
\hline 332 & 9827 \\
\hline 105 & 8380 \\
\hline 238 & 5843 \\
\hline 239 & 4795 \\
\hline 603 & 23294 \\
\hline 138 & 4215 \\
\hline 258 & 8754 \\
\hline 208 & 9021 \\
\hline 474 & 29590 \\
\hline 207 & 7447 \\
\hline 384 & 16114 \\
\hline 178 & 6386 \\
\hline 210 & 6802 \\
\hline 880 & 30625 \\
\hline 425 & 24175 \\
\hline 363 & 10031 \\
\hline 410 & 14866 \\
\hline 270 & 7835 \\
\hline 359 & 5146 \\
\hline 506 & 21188 \\
\hline 301 & 10661 \\
\hline 293 & 12380 \\
\hline 282 & 25972 \\
\hline 564 & 32028 \\
\hline 449 & 17319 \\
\hline 281 & 11676 \\
\hline 333 & 18528 \\
\hline 367 & 13468 \\
\hline 235 & 3872 \\
\hline 157 & 4208 \\
\hline 391 & 20366 \\
\hline 17582 & 639618 \\
\hline
\end{tabular}

Source: 2013 Annual Survey of Public FET Colleges 20140807.

Note: "Staff" refers to persons employed at a public FET/TVET College (this includes management, lecturing and support staff).

Table 24 shows that public FET/TVET Colleges employed more than 17500 staff members in 2013, with Northlink FET College having the highest number of staff (at 880 ), followed by Boland FET College (732). Ingwe FET College had the lowest number of staff at 95 . 
Table 25: Number of staff in individual public FET/TVET Colleges, by staff category and gender, in 2013

\begin{tabular}{|c|c|c|c|c|c|c|c|c|}
\hline \multirow{2}{*}{ College } & \multicolumn{2}{|c|}{ Management Staff } & \multicolumn{2}{|c|}{ Lecturing Staff } & \multicolumn{2}{|c|}{ Support Staff } & \multicolumn{2}{|c|}{ Total } \\
\hline & Female & Male & Female & Male & Female & Male & Female & Male \\
\hline Boland FET College & 9 & 12 & 258 & 140 & 231 & 82 & 498 & 234 \\
\hline Buffalo City FET College & 1 & 2 & 119 & 69 & 81 & 41 & 201 & 112 \\
\hline Capricorn FET College & 0 & 2 & 117 & 161 & 96 & 64 & 213 & 227 \\
\hline Central JHB FET College & 0 & 1 & 63 & 88 & 43 & 52 & 106 & 141 \\
\hline Coastal FET College & 43 & 23 & 187 & 211 & 106 & 110 & 336 & 344 \\
\hline College of Cape Town FET College & 2 & 6 & 122 & 106 & 84 & 33 & 208 & 145 \\
\hline Eastcape Midlands FET College & 1 & 2 & 98 & 146 & 112 & 67 & 211 & 215 \\
\hline Ehlanzeni FET College & 5 & 8 & 42 & 73 & 52 & 25 & 99 & 106 \\
\hline Ekurhuleni East FET College & 1 & 2 & 137 & 123 & 117 & 84 & 255 & 209 \\
\hline Ekurhuleni West College & 4 & 5 & 173 & 152 & 126 & 100 & 303 & 257 \\
\hline Elangeni FET College & 3 & 0 & 125 & 142 & 95 & 88 & 223 & 230 \\
\hline Esayidi FET College & 12 & 9 & 119 & 102 & 73 & 48 & 204 & 159 \\
\hline False Bay FET College & 1 & 3 & 97 & 125 & 122 & 70 & 220 & 198 \\
\hline Flavius Mareka FET College & 14 & 4 & 58 & 69 & 62 & 44 & 134 & 117 \\
\hline Gert Sibande FET College & 1 & 4 & 117 & 107 & 137 & 110 & 255 & 221 \\
\hline Goldfields FET College & 2 & 2 & 60 & 61 & 43 & 39 & 105 & 102 \\
\hline Ikhala FET College & 1 & 2 & 42 & 39 & 73 & 52 & 116 & 93 \\
\hline Ingwe FET College & 2 & 2 & 13 & 14 & 44 & 20 & 59 & 36 \\
\hline King Hintsa FET College & 2 & 5 & 61 & 51 & 76 & 55 & 139 & 111 \\
\hline King Sabata Dalindyebo FET College & 5 & 5 & 76 & 65 & 94 & 87 & 175 & 157 \\
\hline Lephalale FET College & 1 & 0 & 23 & 39 & 22 & 20 & 46 & 59 \\
\hline Letaba FET College & 3 & 0 & 63 & 74 & 63 & 35 & 129 & 109 \\
\hline Lovedale FET College & 18 & 6 & 43 & 77 & 49 & 46 & 110 & 129 \\
\hline Majuba FET College & 5 & 6 & 184 & 278 & 88 & 42 & 277 & 326 \\
\hline Maluti FET College & 6 & 4 & 52 & 35 & 22 & 19 & 80 & 58 \\
\hline Mnbithi FET College & 4 & 4 & 82 & 90 & 44 & 34 & 130 & 128 \\
\hline Mopani South East FET College & 1 & 7 & 48 & 77 & 39 & 36 & 88 & 120 \\
\hline Motheo FET College & 13 & 20 & 129 & 141 & 109 & 62 & 251 & 223 \\
\hline Mthashana FET College & 3 & 2 & 60 & 65 & 39 & 38 & 102 & 105 \\
\hline Nkangala FET College & 3 & 10 & 109 & 152 & 63 & 47 & 175 & 209 \\
\hline Northern Cape Rural FET College & 1 & 4 & 37 & 52 & 43 & 41 & 81 & 97 \\
\hline Northern Cape Urban FET College & 7 & 8 & 32 & 59 & 48 & 56 & 87 & 123 \\
\hline Northlink FET College & 2 & 13 & 197 & 230 & 272 & 166 & 471 & 409 \\
\hline Orbit FET College & 1 & 2 & 118 & 124 & 96 & 84 & 215 & 210 \\
\hline Port Elizabeth FET College & 1 & 1 & 119 & 119 & 78 & 45 & 198 & 165 \\
\hline Sedibeng FET College & 2 & 5 & 140 & 136 & 84 & 43 & 226 & 184 \\
\hline Sekhukhune FET College & 0 & 1 & 53 & 94 & 63 & 59 & 116 & 154 \\
\hline South Cape FET College & 2 & 3 & 130 & 62 & 105 & 57 & 237 & 122 \\
\hline South West Gauteng FET College & 1 & 4 & 140 & 158 & 116 & 87 & 257 & 249 \\
\hline Taletso FET College & 3 & 2 & 75 & 90 & 70 & 61 & 148 & 153 \\
\hline Thekwini FET College & 4 & 5 & 97 & 102 & 44 & 41 & 145 & 148 \\
\hline Tshwane North FET College & 1 & 2 & 108 & 70 & 64 & 37 & 173 & 109 \\
\hline Tshwane South FET College & 2 & 1 & 122 & 268 & 95 & 76 & 219 & 345 \\
\hline Umfolozi FET College & 8 & 14 & 127 & 162 & 86 & 52 & 221 & 228 \\
\hline Umgungundlovu FET College & 9 & 11 & 71 & 95 & 58 & 37 & 138 & 143 \\
\hline Vhembe FET College & 2 & 4 & 70 & 99 & 103 & 55 & 175 & 158 \\
\hline Vuselela FET College & 1 & 1 & 95 & 108 & 91 & 71 & 187 & 180 \\
\hline Waterberg FET College & 2 & 0 & 51 & 71 & 65 & 46 & 118 & 117 \\
\hline West Coast FET College & 7 & 2 & 34 & 34 & 44 & 36 & 85 & 72 \\
\hline Western FET College & 1 & 3 & 101 & 107 & 135 & 44 & 237 & 154 \\
\hline Total & 223 & 244 & 4794 & 5312 & 4165 & 2844 & 9182 & 8400 \\
\hline
\end{tabular}

Source: 2013 Annual Survey of Public FET Colleges 20140807.

Note 1: Management staff refers to the principal and vice-principal of a public College.

Note 2: Lecturing staff refers to any person who teaches, educates or trains other persons or who provides professional educational services at any College, and who is appointed in a post on any lecturer establishment under the FET Act, 2006 (Act No. 16 of 2006).

Note 3: Support staff refers to any person who renders academic support services; student support services; human resource management; financial management; administration; maintenance of buildings and gardens; catering services; and security services. 
In 2013, the majority of staff in public FET/TVET Colleges were employed as lecturers (10 106), while 7009 persons were employed as support staff and 467 as management staff. Support staff comprised mainly females, while males dominated the lecturing and management staff category. In general, the female population was in the majority at public FET/TVET Colleges at 9182 , compared with males at 8400 .

\subsubsection{Examination results in public FET/TVET Colleges}

Table 26: Number of students in public FET/TVET Colleges who registered, wrote examinations and completed national qualifications, by qualification category and gender, in 2013

\begin{tabular}{|c|c|c|c|c|c|c|c|c|c|}
\hline \multirow{2}{*}{$\begin{array}{l}\text { Qualification } \\
\text { Category }\end{array}$} & \multicolumn{3}{|c|}{ Female } & \multicolumn{3}{|c|}{ Male } & \multirow{2}{*}{$\begin{array}{l}\text { Total } \\
\text { registered }\end{array}$} & \multirow{2}{*}{$\begin{array}{l}\text { Total } \\
\text { wrote }\end{array}$} & \multirow{2}{*}{$\begin{array}{c}\text { Total } \\
\text { completed }\end{array}$} \\
\hline & $\begin{array}{l}\text { Number } \\
\text { registered }\end{array}$ & $\begin{array}{l}\text { Number } \\
\text { wrote }\end{array}$ & $\begin{array}{l}\text { Number } \\
\text { completed }\end{array}$ & $\begin{array}{l}\text { Number } \\
\text { registered }\end{array}$ & $\begin{array}{l}\text { Number } \\
\text { wrote }\end{array}$ & $\begin{array}{l}\text { Number } \\
\text { completed }\end{array}$ & & & \\
\hline Report 191 (N3) & 14816 & 14601 & 6516 & 27212 & 26600 & 11867 & 42028 & 41201 & 18383 \\
\hline Report 191 (N6) & 24715 & 23974 & 7784 & 19417 & 18867 & 7484 & 44132 & 42841 & 15268 \\
\hline NC(V) Level 4 & 14044 & 12807 & 5168 & 10376 & 9123 & 2946 & 24420 & 21930 & 8114 \\
\hline Total & 53575 & 51382 & 19468 & 57005 & 54590 & 22297 & 110580 & 105972 & 41765 \\
\hline
\end{tabular}

Source: National Examinations Database, November 2013.

Note 1: The number of students who REGISTERED, WROTE and COMPLETED include only those who were eligible to complete qualifications (part or full) during the 2013 academic year.

Note 2: "Number registered" refers to the number of students who registered for the relevant examinations in 2013 and were eligible to complete the relevant qualifications during the 2013 academic year. This number excludes students who registered to write individual subjects but who were not eligible to complete the relevant qualifications in 2013.

Note 3: "Number wrote" refers to the number of students who wrote the relevant examinations in 2013 and were eligible to complete the relevant qualifications during the 2013 academic year. This number excludes students who wrote individual subjects but who were not eligible to complete the relevant qualifications in 2013.

Note 4: "Number completed" refers to the number of students who were eligible to complete and successfully completed the relevant qualifications in the 2013 academic year. This number excludes students who may have passed individual subjects but were not eligible to complete the relevant qualifications in 2013.

Table 26 shows that in public FET/TVET Colleges in 2013, more than 110000 students registered for examinations for the Report 191 (N3 and N6) part-qualifications and NC(V) Level 4 qualifications. The highest proportion of students registered for the Report 191 (N6) part-qualification followed by the Report 191 (N3) part-qualification. Overall, more male than female students registered across the different qualification categories. Table 26 also indicates that a significantly large number of students who wrote and were eligible to complete a part-qualification or full qualification during the 2013 academic year did not complete the relevant part-qualification or full qualification in relation to the number that wrote. 
Table 27: Number of students in public FET/TVET Colleges who registered, wrote and completed NC(V) qualifications, by province and level, in 2013

\begin{tabular}{|c|c|c|c|c|c|c|c|c|c|c|c|c|}
\hline \multirow[b]{2}{*}{ Province } & \multicolumn{4}{|c|}{ NC(V) Level 2} & \multicolumn{4}{|c|}{ NC(V) Level 3} & \multicolumn{4}{|c|}{ NC(V) Level 4} \\
\hline & 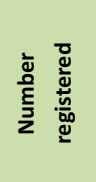 & 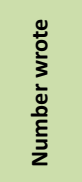 & 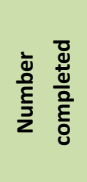 & 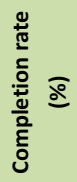 & 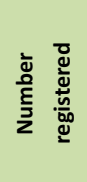 & 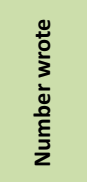 & 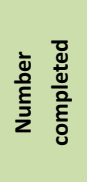 & $\begin{array}{l}\frac{ \pm}{\pi} \\
\frac{0}{0} \\
\frac{0}{0} \\
\frac{0}{0} \\
\frac{0}{0}\end{array}$ & 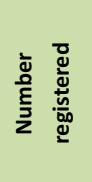 & 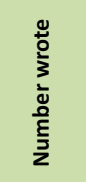 & 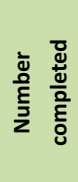 & 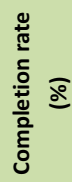 \\
\hline Eastern Cape & 12867 & 9712 & 3459 & 35.6 & 6025 & 5226 & 1807 & 34.6 & 3200 & 2856 & 1143 & 40.0 \\
\hline Free State & 5531 & 3676 & 631 & 17.2 & 1473 & 1188 & 223 & 18.8 & 557 & 461 & 146 & 31.7 \\
\hline Gauteng & 21060 & 14949 & 4284 & 28.7 & 8361 & 7331 & 1975 & 26.9 & 4399 & 4022 & 1318 & 32.8 \\
\hline KwaZulu-Natal & 21815 & 14911 & 4824 & 32.4 & 10262 & 8756 & 2672 & 30.5 & 5094 & 4500 & 1501 & 33.4 \\
\hline Limpopo & 14658 & 11444 & 3310 & 28.9 & 7116 & 6475 & 1519 & 23.5 & 4282 & 3969 & 1246 & 31.4 \\
\hline Mpumalanga & 5889 & 4639 & 2101 & 45.3 & 3365 & 3075 & 1169 & 38.0 & 1901 & 1771 & 791 & 44.7 \\
\hline Northern Cape & 1866 & 1283 & 366 & 28.5 & 777 & 598 & 144 & 24.1 & 242 & 219 & 73 & 33.3 \\
\hline North West & 6606 & 4949 & 1553 & 31.4 & 2949 & 2657 & 751 & 28.3 & 1619 & 1449 & 598 & 41.3 \\
\hline Western Cape & 10014 & 6470 & 2885 & 44.6 & 5262 & 4195 & 1626 & 38.8 & 3126 & 2683 & 1298 & 8.4 \\
\hline National & 100306 & 72033 & 23413 & 32.5 & 45590 & 39501 & 11886 & 30.1 & 24420 & 21930 & 8114 & 37.0 \\
\hline
\end{tabular}

Source: National Examinations Database, November 2013.

Note 1: The number of students who REGISTERED, WROTE and COMPLETED include only those who were eligible to complete an NC(V) qualification during the 2013 academic year.

Note 2: "Number registered" refers to the number of students who registered for the $2013 \mathrm{NC}(\mathrm{V})$ Levels 2 to 4 examinations and were eligible to complete an NC(V) qualification during the 2013 academic year. This number excludes students who registered to write individual subjects but who were not eligible to complete NC(V) Levels 2 to 4 qualifications in 2013.

Note 3: "Number wrote" refers to the number of students who wrote the $2013 \mathrm{NC}(\mathrm{V})$ Levels 2 to 4 examinations and were eligible to complete an NC(V) qualification during the 2013 academic year. This number excludes students who wrote individual subjects but who were not eligible to complete NC(V) Levels 2 to 4 qualifications in 2013.

Note 4: "Number completed" refers to the number of students who were eligible to complete and successfully completed NC(V) Levels 2 to 4 qualifications in the 2013 academic year. This number excludes students who may have passed individual subjects but were not eligible to complete NC(V) Levels 2 to 4 qualifications in 2013.

Note 5: "Completion rate" refers to the number of students who successfully completed an NC(V) qualification in the 2013 academic year, expressed as a percentage of the number of candidates who were eligible to complete NC(V) Levels 2 to 4 qualifications and wrote the examinations (the latter is defined above) in 2013.

Note 6: $\quad \mathrm{NC}(\mathrm{V})$ Level 2, NC(V) Level 3 and NC(V) Level 4 are all full qualifications.

Table 27 shows that in public FET/TVET Colleges in 2013, the average national completion rate for NC(V) Level 2 was 33\%, Level 3, 30\% and Level 4, 37\%. The largest proportion of students registered for examinations in the NC(V) Level 2 qualification. There is a significant difference in the number of students who were eligible to complete a qualification during the 2013 academic year in relation to the number of students who wrote and completed the qualification. For the $N C(V)$ Level 2 qualification, Mpumalanga had the highest completion rate at $45 \%$, compared with the Free State that had the lowest completion rate at $17 \%$. 
Table 28: Number of students in public FET/TVET Colleges who registered, wrote and completed Report 191 N1 to N3 qualifications for Engineering Studies, by province and programme, in 2013

\begin{tabular}{|c|c|c|c|c|c|c|c|c|c|c|c|c|}
\hline \multirow[b]{2}{*}{ Province } & \multicolumn{4}{|c|}{ Report 191 N1 } & \multicolumn{4}{|c|}{ Report 191 N2 } & \multicolumn{4}{|c|}{ Report 191 N3 } \\
\hline & 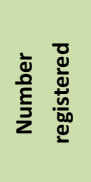 & 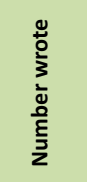 & 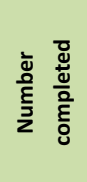 & 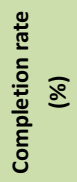 & 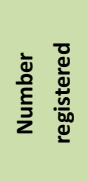 & 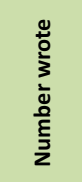 & 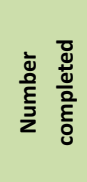 & $\begin{array}{l}\frac{ \pm}{\pi} \\
\frac{0}{0} \\
\frac{0}{0} \\
\frac{0}{0} \\
\frac{0}{0}\end{array}$ & 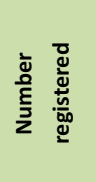 & 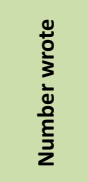 & 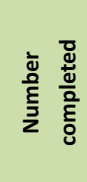 & 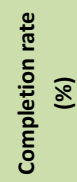 \\
\hline Eastern Cape & 2413 & 2229 & 1031 & 46.3 & 3371 & 3286 & 1595 & 48.5 & 2961 & 2863 & 1113 & 38.9 \\
\hline Free State & 3408 & 3313 & 1422 & 42.9 & 5039 & 4982 & 2079 & 41.7 & 2939 & 2895 & 1094 & 37.8 \\
\hline Gauteng & 9773 & 9368 & 4618 & 49.3 & 16468 & 16273 & 7279 & 44.7 & 14309 & 14071 & 6277 & 44.6 \\
\hline KwaZulu-Natal & 3940 & 3710 & 1689 & 45.5 & 8572 & 8447 & 3888 & 46.0 & 7437 & 7326 & 3719 & 50.8 \\
\hline Limpopo & 2417 & 2316 & 1273 & 55.0 & 5836 & 5775 & 2830 & 49.0 & 4592 & 4526 & 2008 & 44.4 \\
\hline Mpumalanga & 2342 & 2231 & 1083 & 48.5 & 5734 & 5666 & 3154 & 55.7 & 4263 & 4170 & 2117 & 50.8 \\
\hline Northern Cape & 587 & 545 & 239 & 43.9 & 1546 & 1527 & 706 & 46.2 & 337 & 330 & 113 & 34.2 \\
\hline North West & 3340 & 3140 & 1586 & 50.5 & 5990 & 5825 & 2625 & 45.1 & 2787 & 2682 & 1148 & 42.8 \\
\hline Western Cape & 3472 & 3308 & 1702 & 51.5 & 3777 & 3705 & 1694 & 45.7 & 2403 & 2338 & 794 & 34.0 \\
\hline National & 31692 & 30160 & 14643 & 48.6 & 56333 & 55486 & 25850 & 46.6 & 42028 & 41201 & 18383 & 44.6 \\
\hline
\end{tabular}

Source: National Examinations Database, November 2013.

Note 1: The number of students who REGISTERED, WROTE and COMPLETED include only those who were eligible to complete a Report 191 part-qualification during the 2013 academic year.

Note 2: "Number registered" refers to the number of students who registered for the 2013 Report 191 N1 to N3 examinations in Engineering Studies and were eligible to complete a Report 191 N1 to N3 part-qualification during the 2013 academic year. This number excludes students who registered to write individual subjects but who were not eligible to complete Report 191 N1 to N3 part-qualifications in 2013.

Note 3: "Number wrote" refers to the number of students who wrote the 2013 Report 191 N1 to N3 examinations in Engineering Studies and were eligible to complete a Report 191 N1 to N3 part-qualification during the 2013 academic year. This number excludes students who wrote individual subjects but who were not eligible to complete Report 191 N1 to N3 part-qualifications in 2013.

Note 4: "Number completed" refers to the number of students who were eligible to complete and successfully completed Report 191 N1 to N3 part-qualifications in the 2013 academic year. This number excludes students who may have passed individual subjects but who were not eligible to complete Report 191 N1 to N3 partqualifications in 2013.

Note 5: "Completion rate" refers to the number of students who successfully completed a Report 191 N1 to N3 part-qualification in the 2013 academic year, expressed as a percentage of the number of students who were eligible to complete Report $191 \mathrm{~N} 1$ to N3 part-qualifications and wrote the examinations (the latter is defined above) in 2013.

Note 6: The number of students who registered for, wrote and completed N1 to N3 part-qualifications for Engineering Studies include the consolidated numbers across all three trimesters of the 2013 academic year.

Table 28 shows that in public FET/TVET Colleges in 2013, the average national completion rate for Report 191 N1 to N3 Engineering Studies was as follows: N1, 49\%; N2, 47\%; and N3, 45\%. The largest proportion of students registered for examinations in the N2 part-qualification. There is a significant difference in the number of students who wrote and were eligible to complete a Report 191 part-qualification when compared with the number of students who completed the part-qualification. For the N2 Engineering Studies part-qualification, Mpumalanga had the highest completion rate at $56 \%$, compared with the Free State with the lowest completion rate at $42 \%$. 
Table 29: Number of students in public FET/TVET Colleges who registered, wrote and completed Report 191 N4 to N6 partqualifications for Engineering Studies, by province and programme, in 2013

\begin{tabular}{|c|c|c|c|c|c|c|c|c|c|c|c|c|}
\hline \multirow[b]{2}{*}{ Province } & \multicolumn{4}{|c|}{ Report 191 N4 } & \multicolumn{4}{|c|}{ Report 191 N5 } & \multicolumn{4}{|c|}{ Report 191 N6 } \\
\hline & 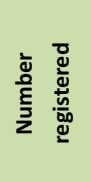 & 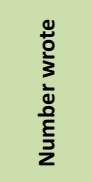 & 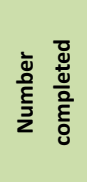 & 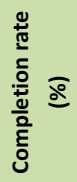 & 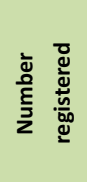 & 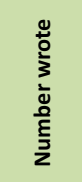 & 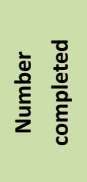 & $\begin{array}{l}\frac{ \pm}{\pi} \\
\frac{0}{0} \\
\frac{0}{0} \\
\frac{0}{0} \\
\frac{0}{0}\end{array}$ & 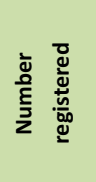 & 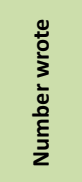 & 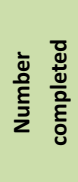 & 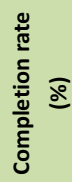 \\
\hline Eastern Cape & 2303 & 2205 & 1262 & 57.2 & 1847 & 1797 & 962 & 53.5 & 1460 & 1419 & 619 & 43.6 \\
\hline Free State & 2202 & 2181 & 1111 & 50.9 & 1614 & 1606 & 688 & 42.8 & 1093 & 1078 & 479 & 44.4 \\
\hline Gauteng & 11311 & 11078 & 5969 & 53.9 & 8717 & 8561 & 4539 & 53.0 & 6965 & 6847 & 3153 & 46.0 \\
\hline KwaZulu-Natal & 6314 & 6181 & 3515 & 56.9 & 4769 & 4695 & 2462 & 52.4 & 3472 & 3407 & 1689 & 49.6 \\
\hline Limpopo & 5709 & 5644 & 3046 & 54.0 & 5119 & 5067 & 2694 & 53.2 & 3105 & 3073 & 1394 & 45.4 \\
\hline Mpumalanga & 2530 & 2464 & 1288 & 52.3 & 1593 & 1543 & 759 & 49.2 & 1044 & 1007 & 469 & 46.6 \\
\hline Northern Cape & 192 & 191 & 94 & 49.2 & 170 & 158 & 77 & 48.7 & 118 & 116 & 65 & 56.0 \\
\hline North West & 1650 & 1574 & 826 & 52.5 & 1066 & 1012 & 514 & 50.8 & 693 & 675 & 270 & 40.0 \\
\hline Western Cape & 2015 & 1975 & 1054 & 53.4 & 1636 & 1591 & 879 & 55.2 & 1040 & 1020 & 473 & 46.4 \\
\hline National & 34226 & 33493 & 18165 & 54.2 & 26531 & 26030 & 13574 & 52.1 & 18990 & 18642 & 8611 & 46.2 \\
\hline
\end{tabular}

Source: National Examinations Database, November 2013.

Note 1: The number of students who REGISTERED, WROTE and COMPLETED include only those who were eligible to complete a Report 191 part-qualification during the 2013 academic year.

Note 2: "Number registered" refers to the number of students who registered for the 2013 Report 191 N4 to N6 examinations in Engineering Studies and were eligible to complete a Report 191 N4 to N6 part-qualification during the 2013 academic year. This number excludes students who registered to write individual subjects but who were not eligible to complete Report 191 N4 to N6 part-qualifications in 2013.

Note 3: "Number wrote" refers to the number of students who wrote the 2013 Report 191 N4 to N6 examinations in Engineering Studies and were eligible to complete a Report 191 N4-N6 part-qualification during the 2013 academic year. This number excludes students who wrote individual subjects but who were not eligible to complete Report 191 N4 to N6 part-qualifications in 2013.

Note 4: "Number completed" refers to the number of students who were eligible to complete and successfully completed Report 191 N4 to N6 part-qualifications in the 2013 academic year. This number excludes students who may have passed individual subjects but who were not eligible to complete Report 191 N4 to N6 partqualifications in 2013.

Note 5: "Completion rate" refers to the number of students who successfully completed a Report 191 N4 to N6 part-qualification in the 2013 academic year, expressed as a percentage of the number of students who were eligible to complete Report 191 N4 to N6 part-qualifications and wrote the examinations (the latter is defined above) in 2013.

Note 6: The number of students who registered for, wrote and completed N4 to N6 part-qualifications for Engineering Studies include the consolidated numbers across all three trimesters of the 2013 academic year.

Table 29 shows that in public FET/TVET Colleges in 2013, the average national completion rate for Report 191 N4 to N6 Engineering Studies was as follows: N4, 54\%; N5, 52\%; and N6, 46\%. The largest proportion of students registered for examinations in the N4 part-qualification. For the N4 Engineering Studies examinations, the Eastern Cape and KwaZulu-Natal had the highest completion rate at $57 \%$, compared with the Northern Cape with the lowest completion rate at $49 \%$. There is a significant difference in the number of students who wrote and were eligible to complete a Report 191 N4 to N6 part-qualification for Engineering Studies when compared with the number of students who completed the part-qualification. 
Table 30: Number of students in public FET/TVET Colleges who registered, wrote and completed Report 191 N4 to N6 partqualifications for Business Studies, by province and programme, in 2013

\begin{tabular}{|c|c|c|c|c|c|c|c|c|c|c|c|c|}
\hline \multirow[b]{2}{*}{ Province } & \multicolumn{4}{|c|}{ Report 191 N4 } & \multicolumn{4}{|c|}{ Report 191 N5 } & \multicolumn{4}{|c|}{ Report 191 N6 } \\
\hline & 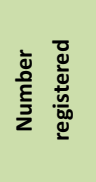 & 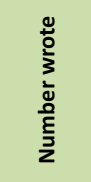 & 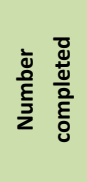 & 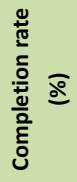 & 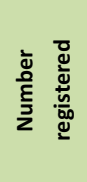 & 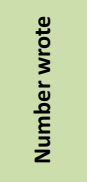 & 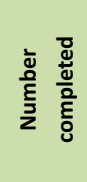 & 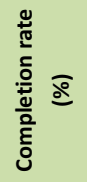 & 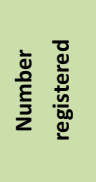 & 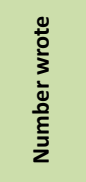 & 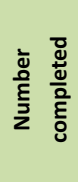 & 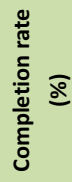 \\
\hline Eastern Cape & 7590 & 7248 & 2639 & 36.4 & 4364 & 4129 & 1204 & 29.2 & 2439 & 2316 & 561 & 24.2 \\
\hline Free State & 9918 & 9404 & 2442 & 26.0 & 4791 & 4546 & 1308 & 28.8 & 2799 & 2697 & 782 & 29.0 \\
\hline Gauteng & 15255 & 14547 & 5535 & 38.0 & 10337 & 9919 & 3170 & 32.0 & 6239 & 6023 & 1758 & 29.2 \\
\hline KwaZulu-Natal & 16249 & 15186 & 4635 & 30.5 & 10216 & 9802 & 3631 & 37.0 & 5938 & 5765 & 1545 & 26.8 \\
\hline Limpopo & 8577 & 8402 & 2577 & 30.7 & 4211 & 4093 & 1130 & 27.6 & 2586 & 2467 & 477 & 19.3 \\
\hline Mpumalanga & 1680 & 1615 & 531 & 32.9 & 1577 & 1511 & 322 & 21.3 & 905 & 866 & 175 & 20.2 \\
\hline Northern Cape & 1508 & 1426 & 340 & 23.8 & 1388 & 1330 & 337 & 25.3 & 625 & 600 & 138 & 23.0 \\
\hline North West & 3725 & 3541 & 1167 & 33.0 & 2194 & 2066 & 704 & 34.1 & 1191 & 1112 & 361 & 32.5 \\
\hline Western Cape & 5812 & 5426 & 2523 & 46.5 & 4707 & 4477 & 2119 & 47.3 & 2420 & 2353 & 860 & 36.5 \\
\hline National & 70314 & 66795 & 22389 & 33.5 & 43785 & 41873 & 13925 & 33.3 & 25142 & 24199 & 6657 & 27.5 \\
\hline
\end{tabular}

Source: National Examinations Database, November 2013.

Note 1: The number of students who REGISTERED, WROTE and COMPLETED include only those who were eligible to complete a Report 191 part-qualification during the 2013 academic year.

Note 2: "Number registered" refers to the number of students who registered for the 2013 Report 191 N4 to N6 examinations in Business Studies and were eligible to complete a Report $191 \mathrm{~N} 4$ to N6 part-qualification during the 2013 academic year. This number excludes students who registered to write individual subjects but who were not eligible to complete Report 191 N4 to N6 part-qualifications in 2013.

Note 3: "Number wrote" refers to the number of students who wrote the 2013 Report 191 N4 to N6 examinations in Business Studies and were eligible to complete a Report 191 N4 to N6 part-qualification during the 2013 academic year. This number excludes students who wrote individual subjects but who were not eligible to complete Report 191 N4 to N6 part-qualifications in 2013.

Note 4: "Number completed" refers to the number of students who were eligible to complete and successfully completed Report 191 N4 to N6 part-qualifications in the 2013 academic year. This number excludes students who may have passed individual subjects but who were not eligible to complete Report 191 N4 to N6 partqualifications in 2013.

Note 5: "Completion rate" refers to the number of students who successfully completed a Report 191 N4 to N6 part-qualification in the 2013 academic year, expressed as a percentage of the number of students who were eligible to complete Report 191 N4 to N6 part-qualifications and wrote the examinations (the latter is defined above) in 2013.

Note 6: The number of students who registered for, wrote and completed N4 to N6 part-qualifications for Business Studies include the consolidated numbers across both semesters of the 2013 academic year.

Table 30 shows that in public FET/TVET Colleges in 2013, the average national completion rate for Report 191 N4 to N6 Business Studies was as follows: N4, 34\%; N5, 33\%; and N6, 28\%. The largest proportion of students registered for examinations in the N4 part-qualification. There is a significant difference in the number of students who wrote and were eligible to complete a Report 191 N4 to N6 part-qualification for Business Studies when compared with the number of students who completed the part-qualification. For the N4 Business Studies examinations, the Western Cape had the highest completion rate at $47 \%$, compared with the Northern Cape with the lowest completion rate at $24 \%$. 
Table 31: Number of students in public FET/TVET Colleges who registered, wrote and completed the NC(V) Level 4 qualification, by programme and gender, in 2013

\begin{tabular}{|c|c|c|c|c|c|c|c|c|c|}
\hline \multirow[b]{2}{*}{$\mathrm{NC}(\mathrm{V})$ Level 4 Programme } & \multicolumn{3}{|c|}{ Female } & \multicolumn{3}{|c|}{ Male } & \multirow[b]{2}{*}{ 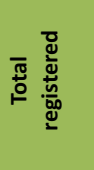 } & \multirow[b]{2}{*}{ 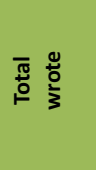 } & \multirow{2}{*}{ 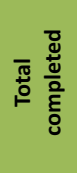 } \\
\hline & 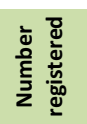 & 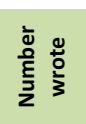 & 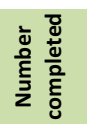 & 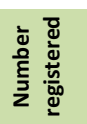 & 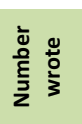 & 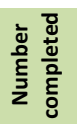 & & & \\
\hline L4:Civil Engineering and Building Construction & 564 & 512 & 125 & 1175 & 998 & 273 & 1739 & 1510 & 398 \\
\hline L4:Education and Development & 410 & 376 & 237 & 68 & 55 & 26 & 478 & 431 & 263 \\
\hline L4:Electrical Infrastructure Construction & 1149 & 1066 & 320 & 1802 & 1616 & 458 & 2951 & 2682 & 778 \\
\hline L4:Engineering and Related Design & 718 & 664 & 130 & 2114 & 1869 & 463 & 2832 & 2533 & 593 \\
\hline L4:Finance, Economics and Accounting & 1312 & 1221 & 353 & 625 & 572 & 153 & 1937 & 1793 & 506 \\
\hline L4:Hospitality & 958 & 869 & 323 & 339 & 300 & 106 & 1297 & 1169 & 429 \\
\hline L4:Information Technology and Computer Studies & 630 & 577 & 112 & 747 & 650 & 142 & 1377 & 1227 & 254 \\
\hline L4:Management & 853 & 775 & 337 & 401 & 352 & 162 & 1254 & 1127 & 499 \\
\hline L4:Marketing & 786 & 720 & 296 & 497 & 418 & 145 & 1283 & 1138 & 441 \\
\hline L4:Mechatronics & 67 & 67 & 21 & 127 & 124 & 35 & 194 & 191 & 56 \\
\hline L4:Office Administration & 4955 & 4476 & 2149 & 1383 & 1209 & 515 & 6338 & 5685 & 2664 \\
\hline L4:Primary Agriculture & 357 & 335 & 86 & 243 & 214 & 69 & 600 & 549 & 155 \\
\hline L4:Process Plant Operations & 31 & 28 & 12 & 17 & 16 & 8 & 48 & 44 & 20 \\
\hline L4:Safety In Society & 515 & 441 & 225 & 406 & 348 & 163 & 921 & 789 & 388 \\
\hline L4:Tourism & 739 & 680 & 442 & 432 & 382 & 228 & 1171 & 1062 & 670 \\
\hline Total & 14044 & 12807 & 5168 & 10376 & 9123 & 2946 & 24420 & 21930 & 8114 \\
\hline
\end{tabular}

Source: National Examinations Database, November 2013.

Note 1: The number of students who REGISTERED, WROTE and COMPLETED include only those who were eligible to complete an NC(V) qualification during the 2013 academic year.

Note 2: "Number registered" refers to the number of students who registered for the $2013 \mathrm{NC}(\mathrm{V})$ Level 4 examinations and were eligible to complete an NC(V) qualification during the 2013 academic year. This number excludes students who registered to write individual subjects but who were not eligible to complete the NC(V) Level 4 qualification in 2013 .

Note 3: "Number wrote" refers to the number of students who wrote the $2013 \mathrm{NC}(\mathrm{V})$ Level 4 examinations and were eligible to complete an NC(V) qualification during the 2013 academic year. This number excludes students who wrote individual subjects but who were not eligible to complete the NC(V) Level 4 qualification in 2013.

Note 4: "Number completed" refers to the number of students who were eligible to complete and successfully completed the NC(V) Level 4 qualification in the 2013 academic year. This number excludes students who may have passed individual subjects but who were not eligible to complete the NC(V) Level 4 qualification in 2013.

Note 5: "Completion rate" refers to the number of students who successfully completed an NC(V) qualification in the 2013 academic year, expressed as a percentage of the number of students who were eligible to complete the NC(V) Level 4 qualification and wrote the examinations (the latter is defined above) in 2013.

Note 6: $\mathrm{NC}(\mathrm{V})$ Level 4 is a full qualification.

Table 31 shows that in public FET/TVET Colleges in 2013, more than 24000 students registered for examinations in the $\mathrm{NC}(\mathrm{V})$ Level 4 qualification. The majority of students were female. Most female students registered for the Office Administration programme (5000), whereas the majority of male students registered for Engineering and Related Design programmes (2 100). Only 48 students registered for the Process Plant Operations programme. Table 31 also indicates a significant difference in the number of students who wrote and were eligible to complete the NC(V) Level 4 qualification compared with the number of students who completed the qualification. 
Table 32: Number of students in public FET/TVET Colleges who registered, wrote and completed the Report 191 N6 partqualification, by programme and gender, in 2013

\begin{tabular}{|c|c|c|c|c|c|c|c|c|c|}
\hline \multirow[b]{2}{*}{ Report 191 N6 Programmes } & \multicolumn{3}{|c|}{ Female } & \multicolumn{3}{|c|}{ Male } & \multirow{2}{*}{ 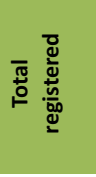 } & \multirow[b]{2}{*}{ 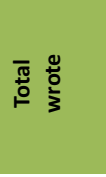 } & \multirow{2}{*}{ 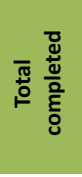 } \\
\hline & 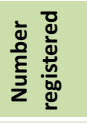 & 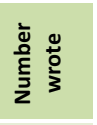 & 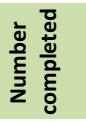 & 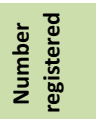 & 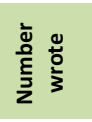 & 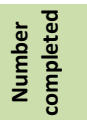 & & & \\
\hline N6:Art and Design & 43 & 39 & 30 & 80 & 79 & 40 & 123 & 118 & 70 \\
\hline N6:Business Management & 3632 & 3443 & 593 & 1527 & 1457 & 284 & 5159 & 4900 & 877 \\
\hline N6:Clothing Production & 85 & 76 & 37 & 17 & 16 & 6 & 102 & 92 & 43 \\
\hline N6:Educare & 717 & 705 & 341 & 22 & 22 & 8 & 739 & 727 & 349 \\
\hline N6:Engineering Studies & 6720 & 6634 & 3001 & 12270 & 12008 & 5610 & 18990 & 18642 & 8611 \\
\hline N6:Farming Management & 49 & 48 & 15 & 66 & 62 & 14 & 115 & 110 & 29 \\
\hline N6:Financial Management & 2983 & 2875 & 772 & 1284 & 1243 & 359 & 4267 & 4118 & 1131 \\
\hline N6:Hospitality and Catering Services & 405 & 401 & 130 & 116 & 113 & 24 & 521 & 514 & 154 \\
\hline N6:Human Resources Management & 4064 & 3932 & 932 & 1626 & 1553 & 461 & 5690 & 5485 & 1393 \\
\hline N6:Legal Secretary & 4 & 4 & 1 & 1 & 1 & 0 & 5 & 5 & 1 \\
\hline N6:Management Assistant & 2734 & 2624 & 1066 & 552 & 507 & 190 & 3286 & 3131 & 1256 \\
\hline N6:Marketing Management & 1376 & 1347 & 268 & 1022 & 996 & 228 & 2398 & 2343 & 496 \\
\hline N6:Popular Music: Performance & 12 & 12 & 6 & 11 & 11 & 6 & 23 & 23 & 12 \\
\hline N6:Popular Music: Studio Work & 3 & 3 & 0 & 17 & 15 & 9 & 20 & 18 & 9 \\
\hline N6:Public Management & 1183 & 1150 & 390 & 496 & 480 & 164 & 1679 & 1630 & 554 \\
\hline N6:Public Relations & 456 & 440 & 93 & 168 & 163 & 39 & 624 & 603 & 132 \\
\hline N6:Tourism & 249 & 241 & 109 & 142 & 141 & 42 & 391 & 382 & 151 \\
\hline Total & 24715 & 23974 & 7784 & 19417 & 18867 & 7484 & 44132 & 42841 & 15268 \\
\hline
\end{tabular}

Source: National Examinations Database, November 2013

Note 1: The number of students who REGISTERED, WROTE and COMPLETED include only those who were eligible to complete an N6 part-qualification during the 2013 academic year.

Note 2: "Number registered" refers to the number of students who registered for the 2013 Report 191 N6 examinations and were eligible to complete a Report 191 N6 partqualification during the 2013 academic year. This number excludes students who registered to write individual subjects but who were not eligible to complete the N6 part-qualification in 2013.

Note 3: "Number wrote" refers to the number of students who wrote the 2013 Report 191 N6 examinations and were eligible to complete a Report 191 N6 partqualification during the 2013 academic year. This number excludes students who wrote individual subjects but who were not eligible to complete the Report $191 \mathrm{~N} 6$ part-qualification in 2013.

Note 4: "Number completed" refers to the number of students who were eligible to complete and successfully completed the Report 191 N6 part-qualification in the 2013 academic year. This number excludes students who may have passed individual subjects but who were not eligible to complete the Report $191 \mathrm{~N} 6$ part-qualification in 2013.

Note 5: "Completion rate" refers to the number of students who successfully completed a Report 191 N6 part-qualification in the 2013 academic year, expressed as a percentage of the number of students who were eligible to complete the Report $191 \mathrm{~N} 6$ part-qualification and wrote the examinations (the latter is defined above) in 2013.

Table 32 shows that in public FET/TVET Colleges in 2013, more than 44000 students registered for examinations in the Report 191 N6 part-qualification. However, only 15000 students completed the N6 part-qualification. The table also indicates that more female than male students registered for the N6 part-qualification. Most students registered for the N6 Engineering Studies programme at 18 990. The number comprised 6700 female students and 12000 male students. With five students, the Legal Secretary programme had the lowest number of registered students. 


\subsection{PRIVATE FET COLLEGES}

\subsubsection{Introduction}

The information reflected in this section is derived from private FET Colleges registered with the Department that responded to the departmental Annual Survey. It includes statistics on headcount enrolment per qualification category and gender. Staffing is reflected by staff category and gender.

In 2013, 627 private FET Colleges were registered with the Department. However, only 503 private FET Colleges responded to the Annual Survey sent to them by the Department. Therefore, the data provided below must be read in this context.

This information provides an insight into the contribution of private FET College delivery to the system as a whole, while the examination data reveals interesting information related to the performance of the system.

\subsubsection{Overview of the private FET sector}

Table 33: Number of lecturers and students in private FET Colleges, by province, in 2013

\begin{tabular}{|c|c|c|}
\hline Province & Lecturers & Students \\
\hline Eastern Cape & 169 & 10619 \\
\hline Free State & 35 & 1524 \\
\hline Gauteng & 1208 & 69363 \\
\hline KwaZulu-Natal & 501 & 17621 \\
\hline Limpopo & 116 & 3830 \\
\hline Mpumalanga & 102 & 5944 \\
\hline Northern Cape & 3 & 200 \\
\hline North West & 69 & 1974 \\
\hline Western Cape & 776 & 32738 \\
\hline Unspecified & 203 & 10819 \\
\hline National & 3182 & 154632 \\
\hline
\end{tabular}

Source: 2013 Annual Survey of Private FET Colleges 20140726.

Table 33 shows that, in 2013, the private FET College sector had more than 3000 lecturing staff servicing 155000 students. The majority of the lecturing staff and students were in Gauteng, 1200 lecturers for 69000 students. The Northern Cape had three lecturers for 200 students in 2013. 


\subsubsection{Enrolment in private FET Colleges}

Figure 11: Number of students enrolled in private FET Colleges, by qualification category, from 2010 to 2013

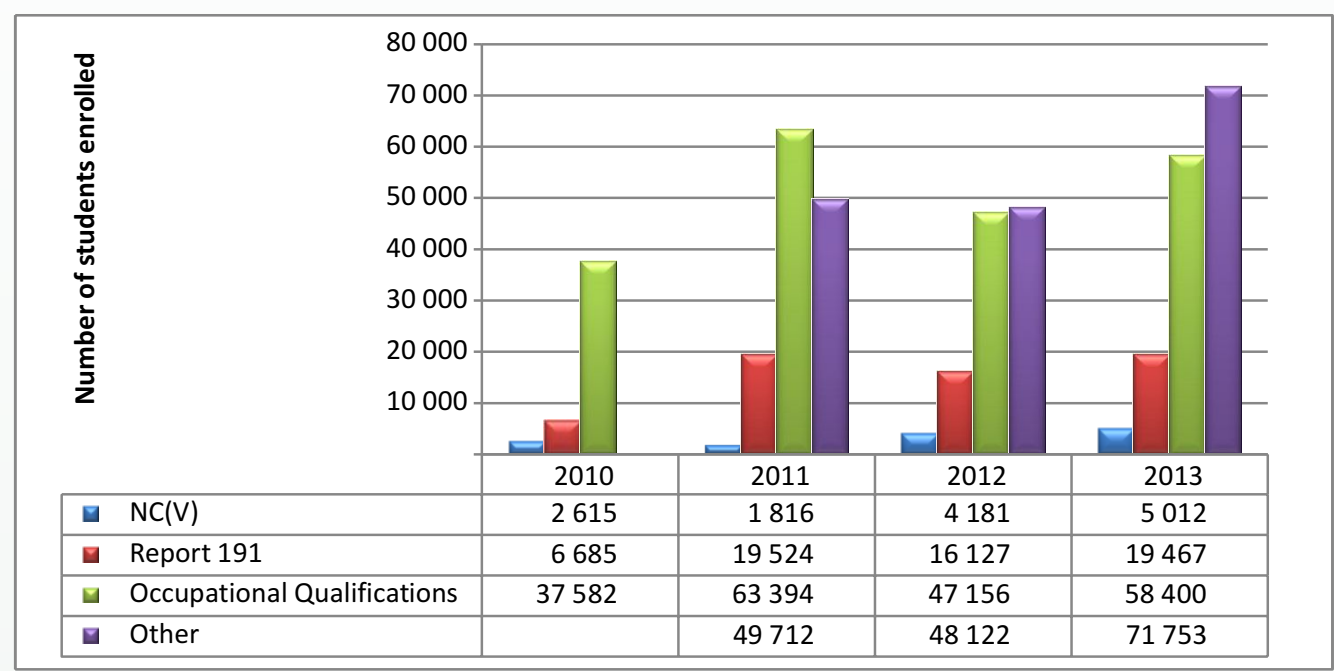

Source: 2013 Annual Survey of Private FET Colleges 20140726.

Figure 11 shows that student enrolment in all qualification categories increased from 2010 to 2013 . NC(V) enrolment increased from 2600 in 2010 to 5000 in 2013, Report 191 enrolment increased from 6700 in 2010 to 19500 in 2013 and occupational qualifications from 37500 in 2010 to 58500 in 2013.

Table 34: Number of students enrolled in private FET Colleges, by qualification category and gender, in 2013

\begin{tabular}{|c|c|c|c|}
\hline Qualification Category & Female & Male & Total \\
\hline$N C(V)$ Levels 2 to 4 & 3018 & 1994 & 5012 \\
\hline Report 191 (N1 to N3) & 6129 & 6488 & 12617 \\
\hline Report 191 (N4 to N6) & 2756 & 4094 & 6850 \\
\hline Occupational Qualifications & 32804 & 25596 & 58400 \\
\hline Other & 44570 & 27183 & 71753 \\
\hline Total & 89277 & 65355 & 154632 \\
\hline
\end{tabular}

Source: 2013 Annual Survey of Private FET Colleges 20140726.

Note 1: $\mathrm{NC}(\mathrm{V})$ refers to the National Certificate (Vocational).

Note 2: Report 191 refers to NATED programmes, N1 to N6.

Note 3: "Occupational Qualifications" refer to qualifications associated with a trade, occupation or profession resulting from work-based learning, and consisting of knowledge unit standards, practical unit standards and work experience unit standards.

Note 4: "Other" in FET/TVET Colleges refers to all other skills development and short courses.

Table 34 shows that more than 154000 students enrolled in private FET Colleges in 2013. Of these, the majority were female at 89 000. Most students in private FET Colleges enrolled for "other" and occupational qualifications at 71753 and 58 400, respectively. The lowest number of students in private FET Colleges enrolled for NC(V) Levels 2 to 4 qualifications. 
Table 35: Number of students in private FET Colleges, by organising fields, in 2013

\begin{tabular}{|c|c|c|}
\hline Number & Programmes for organising fields & Total \\
\hline 1 & Agriculture and Nature Conservation & 1735 \\
\hline 2 & Business, Commerce and Management Studies & 28672 \\
\hline 3 & Communication Studies and Languages & 672 \\
\hline 4 & Culture and Arts & 50 \\
\hline 5 & Education, Training and Development & 11454 \\
\hline 6 & Health Sciences and Social Services & 8294 \\
\hline 7 & Human and Social Studies & 590 \\
\hline 8 & Law, Military Science and Security & 40 \\
\hline 9 & Manufacturing, Engineering and Technology & 5543 \\
\hline 10 & Physical Planning and Construction & 787 \\
\hline 11 & Physical, Mathematical, Computer and Life Sciences & 4956 \\
\hline 12 & Services & 4009 \\
\hline Total & & 66802 \\
\hline
\end{tabular}

Source: 2013 Annual Survey of Private FET Colleges 20140726.

The majority of the students in private FET Colleges (almost 29000 ) had enrolled in the Business, Commerce and Management Studies organising fields, while only 40 students enrolled for the Law, Military Science and Security field of study.

\subsubsection{Staffing in private FET Colleges}

Table 36: Number of staff in private FET Colleges, by category and gender, in 2013

\begin{tabular}{|l|r|r|r|r|}
\hline Staff Category & Female & & Male & \multicolumn{1}{|c|}{ Total } \\
\hline Management Staff & 670 & 524 & 1194 \\
\hline Lecturing Staff & 1563 & $\mathbf{3 1 9 2}$ \\
\hline Support Staff & 2404 & 1159 & $\mathbf{3 5 6 2}$ \\
\hline Total & $\mathbf{4 6 3 7}$ & $\mathbf{3 9 3 9}$ \\
\hline
\end{tabular}

Source: 2013 Annual Survey of Private FET Colleges 20140726.

Note 1: The category "Management Staff" refers to the principal and vice-principal of a private FET College.

Note 2: The category "Lecturing Staff" refers to any person who teaches, educates or trains other persons, or who provides professional educational services at any College, and who is appointed in a post at any lecturing establishment.

Note 3: The category "Support Staff" refers to all other staff who are not teaching. This includes persons who render: academic support services; student/learner support services; human resource management; financial management; administration; maintenance of buildings and gardens; catering services; and security services.

Table 36 indicates that private FET Colleges employed more than 7900 staff in 2013. Most staff were employed in the support staff category (3 500 staff). The table also shows that there were more female than male staff. 


\subsubsection{Examination results in private FET Colleges}

Table 37: Number of students in private FET Colleges who registered, wrote and completed national qualifications, by qualification category and gender, in 2013

\begin{tabular}{|c|c|c|c|c|c|c|c|c|c|}
\hline \multirow[b]{2}{*}{ Qualification Category } & \multicolumn{3}{|c|}{ Female } & \multicolumn{3}{|c|}{ Male } & \multirow{2}{*}{ 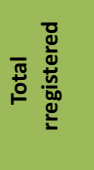 } & \multirow[b]{2}{*}{ 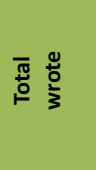 } & \multirow{2}{*}{ 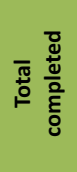 } \\
\hline & 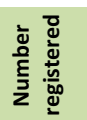 & 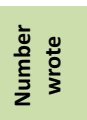 & 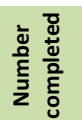 & 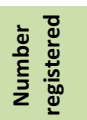 & 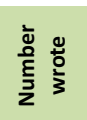 & 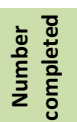 & & & \\
\hline Report 191 (N3) & 9495 & 9409 & 2879 & 15366 & 15178 & 4924 & 24861 & 24587 & 7803 \\
\hline Report 191 (N3) & 4490 & 4218 & 1280 & 5177 & 4993 & 2036 & 9667 & 9211 & 3316 \\
\hline NC(V) Level 4 & 381 & 328 & 161 & 250 & 212 & 71 & 631 & 540 & 232 \\
\hline Total & 14366 & 13955 & 4320 & 20793 & 20383 & 7031 & 35159 & 34338 & 11351 \\
\hline
\end{tabular}

Source: National Examinations Database, November 2013.

Note 1: The number of students who REGISTERED, WROTE and COMPLETED include only those who were eligible to complete qualifications (part or full) during the 2013 academic year.

Note 2: "Number registered" refers to the number of students who registered for the relevant examinations in 2013 and were eligible to complete the relevant qualifications during the 2013 academic year. This number excludes students who registered to write individual subjects but who were not eligible to complete the relevant qualifications in 2013.

Note 3: "Number wrote" refers to the number of students who wrote the relevant examinations in 2013 and were eligible to complete the relevant qualifications during the 2013 academic year. This number excludes students who wrote individual subjects but who were not eligible to complete the relevant qualifications in 2013.

Note 4: "Number completed" refers to the number of students who were eligible to complete and successfully completed the relevant qualifications in the 2013 academic year. This number excludes students who may have passed individual subjects but who were not eligible to complete the relevant qualifications in 2013.

Table 37 shows that in private FET Colleges in 2013, more than 35000 students registered for examinations in Report 191 (N3 and N6) part-qualifications and NC(V) Level 4 qualifications. Most students registered for the N3 partqualification at 25000 and the qualification with the lowest number of registered students was NC(V) Level 4 at 631. Just over 34000 students wrote examinations in NC(V) Level 4 qualifications and Report 191 N3 and N6 partqualifications, but only about 11000 students completed the qualifications.

The table also shows that more male than female students registered for N3 and N6 part-qualifications, whereas more female than male students registered for NC(V) Level 4 qualifications.

Table 38: Number of students in private FET Colleges who registered, wrote and completed NC(V) qualifications, by level, in 2013

\begin{tabular}{|l|r|r|r|r|}
\hline Qualification & Number registered & Number wrote & Number completed \\
\hline NC(V) Level 2 & 3314 & 2109 & 932 \\
\hline NC(V) Level 3 & 1221 & 976 & 341 \\
\hline NC(V) Level 4 & 631 & 540 & $\mathbf{4 4 . 2}$ \\
\hline Total & $\mathbf{5 1 6 6}$ & $\mathbf{3 6 2 5}$ & $\mathbf{3 4 . 9}$ \\
\hline
\end{tabular}

Source: National Examinations Database, November 2013.

Note 1: The number of students who REGISTERED, WROTE and COMPLETED include only those who were eligible to complete an NC(V) qualification during the 2013 academic year.

Note 2: "Number registered" refers to the number of students who registered for the $2013 \mathrm{NC}(\mathrm{V})$ Levels 2 to 4 examinations and were eligible to complete an NC(V) qualification during the 2013 academic year. This number excludes students who registered to write individual subjects but who were not eligible to complete $\mathrm{NC}(\mathrm{V})$ Levels 2 to 4 qualifications in 2013.

Note 3: "Number wrote" refers to the number of students who wrote the $2013 \mathrm{NC}(\mathrm{V})$ Levels 2 to 4 examinations and were eligible to complete an NC(V) qualification during the 2013 academic year. This number excludes students who wrote individual subjects but who were not eligible to complete NC(V) Levels 2 to 4 qualifications in 2013.

Note 4: "Number completed" refers to the number of students who were eligible to complete and successfully completed NC(V) Levels 2 to 4 qualifications in the 2013 academic year. This number excludes students who may have passed individual subjects but who were not eligible to complete NC(V) Levels 2 to 4 qualifications in 2013.

Note 5: "Completion rate" refers to the number of students who successfully completed an NC(V) qualification in the 2013 academic year, expressed as a percentage of the number of candidates who were eligible to complete NC(V) Levels 2 to 4 qualifications and wrote the examinations (the latter is defined above) in 2013. 
Table 38 shows that in private FET Colleges in 2013, more than 5000 students registered for NC(V) Levels 2 to 4 qualifications. More students registered for examinations in the $\mathrm{NC}(\mathrm{V})$ Level 2 qualification, compared with $\mathrm{NC}(\mathrm{V})$ Level 4. Close to 3600 students wrote and were eligible to complete $N C(V)$ qualifications, but only about 1500 students completed their qualifications. The average completion rate in private FET Colleges for the $\mathrm{NC}(\mathrm{V})$ qualification was $42 \%$.

Table 39: Number of students in private FET Colleges who registered, wrote and completed Report 191 N1 to N3 partqualifications for Engineering Studies, by programme, in 2013

\begin{tabular}{|l|r|r|r|r|}
\hline Programme & Number registered & Number wrote & Number completed \\
\hline Report 191 N1 & 4935 & 4673 & 2128 \\
\hline Report 191 N2 & 13271 & 13088 & 4546 \\
\hline Report 191 N3 & 24861 & 24587 & $\mathbf{4 5 . 5}$ \\
\hline Total & $\mathbf{4 3 0 6 7}$ & $\mathbf{3 4 . 7}$ \\
\hline
\end{tabular}

Source: National Examinations Database, November 2013.

Note 1: The number of students who REGISTERED, WROTE and COMPLETED include only those who were eligible to complete a Report 191 part-qualification during the 2013 academic year.

Note 2: "Number registered" refers to the number of students who registered for the 2013 Report 191 N1 to N3 examinations in Engineering Studies and were eligible to complete a Report 191 N1 to N3 part-qualification during the 2013 academic year. This number excludes students who registered to write individual subjects but who were not eligible to complete Report 191 N1 to N3 part-qualifications in 2013.

Note 3: "Number wrote" refers to the number of students who wrote the 2013 Report 191 N1 to N3 examinations in Engineering Studies and were eligible to complete a Report 191 N1 to N3 part-qualification during the 2013 academic year. This number excludes students who wrote individual subjects but who were not eligible to complete Report $191 \mathrm{~N} 1$ to N3 part-qualifications in 2013.

Note 4: "Number completed" refers to the number of students who were eligible to complete and successfully completed Report 191 N1 to N3 part-qualifications in the 2013 academic year. This number excludes students who may have passed individual subjects but who were not eligible to complete Report 191 N1 to N3 partqualifications in 2013.

Note 5: "Completion rate" refers to the number of students who successfully completed a Report 191 N1 to N3 part-qualification in the 2013 academic year, expressed as a percentage of the number of students who were eligible to complete the Report $191 \mathrm{~N} 1$ to N3 part-qualifications and wrote the examinations (the latter is defined above) in 2013.

Note 6: The number of students who registered for, wrote and completed N1 to N3 part-qualifications for Engineering Studies include the consolidated numbers across all three trimesters of the 2013 academic year.

Table 39 shows that in private FET Colleges in 2013, more than 43000 students registered for examinations in Report 191 N1 to N3 part-qualifications. The majority of students registered for the N3 part-qualification and the lowest number of students registered for the N1 part-qualification. The average completion rate in private FET Colleges for Report 191 N1 to N3 part-qualifications was 34\%. 
Table 40: Number of students in private FET Colleges who registered, wrote and completed Report 191 N4 to N6 partqualifications for Engineering Studies, by programme, in 2013

\begin{tabular}{|l|r|r|r|r|}
\hline Qualification & Number registered & Number wrote & Number completed \\
\hline Report 191 N4 & 15612 & 15387 & 6361 \\
\hline Report 191 N5 & 9692 & 9555 & 4180 & $\mathbf{4 1 . 3}$ \\
\hline Report 191 N6 & 6156 & 6079 & $\mathbf{4 3 . 7}$ \\
\hline Total & $\mathbf{3 1 4 6 0}$ & $\mathbf{3 1 0 2 1}$ & $\mathbf{4 3 . 1}$ \\
\hline
\end{tabular}

Source: National Examinations Database, November 2013.

Note 1: The number of students who REGISTERED, WROTE and COMPLETED include only those who were eligible to complete Report 191 N4 to N6 part-qualifications during the 2013 academic year.

Note 2: "Number registered" refers to the number of students who registered for the 2013 Report 191 N4 to N6 examinations and were eligible to complete a Report 191 N4 to N6 part-qualifications during the 2013 academic year. This number excludes students who registered to write individual subjects but who were not eligible to complete N4 to N6 part-qualifications in 2013.

Note 3: "Number wrote" refers to the number of students who wrote the 2013 Report 191 N6 examinations and were eligible to complete Report 191 N4 to N6 partqualifications during the 2013 academic year. This number excludes students who wrote individual subjects but who were not eligible to complete Report 191 N4 to N6 part-qualifications in 2013.

Note 4: "Number completed" refers to the number of students who were eligible to complete and successfully completed Report 191 N4 to N6 part-qualifications in the 2013 academic year. This number excludes students who may have passed individual subjects but who were not eligible to complete Report 191 N4 to N6 partqualifications in 2013.

Note 5: "Completion rate" refers to the number of students who successfully completed Report 191 N4 to N6 part-qualifications in the 2013 academic year, expressed as a percentage of the number of students who were eligible to complete Report 191 N4 to N6 part-qualifications and wrote the examinations (the latter is defined above) in 2013.

Note 6: The number of students who registered for, wrote and completed N4 to N6 part-qualifications for Engineering Studies include the consolidated numbers across al three trimesters of the 2013 academic year.

Table 40 shows that in private FET Colleges in 2013, more than 31000 students registered for N4 to N6 part-qualifications for Engineering Studies. The majority of students registered for examinations in the N4 part-qualification at almost 16000 students, and the lowest number of students registered for the N6 part-qualification (about 6000 students). The average completion rate in private FET Colleges for N4 to N6 part-qualifications in Engineering Studies was 42\%. 
Table 41: Number of students in private FET Colleges who registered, wrote and completed Report 191 N4 to N6 partqualifications for Business Studies, by programme, in 2013

\begin{tabular}{|l|r|r|r|r|}
\hline Qualification & Number registered & Number wrote & Number completed & Completion rate (\%) \\
\hline Report 191 N4 & 11316 & 10454 & 2421 & 1226 \\
\hline Report 191 N5 & 6119 & 5440 & $\mathbf{2 3 . 2}$ \\
\hline Report 191 N6 & 3511 & 3132 & $\mathbf{2 2 . 5}$ \\
\hline Total & $\mathbf{2 0 9 4 6}$ & $\mathbf{1 9} 026$ & $\mathbf{4 3 4 2}$ & $\mathbf{2 2 . 2}$ \\
\hline
\end{tabular}

Source: National Examinations Database, November 2013.

Note 1: The number of students who REGISTERED, WROTE and COMPLETED include only those who were eligible to complete Report 191 N4 to N6 part-qualifications during the 2013 academic year.

Note 2: "Number registered" refers to the number of students who registered for the 2013 Report 191 N4 to N6 examinations in Business Studies and were eligible to complete Report 191 N4 to N6 part-qualifications during the 2013 academic year. This number excludes students who registered to write individual subjects but who were not eligible to complete Report 191 N4 to N6 part-qualifications in 2013.

Note 3: "Number wrote" refers to the number of students who wrote the 2013 Report 191 N4 to N6 examinations for Business Studies and were eligible to complete Report 191 N4 to N6 part-qualifications during the 2013 academic year. This number excludes students who wrote individual subjects but who were not eligible to complete Report 191 N4 to N6 part-qualifications in 2013.

Note 4: "Number completed" refers to the number of students who were eligible to complete and successfully completed Report 191 N4 to N6 part-qualifications in the 2013 academic year. This number excludes students who may have passed individual subjects but who were not eligible to complete Report 191 N4 to N6 partqualifications in 2013.

Note 5: "Completion rate" refers to the number of students who successfully completed Report 191 N4 to N6 part-qualifications in the 2013 academic year, expressed as a percentage of the number of students who were eligible to complete Report 191 N4 to N6 part-qualifications and wrote the examinations (the latter is defined above) in 2013.

Note 6: The number of students who registered for, wrote and completed N4 to N6 part-qualifications for Business Studies include the consolidated numbers across both semesters of the 2013 academic year.

Table 41 shows that in private FET Colleges in 2013, almost 21000 students registered for examinations in N4 to N6 part-qualifications for Business Studies. Most students registered for the N4 part-qualification and the lowest number of students registered for the N6 part-qualification. More than 19000 students wrote examinations in N4 to N6 partqualifications; yet only about 4000 completed the part-qualifications. The average completion rate in private FET Colleges for N4 to N6 part-qualifications for Business Studies was $23 \%$. 
Table 42: Number of students in private FET Colleges who registered, wrote and completed the NC(V) Level 4 qualification, by programme and gender, in 2013

\begin{tabular}{|c|c|c|c|c|c|c|c|c|c|}
\hline \multirow[b]{2}{*}{$\mathrm{NC}(\mathrm{V})$ Level 4 Programme } & \multicolumn{3}{|c|}{ Female } & \multicolumn{3}{|c|}{ Male } & \multirow[b]{2}{*}{ 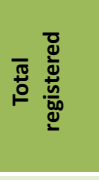 } & \multirow[b]{2}{*}{ 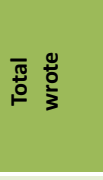 } & \multirow[b]{2}{*}{ ত } \\
\hline & 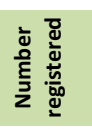 & 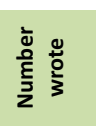 & 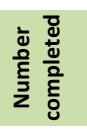 & 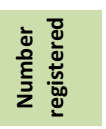 & 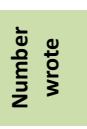 & 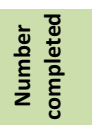 & & & \\
\hline L4:Civil Engineering and Building Construction & 0 & 0 & 0 & 1 & 0 & 0 & 1 & 0 & 0 \\
\hline L4:Education and Development & 4 & 3 & 3 & 0 & 0 & 0 & 4 & 3 & 3 \\
\hline L4:Electrical Infrastructure Construction & 0 & 0 & 0 & 7 & 7 & 0 & 7 & 7 & 0 \\
\hline L4:Engineering and Related Design & 0 & 0 & 0 & 7 & 6 & 0 & 7 & 6 & 0 \\
\hline L4:Finance, Economics and Accounting & 6 & 2 & 0 & 4 & 4 & 0 & 10 & 6 & 0 \\
\hline L4:Hospitality & 3 & 3 & 2 & 0 & 0 & 0 & 3 & 3 & 2 \\
\hline L4:Information Technology and Computer Studies & 19 & 17 & 0 & 49 & 39 & 4 & 68 & 56 & 4 \\
\hline L4:Management & 43 & 37 & 15 & 14 & 12 & 2 & 57 & 49 & 17 \\
\hline L4:Marketing & 36 & 29 & 11 & 36 & 28 & 8 & 72 & 57 & 19 \\
\hline L4:Office Administration & 165 & 147 & 76 & 41 & 37 & 16 & 206 & 184 & 92 \\
\hline L4:Primary Agriculture & 0 & 0 & 0 & 3 & 3 & 0 & 3 & 3 & 0 \\
\hline L4:Safety In Society & 83 & 71 & 45 & 71 & 63 & 37 & 154 & 134 & 82 \\
\hline L4:Tourism & 22 & 19 & 9 & 17 & 13 & 4 & 39 & 32 & 13 \\
\hline Total & 381 & 328 & 161 & 250 & 212 & 71 & 631 & 540 & 232 \\
\hline
\end{tabular}

Source: National Examinations Database, November 2013.

Note 1: The number of students who REGISTERED, WROTE and COMPLETED include only those who were eligible to complete an NC(V) qualification during the 2013 academic year.

Note 2: "Number registered" refers to the number of students who registered for the $2013 \mathrm{NC}(\mathrm{V})$ Level 4 examinations and were eligible to complete an NC(V) qualification during the 2013 academic year. This number excludes students who registered to write individual subjects but who were not eligible to complete the NC(V) Level 4 qualification in 2013.

Note 3: "Number wrote" refers to the number of students who wrote the $2013 \mathrm{NC}(\mathrm{V})$ Level 4 examinations and were eligible to complete an NC(V) qualification during the 2013 academic year. This number excludes students who wrote individual subjects but who were not eligible to complete the NC(V) Level 4 qualification in 2013

Note 4: "Number completed" refers to the number of students who were eligible to complete and successfully completed the NC(V) Level 4 qualification in the 2013 academic year. This number excludes students who may have passed individual subjects but who were not eligible to complete the NC(V) Level 4 qualification in 2013.

Note 5: "Completion rate" refers to the number of students who successfully completed an NC(V) qualification in the 2013 academic year, expressed as a percentage of the number of students who were eligible to complete the $\mathrm{NC}(\mathrm{V})$ Level 4 qualification and wrote the examinations (the latter is defined above) in 2013.

Note 6: $\mathrm{NC}(\mathrm{V})$ Level 4 is a full qualification.

Table 42 shows that in private FET Colleges in 2013, more than 600 students registered for NC(V) Level 4 programmes. More female than male students registered for examinations in the $\mathrm{NC}(\mathrm{V})$ Level 4 qualification. The table also shows that 540 students wrote the examinations for the qualification, but only 232 completed the qualification. Most students registered for the Office Administration programme (206) and only one student registered for the Civil Engineering and Building Construction programme. The majority of female students registered for the Office Administration Programme (165), while most male students enrolled for the Safety in Society programme (71).

Table 42 also shows that none of the students completed the Civil Engineering and Building Construction; Electrical Infrastructure Construction; Engineering and Related Design; Finance, Economic and Accounting; and Primary Agriculture programmes for the NC(V) Level 4 qualification. 
Table 43: Number of students in private FET Colleges who registered, wrote and completed the Report 191 N6 partqualification, by programme and gender, in 2013

\begin{tabular}{|l|}
\hline \\
\hline Report 191 N6 Programmes \\
\hline N6:Art and Design \\
\hline N6:Business Management \\
\hline N6:Clothing Production \\
\hline N6:Educare \\
\hline N6:Engineering Studies \\
\hline N6:Farming Management \\
\hline N6:Financial Management \\
\hline N6:Hospitality and Catering Services \\
\hline N6:Human Resources Management \\
\hline N6:Legal Secretary \\
\hline N6:Management Assistant \\
\hline N6:Marketing Management \\
\hline N6:Medical Secretary \\
\hline N6:Popular Music: Performance \\
\hline N6:Popular Music: Studio Work \\
\hline N6:Public Management \\
\hline N6:Public Relations \\
\hline N6:Tourism \\
\hline Total \\
\hline
\end{tabular}

\begin{tabular}{|c|c|c|c|c|c|c|c|c|}
\hline \multicolumn{3}{|c|}{ Female } & \multicolumn{3}{|c|}{ Male } & \multirow{2}{*}{ 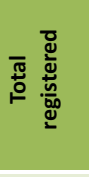 } & \multirow[b]{2}{*}{ 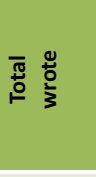 } & \multirow{2}{*}{ 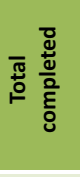 } \\
\hline 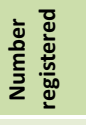 & 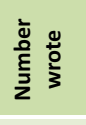 & 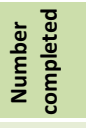 & 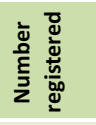 & 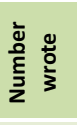 & 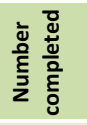 & & & \\
\hline 1 & 1 & 1 & 7 & 5 & 0 & 8 & 6 & 1 \\
\hline 252 & 223 & 46 & 145 & 129 & 23 & 397 & 352 & 69 \\
\hline 7 & 7 & 3 & 0 & 0 & 0 & 7 & 7 & 3 \\
\hline 126 & 123 & 33 & 14 & 14 & 1 & 140 & 137 & 34 \\
\hline 2004 & 1985 & 812 & 4152 & 4094 & 1809 & 6156 & 6079 & 2621 \\
\hline 4 & 4 & 0 & 1 & 0 & 0 & 5 & 4 & 0 \\
\hline 251 & 208 & 25 & 132 & 111 & 28 & 383 & 319 & 53 \\
\hline 21 & 20 & 5 & 8 & 8 & 0 & 29 & 28 & 5 \\
\hline 649 & 583 & 112 & 271 & 237 & 47 & 920 & 820 & 159 \\
\hline 18 & 18 & 3 & 0 & 0 & 0 & 18 & 18 & 3 \\
\hline 277 & 235 & 51 & 40 & 31 & 6 & 317 & 266 & 57 \\
\hline 207 & 202 & 33 & 125 & 118 & 35 & 332 & 320 & 68 \\
\hline 12 & 11 & 3 & 0 & 0 & 0 & 12 & 11 & 3 \\
\hline 0 & 0 & 0 & 1 & 1 & 1 & 1 & 1 & 1 \\
\hline 0 & 0 & 0 & 8 & 6 & 2 & 8 & 6 & 2 \\
\hline 422 & 403 & 123 & 176 & 169 & 66 & 598 & 572 & 189 \\
\hline 192 & 150 & 21 & 59 & 35 & 10 & 251 & 185 & 31 \\
\hline 47 & 45 & 9 & 38 & 35 & 8 & 85 & 80 & 17 \\
\hline 4490 & 4218 & 1280 & 5177 & 4993 & 2036 & 9667 & 9211 & 3316 \\
\hline
\end{tabular}

Source: National Examinations Database, November 2013.

Note 1: The number of students who REGISTERED, WROTE and COMPLETED include only those who were eligible to complete the Report 191 N6 part-qualification during the 2013 academic year.

Note 2: "Number registered" refers to the number of students who registered for the 2013 Report 191 N6 examinations and were eligible to complete a Report 191 N6 partqualification during the 2013 academic year. This number excludes students who registered to write individual subjects but who were not eligible to complete the N6 part-qualification in 2013.

Note 3: "Number wrote" refers to the number of students who wrote the 2013 Report 191 N6 examinations and were eligible to complete a Report 191 N6 partqualification during the 2013 academic year. This number excludes students who wrote individual subjects but who were not eligible to complete the Report $191 \mathrm{~N} 6$ part-qualification in 2013.

Note 4: "Number completed" refers to the number of students who were eligible to complete and successfully completed the Report 191 N6 part-qualification in the 2013 academic year. This number excludes students who may have passed individual subjects but who were not eligible to complete the Report $191 \mathrm{~N} 6$ part-qualification in 2013.

Note 5: "Completion rate" refers to the number of students who successfully completed a Report 191 N6 part-qualification in the 2013 academic year, expressed as a percentage of the number of students who were eligible to complete the Report $191 \mathrm{~N} 6$ part-qualification and wrote the examinations (the latter is defined above) in 2013.

Table 43 shows that in private FET Colleges in 2013, more than 9600 students registered for examinations in the N6 part-qualification. The majority of students $(6$ 156) registered for examinations in the part-qualification for Engineering Studies, while the part-qualification with the lowest number of registered students was Popular Music: Performance, with only one student.

The table also shows that more male than female students registered for the Report $191 \mathrm{~N} 6$ part-qualification. 


\section{ADULT EDUCATION AND TRAINING (AET)}

\subsection{OVERVIEW OF PUBLICAND PRIVATE AET CENTRES}

The provisioning of AET in South Africa is currently underpinned by the Adult Education and Training Act, 2000 (Act No. 52 of 2000). The Act provides for the establishment, governance and funding of AET Centres in South Africa. AET is offered at public and private adult learning Centres for adults and out-of-school youth who seek to complete their schooling and/or who wish to acquire new skills.

The White Paper for Post-School Education and Training provides a new vision for adult education. This vision, which involves the shifting of the function of AET from Provincial Education Departments (PEDs) to the Department of Higher Education and Training (DHET), will begin to take root in April 2015. The AET Act is expected to be repealed and the transitional provisions in Section 25(3)(b) of the Continuing Education and Training Act, 2006 (Act No. 16 of 2006) will become applicable once the AET Act has been repealed.

Figure 12: Number of learners enrolled in public and private AET Centres, from 2011 to 2013

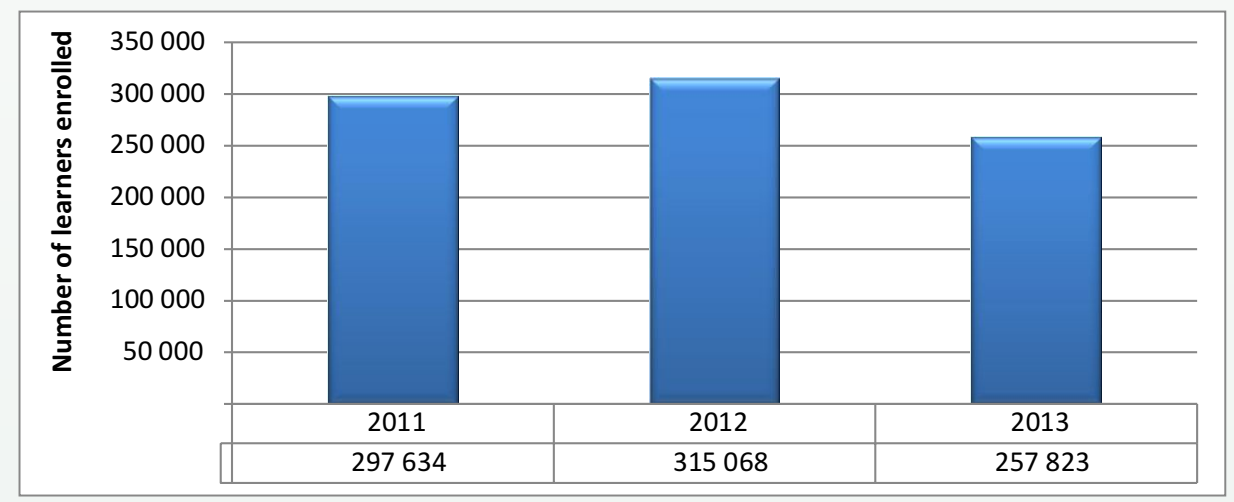

Source: 2013 Annual Survey of AET Centres.

Figure 12 shows that the total learner enrolment in AET Centres (both public and private) decreased from about 298000 in 2011 to approximately 258000 in 2013.

Table 44: Learner enrolment in public and private AET Centres, by institutional type and level, in 2013

\begin{tabular}{|c|c|c|c|c|c|c|c|c|c|}
\hline Type & $\begin{array}{c}\text { ABET } \\
\text { Level } 1\end{array}$ & $\begin{array}{l}\text { ABET } \\
\text { Level } 2\end{array}$ & $\begin{array}{c}\text { ABET } \\
\text { Level } 3\end{array}$ & $\begin{array}{c}\text { ABET } \\
\text { Level 4 } \\
\text { (NQF Level 1) }\end{array}$ & $\begin{array}{c}\text { Grade } 10 \\
\text { (NQF Level 2) }\end{array}$ & $\begin{array}{c}\text { Grade } 11 \\
\text { (NQF Level 3) }\end{array}$ & $\begin{array}{c}\text { Grade } 12 \\
\text { (NQF Level 4) }\end{array}$ & $\begin{array}{l}\text { Other/Skills } \\
\text { Development }\end{array}$ & Total \\
\hline Private AET & 1253 & 1065 & 1289 & 1954 & 89 & 5 & 2053 & 608 & 8316 \\
\hline Total & 16281 & 22631 & 26878 & 111306 & 504 & 762 & 72589 & 6872 & 257823 \\
\hline Percentage & 6.3 & 8.8 & 10.4 & 43.2 & 0.2 & 0.3 & 28.2 & 2.7 & 100 \\
\hline
\end{tabular}

Source: 2013 Annual Survey of AET Centres 20140908.

Table 44 shows that of the approximately 258000 learners enrolled in public and private AET Centres in 2013, a relatively small number (fewer than 8500 ) were enrolled in private AET Centres, suggesting that the private AET sector in the country is very small. More than $43 \%$ of learners in AET Centres (111306) enrolled for the Adult Basic Education and Training (ABET) Level 4 (Level 1 of the National Qualifications Framework [NQF]) qualification in 2013, while more than $28 \%$ of the learners (72 589) enrolled for Grade 12 (NQF Level 4). 


\subsection{PUBLICAET CENTRES}

\subsubsection{Introduction}

Public AET Centres are located mainly in the townships and rural areas of South Africa. The majority of public AET Centres utilise schools for the provision of programmes. Public AET Centres are currently established at provincial level by PEDs. PEDs are responsible for the funding and support of AET Centres, including the recruitment of learners; the appointment of educators and managers; and the establishment of Centres.

In 2013, there were 3150 public AET Centres in South Africa. However, only 1761 public AET Centres responded to the Annual Survey sent to them by the Department.

\subsubsection{Overview of public AET Centres}

Table 45: Number of public AET Centres, educators and learners, by province, in 2013

\begin{tabular}{|c|c|c|c|}
\hline Province & AET Centres & Educators & Learners \\
\hline Eastern Cape & 276 & 2874 & 37935 \\
\hline Free State & 129 & 622 & 14802 \\
\hline Gauteng & 47 & 2369 & 88498 \\
\hline KwaZulu-Natal & 203 & 1149 & 11243 \\
\hline Mpumalanga & 247 & 1848 & 24751 \\
\hline Northern Cape & 120 & 221 & 4333 \\
\hline North West & 263 & 1057 & 19222 \\
\hline Western Cape & 98 & 918 & 30520 \\
\hline National & 1761 & 11922 & 249507 \\
\hline
\end{tabular}

Source: 2013 Annual Survey of AET Centres 20140908.

The statistics reflected in Table 45 are based on the number of public AET Centres that responded to the Department's Annual Survey.

Table 45 shows that there were approximately 250000 learners and 12000 educators in 1800 public AET Centres in 2013. The number of public AET Centres across provinces varied greatly, ranging from 47 in Gauteng to 378 in Limpopo. While Gauteng had the lowest number of public AET Centres in the country, it enrolled the highest number of AET learners in 2013. Gauteng enrolled close to 88500 learners in 2013, followed by the Eastern Cape, which enrolled close to 38000 learners at its 276 public AET Centres. 


\subsubsection{Enrolment in public AET Centres}

Figure 13: Number of learners in public AET Centres, by programme, from 2012 to 2013

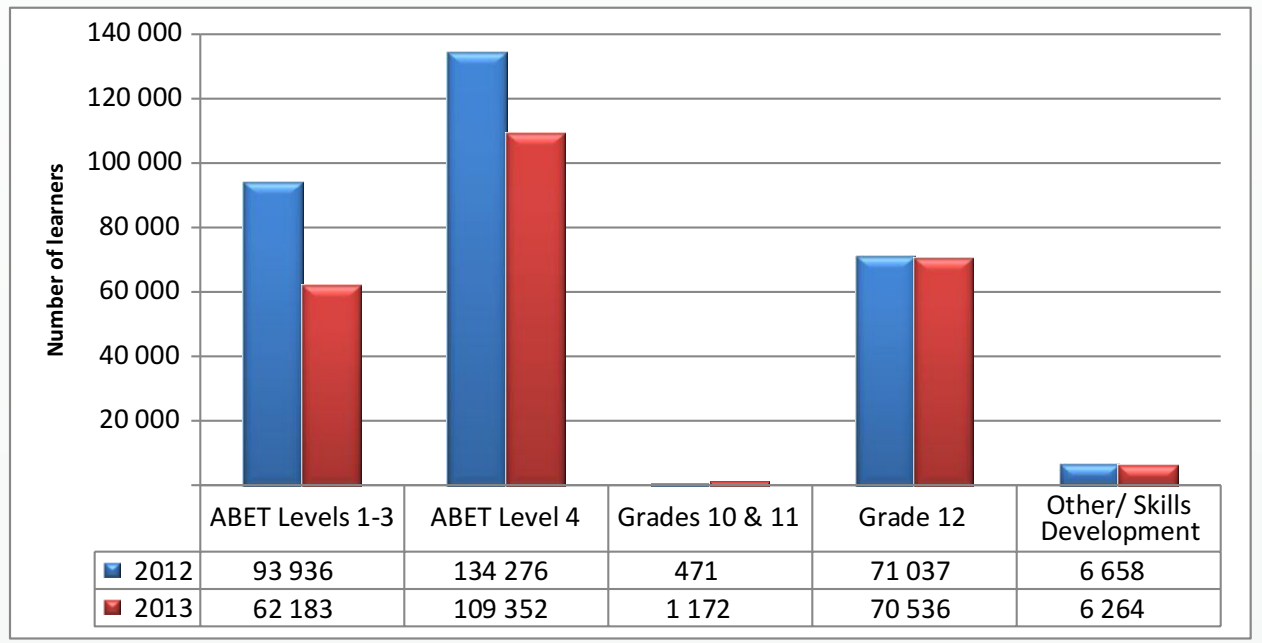

Source: 2013 Annual Survey of AET Centres 20140908.

The statistics reflected in Figure 13 are based on the number of public AET Centres that responded to the Department's Annual Survey.

Figure 13 shows that learner enrolment in four of the five programmes offered at public AET Centres decreased between 2012 and 2013. This decline in learner enrolment was most prominent in ABET programmes.

Table 46: Number of learners in public AET Centres, by province and level, in 2013

\begin{tabular}{|c|c|c|c|c|c|c|c|c|c|}
\hline Province & $\begin{array}{c}\text { ABET } \\
\text { Level } 1\end{array}$ & $\begin{array}{c}\text { ABET } \\
\text { Level } 2\end{array}$ & $\begin{array}{c}\text { ABET } \\
\text { Level } 3\end{array}$ & $\begin{array}{c}\text { ABET } \\
\text { Level } 4 \\
\text { (NQF 1) }\end{array}$ & $\begin{array}{l}\text { Grade } 10 \\
\text { (NQF 2) }\end{array}$ & $\begin{array}{l}\text { Grade } 11 \\
\text { (NQF 3) }\end{array}$ & $\begin{array}{c}\text { Grade } 12 \\
\text { (NQF Level 4) }\end{array}$ & $\begin{array}{l}\text { Other/Skills } \\
\text { Development }\end{array}$ & Total \\
\hline Free State & 326 & 744 & 1753 & 6965 & 54 & 49 & 4797 & 114 & 14802 \\
\hline Gauteng & 2380 & 2289 & 3785 & 23504 & 0 & 584 & 52365 & 3591 & 88498 \\
\hline KwaZulu-Natal & 1246 & 1556 & 2154 & 5587 & 20 & 0 & 655 & 25 & 11243 \\
\hline Limpopo & 499 & 1391 & 1222 & 15015 & 76 & 0 & 0 & 0 & 18203 \\
\hline Mpumalanga & 2182 & 4759 & 4656 & 12777 & 14 & 15 & 283 & 65 & 24751 \\
\hline Northern Cape & 523 & 530 & 567 & 2683 & 0 & 0 & 11 & 19 & 4333 \\
\hline North West & 1970 & 2632 & 3121 & 9807 & 164 & 0 & 883 & 645 & 19222 \\
\hline Western Cape & 2662 & 2069 & 2234 & 10855 & 28 & 93 & 11518 & 1061 & 30520 \\
\hline National & 15028 & 21566 & 25589 & 109352 & 415 & 757 & 70536 & 6264 & 249507 \\
\hline Percentage & 6.0 & 8.6 & 10.3 & 43.8 & 0.2 & 0.3 & 28.3 & 2.5 & 100 \\
\hline
\end{tabular}

Source: 2013 Annual Survey of AET Centres 20140908.

The statistics reflected in Table 46 are based on the number of public AET Centres that responded to the Department's Annual Survey.

Table 46 shows that the majority of learners enrolled for the ABET Level 4 programme were located in Gauteng and the Eastern Cape. Gauteng and the Western Cape had the highest number of learners enrolled for Grade 12 in 2013. 


\subsubsection{Staffing in public AET Centres}

Table 47: Number of staff in public AET Centres, by province, staff category and gender, in 2013

\begin{tabular}{|c|c|c|c|c|c|c|c|c|c|c|c|c|}
\hline \multirow{2}{*}{ Province } & \multicolumn{3}{|c|}{ Management Staff Total } & \multicolumn{3}{|c|}{ Educator Staff Total } & \multicolumn{3}{|c|}{ Support Staff Total } & \multicolumn{3}{|c|}{ Total } \\
\hline & Female & Male & Total & Female & Male & Total & Female & Male & Total & Female & Male & Total \\
\hline Eastern Cape & 205 & 67 & 272 & 2357 & 517 & 2874 & 5 & 0 & 5 & 2567 & 584 & 3151 \\
\hline Free State & 68 & 54 & 122 & 414 & 208 & 622 & 0 & 0 & 0 & 482 & 262 & 744 \\
\hline Gauteng & 14 & 39 & 53 & 1503 & 866 & 2369 & 63 & 64 & 127 & 1580 & 969 & 2549 \\
\hline KwaZulu-Natal & 120 & 37 & 157 & 815 & 334 & 1149 & 1 & 0 & 1 & 936 & 371 & 1307 \\
\hline Limpopo & 343 & 50 & 393 & 713 & 151 & 864 & 1 & 0 & 1 & 1057 & 201 & 1258 \\
\hline Mpumalanga & 198 & 31 & 229 & 1605 & 243 & 1848 & 3 & 0 & 3 & 1806 & 274 & 2080 \\
\hline Northern Cape & 26 & 14 & 40 & 164 & 57 & 221 & 1 & 0 & 1 & 191 & 71 & 262 \\
\hline North West & 157 & 50 & 207 & 845 & 212 & 1057 & 2 & 2 & 4 & 1004 & 264 & 1268 \\
\hline Western Cape & 80 & 60 & 140 & 511 & 407 & 918 & 36 & 25 & 61 & 624 & 492 & 1116 \\
\hline National & 1211 & 402 & 1613 & 8927 & 2995 & 11922 & 112 & 91 & 203 & 10247 & 3488 & 13735 \\
\hline Percentage & 75.1 & 24.9 & 100 & 74.9 & 25.1 & 100 & 55.2 & 44.8 & 100 & 74.6 & 25.4 & 100 \\
\hline
\end{tabular}

Source: 2013 Annual Survey of AET Centres 20140908.

Note 1: "Educator Staff" refers to a person who teaches, educates or trains a learner, or provides professional educational services, including professional therapy and educational psychology services at a Centre.

Note 2: "Management Staff" includes the Centre Manager of an AET Centre.

Note 3: "Support Staff" includes all other staff members who are not teaching. This includes persons who render: academic support services; learner support services; human resource management; financial management; administration; maintenance of buildings and gardens; catering services; and security services.

The statistics reflected in Table 47 are based on the number of public AET Centres that responded to the Department's Annual Survey.

Public AET Centres employed a total of 11922 educators, 1613 management staff and 203 support staff in 2013. More than $74 \%$ of all staff employed at public AET Centres in 2013 were female, with female staff numbers exceeding that of males in all three staff categories. Eastern Cape employed the highest number of staff ( 3151$)$, followed by Gauteng (2549). The Northern Cape employed only 262 staff. 


\subsubsection{Examination results in public AET Centres}

Table 48: Number of learners in public AET Centres who registered, wrote and completed the GETC-ABET Level 4 qualification, from 2011 to 2013

\begin{tabular}{|c|c|c|c|c|}
\hline Year & Number registered & Number wrote & Number completed & Completion rate (\%) \\
\hline 2011 & 107780 & 39856 & 13924 & 34.9 \\
\hline 2012 & 109883 & 55735 & 23325 & 41.8 \\
\hline 2013 & 109518 & 52501 & 19945 & 38.0 \\
\hline
\end{tabular}

Source: National Examinations Database, November 2013.

Note 1: The number of learners who REGISTERED, WROTE and COMPLETED include only those who were eligible to complete a GETC-ABET Level 4 qualification during the 2013 academic year.

Note 2: "Number registered" refers to the number of learners who registered for the 2013 GETC-ABET Level 4 examinations and were eligible to complete a GETC-ABET Level 4 qualification during the 2013 academic year. This number excludes learners who registered to write individual subjects but who were not eligible to complete the GETC-ABET Level 4 qualification in 2013.

Note 3: "Number wrote" refers to the number of learners who wrote the 2013 GETC-ABET Level 4 examinations and were eligible to complete a GETC-ABET qualification during the 2013 academic year. This number excludes learners who wrote individual subjects but who were not eligible to complete the GETC-ABET Level 4 qualification in 2013.

Note 4: "Number completed" refers to the number of learners who were eligible to complete and successfully completed the GETC-ABET Level 4 qualification in the 2013 academic year. This number excludes learners who may have passed individual subjects but who were not eligible to complete the GETC-ABET Level 4 qualification in 2013.

Note 5: "Completion rate" refers to the number of learners who successfully completed a GETC-ABET Level 4 qualification in the 2013 academic year, expressed as a percentage of the number of learners who were eligible to complete the GETC-ABET Level 4 qualification and wrote the examinations (the latter is defined above) in 2013.

Table 48 shows that of the approximately 110000 learners who registered for examinations for the General Education and Training Certificate: Adult Basic Education and Training (GETC-ABET) Level 4 qualification in 2013, only 52500 actually wrote the examinations. However, less than 20000 learners completed the GETC-ABET Level 4 qualification. In contrast to the significant increase in the completion rate from 2011 to 2012, the completion rate for the GETCABET Level 4 examination declined from about $42 \%$ in 2012 to 38\% in 2013. 
Table 49: Number of learners in public AET Centres who registered, wrote and completed the GETC-ABET Level 4 qualification, by province, in 2013

\begin{tabular}{|c|c|c|c|c|}
\hline Province & Number registered & Number wrote & Number completed & Completion rate (\%) \\
\hline Eastern Cape & 14888 & 3735 & 1582 & 42.4 \\
\hline Free State & 7028 & 2844 & 1029 & 36.2 \\
\hline Gauteng & 17090 & 7368 & 2789 & 37.9 \\
\hline KwaZulu-Natal & 21029 & 11219 & 5882 & 52.4 \\
\hline Limpopo & 20993 & 15599 & 5366 & 34.4 \\
\hline Mpumalanga & 13327 & 6068 & 1506 & 24.8 \\
\hline Northern Cape & 2652 & 1343 & 430 & 32.0 \\
\hline North West & 9340 & 3510 & 1131 & 32.2 \\
\hline Western Cape & 3171 & 815 & 230 & 28.2 \\
\hline National & 109518 & 52501 & 19945 & 38.0 \\
\hline
\end{tabular}

Source: National Examinations Database, November 2013.

Note 1: The number of learners who REGISTERED, WROTE and COMPLETED include only those who were eligible to complete a GETC-ABET Level 4 qualification during the 2013 academic year.

Note 2: "Number registered" refers to the number of learners who registered for the 2013 GETC-ABET Level 4 examinations and were eligible to complete a GETC-ABET Level 4 qualification during the 2013 academic year. This number excludes learners who registered to write individual subjects but who were not eligible to complete the GETC-ABET Level 4 qualification in 2013.

Note 3: "Number wrote" refers to the number of learners who wrote the 2013 GETC-ABET Level 4 examinations and were eligible to complete a GETC-ABET Level 4 qualification during the 2013 academic year. This number excludes learners who wrote individual subjects but who were not eligible to complete the GETC-ABET Level 4 qualification in 2013.

Note 4: "Number completed" refers to the number of learners who were eligible to complete and successfully completed the GETC-ABET Level 4 qualification in the 2013 academic year. This number excludes learners who may have passed individual subjects but who were not eligible to complete the GETC-ABET Level 4 qualification in 2013.

Note 5: "Completion rate" refers to the number of learners who successfully completed a GETC-ABET Level 4 qualification in the 2013 academic year, expressed as a percentage of the number of learners who were eligible to complete the GETC-ABET Level 4 qualification and wrote the examinations (the latter is defined above) in 2013.

Table 49 shows that in 2013, the number of learners registered for examinations in the GETC-ABET Level 4 qualification varied greatly across provinces, ranging from 2652 in the Northern Cape to 21029 in KwaZulu-Natal. KwaZulu-Natal was the best-performing province with a completion rate of above 52\% in 2013 (14 percentage points above the national completion rate of 38\%), followed by the Eastern Cape. Mpumalanga performed relatively poorer than other provinces with a completion rate of below $25 \%$. 
Table 50: Number of learners in public AET Centres who registered, wrote and completed the GETC-ABET Level 4 qualification, by province and gender, in 2013

\begin{tabular}{|c|c|c|c|c|c|c|c|c|c|c|c|}
\hline \multirow[b]{2}{*}{ Province } & \multicolumn{4}{|c|}{ Female } & \multicolumn{4}{|c|}{ Male } & \multirow[b]{2}{*}{ 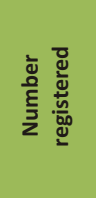 } & \multirow[b]{2}{*}{ 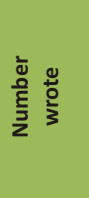 } & \multirow[b]{2}{*}{ 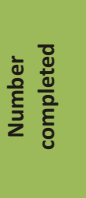 } \\
\hline & 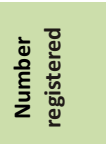 & 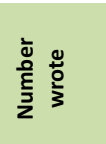 & 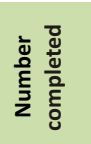 & 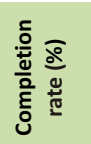 & 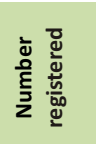 & 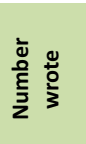 & 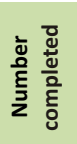 & 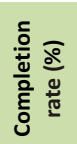 & & & \\
\hline Eastern Cape & 12254 & 3026 & 1303 & 43.1 & 2634 & 709 & 279 & 39.4 & 14888 & 3735 & 1582 \\
\hline Free State & 4907 & 1963 & 754 & 38.4 & 2121 & 881 & 275 & 31.2 & 7028 & 2844 & 1029 \\
\hline Gauteng & 10624 & 4490 & 1896 & 42.2 & 6466 & 2878 & 893 & 31.0 & 17090 & 7368 & 2789 \\
\hline KwaZulu-Natal & 17417 & 9528 & 5029 & 52.8 & 3612 & 1691 & 853 & 50.4 & 21029 & 11219 & 5882 \\
\hline Limpopo & 17691 & 13248 & 4570 & 34.5 & 3302 & 2351 & 796 & 33.9 & 20993 & 15599 & 5366 \\
\hline Mpumalanga & 10893 & 5059 & 1260 & 24.9 & 2434 & 1009 & 246 & 24.4 & 13327 & 6068 & 1506 \\
\hline Northern Cape & 1945 & 1018 & 328 & 32.2 & 707 & 325 & 102 & 31.4 & 2652 & 1343 & 430 \\
\hline North West & 7089 & 2649 & 911 & 34.4 & 2251 & 861 & 220 & 25.6 & 9340 & 3510 & 1131 \\
\hline Western Cape & 1822 & 501 & 133 & 26.5 & 1349 & 314 & 97 & 30.9 & 3171 & 815 & 230 \\
\hline National & 84642 & 41482 & 16184 & 39.0 & 24876 & 11019 & 3761 & 34.1 & 109518 & 52501 & 19945 \\
\hline
\end{tabular}

Source: National Examinations Database, November 2013

Note 1: The number of learners who REGISTERED, WROTE and COMPLETED include only those who were eligible to complete a GETC-ABET Level 4 qualification during the 2013 academic year.

Note 2: "Number registered" refers to the number of learners who registered for the 2013 GETC-ABET Level 4 examinations and were eligible to complete a GETC-ABET Level 4 qualification during the 2013 academic year. This number excludes learners who registered to write individual subjects but who were not eligible to complete the GETC-ABET Level 4 qualification in 2013.

Note 3: "Number wrote" refers to the number of learners who wrote the 2013 GETC-ABET Level 4 examinations and were eligible to complete a GETC-ABET Level 4 qualification during the 2013 academic year. This number excludes learners who wrote individual subjects but who were not eligible to complete the GETC-ABET Level 4 qualification in 2013.

Note 4: "Number completed" refers to the number of learners who were eligible to complete and successfully completed the GETC-ABET Level 4 qualification in the 2013 academic year. This number excludes learners who may have passed individual subjects but who were not eligible to complete the GETC-ABET Level 4 qualification in 2013.

Note 5: "Completion rate" refers to the number of learners who successfully completed a GETC-ABET Level 4 qualification in the 2013 academic year, expressed as a percentage of the number of learners who were eligible to complete the GETC-ABET Level 4 qualification and wrote the examinations (the latter is defined above) in 2013.

Table 50 shows that in 2013, the completion rate for the ABET Level 4 qualification was higher for female learners than males at $39 \%$ and $34 \%$, respectively. 
Table 51: Number of learners in public AET Centres who wrote and passed GETC-ABET Level 4 Learning Areas, by content, in 2013

\begin{tabular}{|l|l|}
\hline Learning Area \\
\hline 1. & Ancillary Health Care \\
\hline 2. & Applied Agriculture and Agricultural Technology \\
\hline 3. & Arts and Culture \\
\hline 4. & Early Childhood Development \\
\hline 5. & Economics and Management Sciences \\
\hline 6. & Human and Social Sciences \\
\hline 7. & Inform. and Communication Technology \\
\hline 8. & Life Orientation \\
\hline 9. & Mathematical Literacy \\
\hline 10. & Mathematics and Mathematical Sciences \\
\hline 11. & Natural Sciences \\
\hline 12. & Small Medium and Micro Enterprises \\
\hline 13. & Technology \\
\hline 14. & Travel and Tourism \\
\hline 15. & Wholesale and Retail \\
\hline
\end{tabular}

\begin{tabular}{|c|c|c|}
\hline Number wrote & Number passed & Pass rate (\%) \\
\hline 55280 & 34470 & 62.4 \\
\hline 9331 & 4895 & 52.5 \\
\hline 11077 & 9453 & 85.3 \\
\hline 12663 & 11759 & 92.9 \\
\hline 26848 & 19940 & 74.3 \\
\hline 17603 & 15251 & 86.6 \\
\hline 1887 & 1539 & 81.6 \\
\hline 72765 & 54327 & 74.7 \\
\hline 78754 & 50407 & 64.0 \\
\hline 5564 & 2101 & 37.8 \\
\hline 15375 & 7381 & 48.0 \\
\hline 15241 & 9509 & 62.4 \\
\hline 3166 & 1764 & 55.7 \\
\hline 25502 & 17224 & 67.5 \\
\hline 1872 & 880 & 47.0 \\
\hline
\end{tabular}

Source: National Examinations Database, November 2013.

Note 1: The number of learners who WROTE and PASSED included learners who wrote and passed a Learning Area, irrespective of whether or not they were eligible to complete the GETC-ABET Level 4 qualification during the 2013 academic year.

Note 2: "Number wrote" refers to the number of learners who wrote a Learning Area, irrespective of whether or not they were eligible to complete the GETC-ABET Level 4 qualification during the 2013 academic year.

Note 3: "Number passed" refers to the number of learners who passed a Learning Area, irrespective of whether or not they were eligible to complete the GETC-ABET Level 4qualification during the 2013 academic year.

Note 4: "Pass rate" refers to the number of learners who successfully passed a Learning Area in the GETC-ABET Level 4 qualification, expressed as a percentage of the number of candidates who wrote a Learning Area, irrespective of whether or not they were eligible to complete the GETC-ABET Level 4 qualification (the latter is defined above) in 2013.

Table 51 shows that in 2013, the pass rate was highest for the Early Childhood Development Learning Area (at 93\%), followed by Human and Social Sciences (at $87 \%$ ). The lowest pass rate was in the Mathematics and Mathematical Sciences Learning Area at 38\%. 
Table 52: Number of learners in public AET Centres who wrote and passed GETC-ABET Level 4 Learning Areas, by language, in 2013

\begin{tabular}{|l|l|}
\hline \multicolumn{2}{|l|}{ Language Learning Area } \\
\hline 1. & Afrikaans \\
\hline 2. & English \\
\hline 3. & SeSotho \\
\hline 4. & IsiZulu \\
\hline 5. & IsiXhosa \\
\hline 6. & SiSwati \\
\hline 7. & SePedi \\
\hline 8. & TshiVenda \\
\hline 9. & XiTsonga \\
\hline 10. & SeTswana \\
\hline 11. & IsiNdebele \\
\hline
\end{tabular}

\begin{tabular}{|r|}
\hline Number wrote \\
\hline 1644 \\
\hline 80629 \\
\hline 1109 \\
\hline 7961 \\
\hline 5441 \\
\hline 2158 \\
\hline 9091 \\
\hline 2202 \\
\hline 2819 \\
\hline 3960 \\
\hline 456 \\
\hline
\end{tabular}

\begin{tabular}{|r|r|}
\hline Number passed & \\
\hline 1313 \\
53219 \\
937 \\
\hline 7237 \\
\hline 5170 \\
\hline 2010 \\
8329 \\
\hline 2135 \\
\hline 2634 \\
3312 \\
375 \\
\hline
\end{tabular}

\begin{tabular}{|c|}
\hline Pass rate (\%) \\
\hline \\
\hline
\end{tabular}

Source: National Examinations Database, November 2013

Note 1: The number of learners who WROTE and PASSED include learners who wrote and passed a Language Learning Area, irrespective of whether or not they were eligible to complete the GETC-ABET Level 4 qualification during the 2013 academic year.

Note 2: "Number wrote" refers to the number of learners who wrote a Learning Area, irrespective of whether or not they were eligible to complete the GETC-ABET Level 4 qualification during the 2013 academic year.

Note 3: "Number passed" refers to the number of learners who passed a Learning Area, irrespective of whether or not they were eligible to complete the GETC-ABET Level 4 qualification during the 2013 academic year.

Note 4: "Pass rate" refers to the number of learners who successfully passed a Learning Area in the GETC-ABET Level 4 qualification, expressed as a percentage of the number of candidates who wrote a Learning Area irrespective of whether or not they were eligible to complete the GETC-ABET Level 4 qualification (the latter is defined above) in 2013.

Table 52 shows that the pass rates for the Language Learning Areas were generally fairly high, ranging from $66 \%$ to 97\%. Of the 80600 learners who wrote English for the GETC-ABET Level 4 qualification in $2013,66 \%$ passed. The highest pass rate was among learners who wrote TshiVenda at $97 \%$, while the lowest was for English at $66 \%$. The lowest number of learners wrote the IsiNdebele examination ( 456 learners with a pass rate of $82 \%$ ). 


\subsection{PRIVATE AET CENTRES}

\subsubsection{Introduction}

By law, private AET Centres are required to be registered with the DHET, as provided in terms of Section 27 of the Adult Education and Training Act, 2000 (Act No. 52 of 2000). A private AET Centre could be defined as an institution or organisation that has the following characteristics:

- It is independent from the state;

- It is wholly or partly owned and funded by an individual/s;

- It is regulated by an act of parliament;

- It determines its own governance and management arrangements; and

- It may be a profit or non-profit making organisation.

Qualifications offered by private AET Centres must be accredited by the relevant quality council, namely Umalusi.

Only 62 private AET Centres responded to the Annual Survey sent to them by the DHET. Therefore, the data provided below must be read in this context.

\subsubsection{Overview of private AET Centres}

Table 53: Number of private AET Centres, educators and learners, by province, in 2013

\begin{tabular}{|c|c|c|c|}
\hline Province & AET Centres & Educators & Learners \\
\hline Eastern Cape & 0 & 0 & 0 \\
\hline Free State & 3 & 7 & 235 \\
\hline Gauteng & 9 & 74 & 2808 \\
\hline KwaZulu-Natal & 10 & 15 & 529 \\
\hline Limpopo & 1 & 4 & 64 \\
\hline Mpumalanga & 4 & 13 & 254 \\
\hline Northern Cape & 3 & 1 & 211 \\
\hline North West & 11 & 52 & 1140 \\
\hline Western Cape & 21 & 76 & 3075 \\
\hline National & 62 & 242 & 8316 \\
\hline
\end{tabular}

Source: 2013 Annual Survey of AET Centres 20140908.

As can be seen in Table 53, there were 62 private AET Centres that responded to the departmental Annual Survey in 2013. Most of these Centres (21) were located in the Western Cape. Although Gauteng had a limited number of private AET Centres, it had a relatively high number of learners enrolled in private AET Centres.

Table 53 shows that more than 8300 learners enrolled in private AET Centres in 2013. The number of AET Centres across provinces varied greatly, ranging from zero in the Eastern Cape to 21 in the Western Cape. Similarly, learner enrolment in private AET Centres varied significantly across provinces, with the Western Cape having more than 3000 learners compared with Limpopo with 64 learners. 


\subsubsection{Enrolment in private AET Centres}

Figure 14: Number of learners in private AET Centres, by programme, from 2012 to 2013

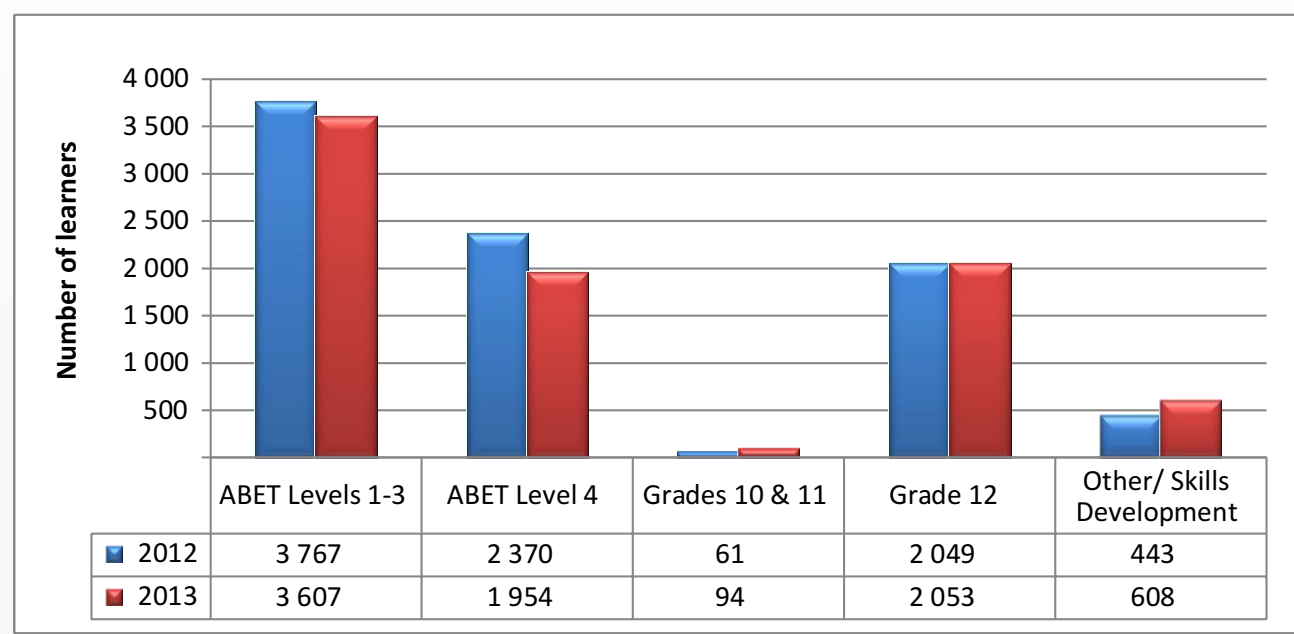

Source: 2013 Annual Survey of AET Centres 20140908.

Figure 14 shows that the majority of learners in private AET Centres enrolled for ABET Levels 1 to 4 programmes in 2013, followed by those enrolled for Grade 12. The number of learners enrolled for ABET programmes in private AET Centres (all levels) decreased between 2012 and 2013, while that for Grade 12 and "Other/Skills Development" programmes increased slightly.

Table 54: Number of learners enrolled in private AET Centres, by province and level, in 2013

\begin{tabular}{|c|c|c|c|c|c|c|c|c|c|}
\hline Province & $\begin{array}{c}\text { ABET } \\
\text { Level } 1\end{array}$ & $\begin{array}{c}\text { ABET } \\
\text { Level } 2\end{array}$ & $\begin{array}{c}\text { ABET } \\
\text { Level } 3\end{array}$ & $\begin{array}{c}\text { ABET } \\
\text { Level } 4 \\
\text { (NQF 1) }\end{array}$ & $\begin{array}{l}\text { Grade } 10 \\
\text { (NQF 2) }\end{array}$ & $\begin{array}{l}\text { Grade } 11 \\
\text { (NQF 3) }\end{array}$ & $\begin{array}{c}\text { Grade } 12 \\
\text { (NQF Level 4) }\end{array}$ & $\begin{array}{l}\text { Other/Skills } \\
\text { Development }\end{array}$ & Total \\
\hline Free State & 13 & 9 & 16 & 154 & 0 & 0 & 43 & 0 & 235 \\
\hline Gauteng & 292 & 324 & 371 & 431 & 41 & 5 & 1069 & 275 & 2808 \\
\hline KwaZulu-Natal & 63 & 61 & 60 & 240 & 0 & 0 & 105 & 0 & 529 \\
\hline Limpopo & 0 & 4 & 4 & 56 & 0 & 0 & 0 & 0 & 64 \\
\hline Mpumalanga & 22 & 17 & 26 & 43 & 0 & 0 & 48 & 98 & 254 \\
\hline Northern Cape & 19 & 40 & 45 & 71 & 36 & 0 & 0 & 0 & 211 \\
\hline North West & 159 & 108 & 88 & 344 & 0 & 0 & 340 & 101 & 1140 \\
\hline National & 1253 & 1065 & 1289 & 1954 & 89 & 5 & 2053 & 608 & 8316 \\
\hline Percentage & 15.1 & 12.8 & 15.5 & 23.5 & 1.1 & 0.1 & 24.7 & 7.3 & 10 \\
\hline
\end{tabular}

Source: 2013 Annual Survey of AET Centres 20140908.

Table 54 shows that in 2013, almost $25 \%$ of learners in private AET Centres were enrolled for Grade 12 , followed by ABET Level 4 at $24 \%$. The enrolment of learners in private AET Centres across provinces varied greatly, ranging from 64 in Limpopo to 3075 in the Western Cape. The majority of learners in private AET Centres were located in the Western Cape, Gauteng and North West, respectively. 


\subsubsection{Staffing in private AET Centres}

Table 55: Number of staff in private AET Centres, by province, staff category and gender, in 2013

\begin{tabular}{|c|c|c|c|c|c|c|c|c|c|c|c|c|}
\hline \multirow{2}{*}{ Province } & \multicolumn{3}{|c|}{ Management Staff Total } & \multicolumn{3}{|c|}{ Educator Staff Total } & \multicolumn{3}{|c|}{ Support Staff Total } & \multicolumn{3}{|c|}{ Total } \\
\hline & Female & Male & Total & Female & Male & Total & Female & Male & Total & Female & Male & Total \\
\hline Eastern Cape & 0 & 0 & 0 & 0 & 0 & 0 & 36 & 5 & 41 & 36 & 5 & 41 \\
\hline Free State & 2 & 1 & 3 & 5 & 2 & 7 & 15 & 3 & 18 & 22 & 6 & 28 \\
\hline Gauteng & 4 & 10 & 14 & 34 & 40 & 74 & 131 & 125 & 256 & 169 & 175 & 344 \\
\hline KwaZulu-Natal & 8 & 0 & 8 & 9 & 6 & 15 & 34 & 9 & 43 & 51 & 15 & 66 \\
\hline Limpopo & 2 & 0 & 2 & 4 & 0 & 4 & 7 & 0 & 7 & 13 & 0 & 13 \\
\hline Mpumalanga & 0 & 3 & 3 & 5 & 8 & 13 & 7 & 3 & 10 & 12 & 14 & 26 \\
\hline Northern Cape & 1 & 1 & 4 & 0 & 1 & 1 & 3 & 1 & 4 & 4 & 3 & 7 \\
\hline North West & 3 & 1 & 2 & 40 & 12 & 52 & 9 & 9 & 18 & 52 & 22 & 74 \\
\hline Western Cape & 9 & 15 & 24 & 47 & 29 & 76 & 73 & 70 & 143 & 129 & 114 & 243 \\
\hline National & 29 & 31 & 60 & 144 & 98 & 242 & 315 & 225 & 540 & 488 & 354 & 842 \\
\hline Percentage & 48.3 & 51.7 & 100 & 59.5 & 40.5 & 100 & 58.3 & 41.7 & 100 & 58 & 42 & 100 \\
\hline
\end{tabular}

Source: 2013 Annual Survey of AET Centres 20140908.

Note 1: The category "Management Staff" includes the Centre Manager of a Centre.

Note 2: The category "Educator Staff" refers to a person who teaches, educates or trains a learner, or provides professional educational services, including professional therapy and educational psychology services, at a Centre.

Note 3: The category "Support Staff" refers to all other staff members who are not teaching. This includes persons who render: academic support services; learner support services; human resource management; financial management; administration; maintenance of buildings and gardens; catering services; and security services.

In 2013, private AET Centres employed a total of 842 staff of which $58 \%$ were female. The majority of staff in private AET Centres were employed as support staff (540), while 242 persons were employed as educator staff and 60 as management staff. Support staff and educator staff comprised mainly females, while males dominated the management staff category. 


\section{SECTOR EDUCATION AND TRAINING AUTHORITY (SETA)-SUPPORTED LEARNING PROGRAMMES}

\section{$6.1 \quad$ INTRODUCTION}

SETAs were established in terms of the Skills Development Act, 1998 (Act No. 97 of 1998) to facilitate and promote skills development in response to the needs of the economy. Currently, there are 21 SETAs in South Africa classified according to economic sectors. The functions and responsibilities of SETAs are set out in Chapter 3, Section 10 of the Skills Development Act, 1998 (Act No. 97 of 1998) (as amended) which, inter alia, states that SETAs are to:

- Develop sector skills plans within the framework of the National Skills Development Strategy (NSDS);

- Implement their sector skills plans by: (a) establishing learning programmes, (b) approving workplace skills plans and annual training reports, (c) allocating grants in the prescribed manner and (d) monitoring education and skills development provision in their sectors;

- Promote learning programmes by: (a) identifying workplaces for practical work experience, (b) supporting the development of learning materials, (c) improving the facilitation of learning and (d) assisting in the conclusion of agreements for learning programmes to the extent that it is required;

- $\quad$ Register agreements for learning programmes to the extent that it is required;

- Perform any functions delegated to them by the Quality Council for Trades and Occupations (QCTO) in terms of Section 26 l of the Skills Development Act, 1998 (Act No.97 of 1998); and

- When required to do so as contemplated in Section 7(1) of the Skills Development Levies Act, 1999 (Act No. 9 of 1999) collect skills development levies and disburse the levies allocated to them in terms of Sections 8(3)(b) and 9(b) of the Skills Development Levies Act, 1999 (Act No. 9 of 1999) in their respective sectors.

The Department of Higher Education and training (DHET) is responsible for the management of SETA performance to ensure that the above functions are undertaken effectively and efficiently. The Department is determined to realise the slogan of "together turning every workplace into a training space" by ensuring that significant numbers of young people are able to access workplace-based training through learnerships, apprenticeships and internships.

This section of the report provides information on the number of workers and unemployed persons who are registered in SETA-supported learning programmes, namely learnerships, internships and skills programmes. It includes a special sub-section on apprenticeships and artisans owing to the importance government attaches to the development of greater numbers of artisans in the country. 


\section{2}

REGISTRATION AND CERTIFICATION OF SETA-SUPPORTED LEARNING PROGRAMMES: TREND DATA

Table 56: Number of workers and unemployed persons registered for and certificated in SETA-supported learning programmes, by programme type, from $2011 / 12$ to $2013 / 14$
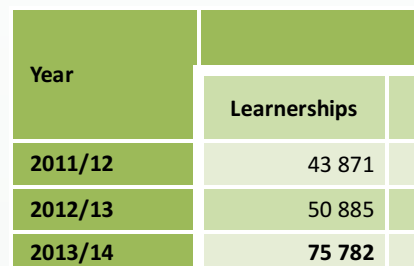

\begin{tabular}{|l|}
\hline Register \\
\hline 452 \\
6127 \\
8017
\end{tabular}

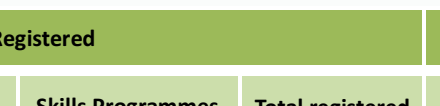

\begin{tabular}{|c|c|c|c|}
\hline \multicolumn{4}{|c|}{ Certificated } \\
\hline Learnerships & Internships & Skills Programmes & Total certificated \\
\hline 29197 & 878 & 87527 & 117602 \\
\hline 37158 & 2195 & 86491 & 125844 \\
\hline 38796 & 2510 & 109547 & 150853 \\
\hline
\end{tabular}

Source: SETA Quarterly Reports, 2013/14.

Note 1: The category "Learnerships" refers to a learning programme that leads to an occupational qualification or part-qualification and includes an apprenticeship and cadetship.

Note 2: The category "Internships" refers to the structured work experience component of an occupational qualification registered by the QCTO.

Note 3: The category "Skills Programmes" refers to a part-qualification as defined in the National Qualifications Framework (NQF) Act, 2008 (Act No. 67 of 2008).

Table 56 shows that more than 176000 persons (both workers and unemployed persons) registered for SETAsupported learning programmes in the 2013/14 financial year, reflecting a significant increase since $2011 / 12$. More than half of all persons involved in SETA-supported learning programmes registered for skills programmes, while 75782 learners registered for learnerships in 2013/14. Although the number of persons registered for internships in 2013/14 were relatively smaller ( 8017 ) in relation to other learning programmes, a significant increase in the number of internships is evident between 2011/12 and 2012/13.

The number of persons who were certificated in SETA-supported learning programmes increased from 117602 in $2011 / 12$ to 150853 in 2013/14. By far the majority were certificated in skills programmes. 


\subsubsection{Workers registered for SETA-supported learning programmes}

Table 57: Number of workers registered for SETA-supported learning programmes, by programme type and SETA, in 2013/14

\begin{tabular}{|c|c|c|c|c|c|c|c|c|}
\hline \multirow{2}{*}{ SETA } & \multicolumn{3}{|c|}{ Learnerships } & \multicolumn{3}{|c|}{ Skills Programmes } & \multirow{2}{*}{$\begin{array}{c}\text { Total } \\
\text { target }\end{array}$} & \multirow{2}{*}{$\begin{array}{l}\text { Total } \\
\text { actual }\end{array}$} \\
\hline & Target & Actual & Achieved (\%) & Target & Actual & Achieved (\%) & & \\
\hline AGRISETA & 1000 & 1809 & 181 & 1000 & 3183 & 318 & 2000 & 4992 \\
\hline BANKSETA & 1300 & 2311 & 178 & 1040 & 1757 & 169 & 2340 & 4068 \\
\hline CATHSSETA & 1500 & 1572 & 105 & 1250 & 2097 & 168 & 2750 & 3669 \\
\hline CETA & 2000 & 499 & 25 & 4000 & 1077 & 27 & 6000 & 1576 \\
\hline CHIETA & 1500 & 2083 & 139 & 3000 & 2587 & 86 & 4500 & 4670 \\
\hline ETDP SETA & 450 & 459 & 102 & 4780 & 5025 & 105 & 5230 & 5484 \\
\hline EWSETA & 2000 & 119 & 6 & 4000 & 1122 & 28 & 6000 & 1241 \\
\hline FASSET & 950 & 819 & 86 & 23500 & 10631 & 45 & 24450 & 11450 \\
\hline FOODBEV & 1000 & 1000 & 100 & 500 & 580 & 116 & 1500 & 1580 \\
\hline FP\&M SETA & 1000 & 684 & 68 & 1600 & 2162 & 135 & 2600 & 2846 \\
\hline HWSETA & 2000 & 2548 & 127 & 4125 & 7322 & 178 & 6125 & 9870 \\
\hline INSETA & 1000 & 1315 & 132 & 3000 & 2893 & 96 & 4000 & 4208 \\
\hline LGSETA & 3000 & 1031 & 34 & 4750 & 845 & 18 & 7750 & 1876 \\
\hline MERSETA & 4500 & 2443 & 54 & 3400 & 3914 & 115 & 7900 & 6357 \\
\hline MICT SETA & 51 & 64 & 125 & 3000 & 3003 & 100 & 3051 & 3067 \\
\hline MQA & 1500 & 1954 & 130 & 10000 & 13274 & 133 & 11500 & 15228 \\
\hline PSETA & 0 & 164 & - & 675 & 705 & 104 & 675 & 869 \\
\hline SASSETA & 250 & 1764 & 706 & 1080 & 2929 & 271 & 1330 & 4693 \\
\hline SERVICES & 5050 & 3123 & 62 & 4000 & 895 & 22 & 9050 & 4018 \\
\hline TETA & 1500 & 470 & 31 & 4000 & 1669 & 42 & 5500 & 2139 \\
\hline W\&RSETA & 2400 & 3383 & 141 & 700 & 6437 & 920 & 3100 & 9820 \\
\hline Total & 33951 & 29614 & 88 & 83400 & 74107 & 89 & 117351 & 103721 \\
\hline
\end{tabular}

Source: SETA Quarterly Reports, 2013/14.

Note 1: The category "Learnerships" refers to a learning programme that leads to an occupational qualification or part-qualification and includes an apprenticeship and cadetship.

Note 2: The category "Internships" refers to the structured work experience component of an occupational qualification registered by the QCTO.

Note 3: The category "Skills Programmes" refers to a part-qualification as defined in the NQFAct, 2008 (Act No. 67 of 2008).

Note 4: Dash (-) means that data is not available.

Table 57 shows that a total of 103721 workers registered for learnerships and skills programmes in 2013/14, the majority of whom registered for skills programmes. While many SETAs exceeded their registration targets significantly for this period, overall, SETAs underachieved on their set targets by $12 \%$. 


\subsubsection{Workers certificated in SETA-supported learning programmes}

Table 58: Number of workers certificated in SETA-supported learning programmes, by programme type, in 2013/14

\begin{tabular}{|c|c|c|c|c|c|c|c|c|}
\hline \multirow{2}{*}{ SETA } & \multicolumn{3}{|c|}{ Learnerships } & \multicolumn{3}{|c|}{ Skills Programmes } & \multirow{2}{*}{$\begin{array}{c}\text { Total } \\
\text { target }\end{array}$} & \multirow{2}{*}{$\begin{array}{c}\text { Total } \\
\text { actual }\end{array}$} \\
\hline & Target & Actual & Achieved (\%) & Target & Actual & Achieved (\%) & & \\
\hline AGRISETA & 500 & 796 & 159 & 500 & 3022 & 604 & 1000 & 3818 \\
\hline BANKSETA & 844 & 729 & 86 & 180 & 619 & 344 & 1024 & 1348 \\
\hline CATHSSETA & 750 & 289 & 39 & 625 & 4719 & 755 & 1375 & 5008 \\
\hline CETA & 2000 & 442 & 22 & 4000 & 567 & 14 & 6000 & 1009 \\
\hline CHIETA & 750 & 1187 & 158 & 1500 & 2799 & 187 & 2250 & 3986 \\
\hline ETDP SETA & - & - & - & 3346 & 2160 & 65 & 3346 & 2160 \\
\hline EWSETA & 2000 & 224 & 11 & 4000 & 2276 & 57 & 6000 & 2500 \\
\hline FASSET & 317 & 453 & 143 & 23500 & 17030 & 72 & 23817 & 17483 \\
\hline FOODBEV & 500 & 426 & 85 & 250 & 999 & 400 & 750 & 1425 \\
\hline FP\&M SETA & 500 & 531 & 106 & 800 & 1299 & 162 & 1300 & 1760 \\
\hline HWSETA & 1600 & 1664 & 104 & 3300 & 6124 & 186 & 4900 & 7788 \\
\hline INSETA & 700 & 106 & 15 & 2100 & 2618 & 125 & 2800 & 2724 \\
\hline LGSETA & 1000 & 482 & 48 & 2950 & 360 & 12 & 3950 & 842 \\
\hline MERSETA & 2200 & 2454 & 112 & 2380 & 1293 & 54 & 4580 & 3747 \\
\hline MICT SETA & 35 & 45 & 129 & 2000 & 3003 & 150 & 2035 & 3048 \\
\hline MQA & 1500 & 1676 & 112 & 7000 & 37637 & 538 & 8500 & 39313 \\
\hline PSETA & - & 42 & - & 550 & 575 & 105 & 550 & 617 \\
\hline SASSETA & 200 & 271 & 136 & 864 & 552 & 64 & 1064 & 823 \\
\hline SERVICES & 5050 & 352 & 7 & 4000 & 0 & 0 & 9050 & 352 \\
\hline TETA & 250 & 203 & 81 & 800 & 529 & 66 & 1050 & 732 \\
\hline W\&RSETA & 1852 & 2551 & 138 & 998 & 2513 & 252 & 2850 & 5064 \\
\hline Total & 22548 & 14923 & 66 & 65643 & 90694 & 138 & 88191 & 105617 \\
\hline
\end{tabular}

Source: SETA Quarterly Reports, 2013/14.

Note 1: The category "Learnerships" refers to a learning programme that leads to an occupational qualification or part-qualification and includes an apprenticeship and cadetship.

Note 2: The category "Internships" refers to the structured work experience component of an occupational qualification registered by the QCTO.

Note 3: The category "Skills Programmes" refers to a part-qualification as defined in the NQFAct, 2008 (Act No. 67 of 2008).

Note 4: Dash (-) means that data is not available.

Table 58 above indicates that more than 105000 workers were certificated in learnerships and skills programmes in 2013/14, with the majority (90 694) certificated in skills programmes. Skills programmes over-achieved their set target by more than $38 \%$, while the target for learnerships was underachieved by $34 \%$. 


\subsubsection{Unemployed persons registered for SETA-supported learning programmes}

Table 59: Number of unemployed persons registered for SETA-supported learning programmes, by programme type, in 2013/14

\begin{tabular}{|c|c|c|c|c|c|c|c|c|c|c|c|}
\hline \multirow{2}{*}{ SETA } & \multicolumn{3}{|c|}{ Learnerships } & \multicolumn{3}{|c|}{ Internships } & \multicolumn{3}{|c|}{ Skills Programmes } & \multirow{2}{*}{$\begin{array}{c}\text { Total } \\
\text { target }\end{array}$} & \multirow{2}{*}{$\begin{array}{l}\text { Total } \\
\text { actual }\end{array}$} \\
\hline & Target & Actual & Achieved (\%) & Target & Actual & Achieved (\%) & Target & Actual & Achieved (\%) & & \\
\hline AGRISETA & 115 & 1834 & 1595 & 400 & 696 & 174 & 5780 & 3398 & 59 & 6295 & 5928 \\
\hline BANKSETA & 755 & 2162 & 286 & 100 & 141 & 141 & 210 & 401 & 191 & 1065 & 2704 \\
\hline CATHSSETA & 500 & 1262 & 252 & 100 & 147 & 147 & 960 & 336 & 35 & 1560 & 1745 \\
\hline CETA & 6000 & 4528 & 75 & 1450 & 160 & 11 & 1000 & 867 & 87 & 8450 & 5555 \\
\hline CHIETA & 2000 & 2040 & 102 & 100 & 185 & 185 & 1000 & 1015 & 102 & 3100 & 3240 \\
\hline ETDP SETA & 1500 & 1473 & 98 & 540 & 636 & 118 & 500 & 402 & 80 & 2540 & 2511 \\
\hline EWSETA & 3000 & 2993 & 100 & 620 & 1040 & 168 & 1000 & 200 & 20 & 4620 & 4233 \\
\hline FASSET & 5200 & 3820 & 73 & 100 & 48 & 48 & 1250 & 0 & 0 & 6550 & 3868 \\
\hline FOODBEV & 800 & 800 & 100 & 150 & 423 & 282 & 0 & 0 & 0 & 950 & 1223 \\
\hline FP\&M SETA & 1500 & 2192 & 146 & 333 & 332 & 100 & 900 & 794 & 88 & 2733 & 3318 \\
\hline HWSETA & 3450 & 1983 & 57 & 100 & 291 & 291 & 1000 & 1605 & 161 & 4550 & 3879 \\
\hline INSETA & 2000 & 1342 & 67 & 1850 & 643 & 35 & 1000 & 1405 & 141 & 4850 & 3390 \\
\hline LGSETA & 2630 & 1958 & 74 & 100 & 121 & 121 & 3200 & 553 & 17 & 5930 & 2632 \\
\hline MERSETA & 4500 & 3151 & 70 & 221 & 346 & 157 & 1500 & 3259 & 217 & 6221 & 6756 \\
\hline MICT SETA & 2500 & 2580 & 103 & 400 & 568 & 142 & 1337 & 1428 & 107 & 4237 & 4576 \\
\hline MQA & 1500 & 1154 & 77 & 900 & 367 & 41 & 2000 & 1285 & 64 & 4400 & 2806 \\
\hline PSETA & 700 & 187 & 27 & 213 & 919 & 431 & 0 & 0 & 0 & 913 & 1106 \\
\hline SASSETA & 1200 & 2271 & 189 & 300 & 177 & 59 & 1500 & 195 & 13 & 3000 & 2643 \\
\hline SERVICES & 6500 & 2891 & 44 & 2795 & 408 & 15 & 2000 & 30 & 2 & 11295 & 3329 \\
\hline TETA & 2500 & 1475 & 59 & 1000 & 107 & 11 & 1000 & 573 & 57 & 4500 & 2155 \\
\hline W\&RSETA & 2400 & 3646 & 152 & 300 & 256 & 85 & 400 & 617 & 154 & 3100 & 4519 \\
\hline Total & 51250 & 45742 & 89 & 12072 & 8011 & 66 & 27537 & 18363 & 67 & 90859 & 72116 \\
\hline
\end{tabular}

Source: SETA Quarterly Reports, 2013/14.

Note 1: The category "Learnerships" refers to a learning programme that leads to an occupational qualification or part-qualification and includes an apprenticeship and cadetship.

Note 2: The category "Internships" refers to the structured work experience component of an occupational qualification registered by the QCTO.

Note 3: The category "Skills Programmes" refers to a part-qualification as defined in the NQFAct, 2008 (Act No. 67 of 2008).

Table 59 shows that, in 2013/14, a total of 72116 unemployed persons were registered in SETA-supported learning programmes. More than half of all unemployed persons involved in SETA-supported learning programmes were registered for learnerships, while 18363 learners were registered for skills programmes in 2013/14. A relatively small number of unemployed persons (8011) were registered for internships through the SETA contractual system.

The SETAs did not meet their set targets in all three learning programmes (learnerships, internships and skills programmes) in 2013/14. 


\subsubsection{Unemployed persons certificated in SETA-supported learning programmes}

Table 60: Number of unemployed persons certificated in SETA-supported learning programmes, by programme type, in 2013/14

\begin{tabular}{|c|c|c|c|c|c|c|c|c|c|c|c|}
\hline \multirow{2}{*}{ SETA } & \multicolumn{3}{|c|}{ Learnerships } & \multicolumn{3}{|c|}{ Internships } & \multicolumn{3}{|c|}{ Skills Programmes } & \multirow{2}{*}{$\begin{array}{l}\text { Total } \\
\text { target }\end{array}$} & \multirow{2}{*}{$\begin{array}{l}\text { Total } \\
\text { actual }\end{array}$} \\
\hline & Target & Actual & Achieved (\%) & Target & Actual & Achieved (\%) & Target & Actual & Achieved (\%) & & \\
\hline AGRISETA & 563 & 996 & 177 & 200 & 379 & 190 & 2890 & 2970 & 103 & 3653 & 4345 \\
\hline BANKSETA & 348 & 917 & 264 & 48 & 122 & 254 & 168 & 341 & 203 & 564 & 1380 \\
\hline CATHSSETA & 250 & 798 & 319 & 80 & 107 & 134 & 480 & 2001 & 417 & 810 & 2906 \\
\hline CETA & 5400 & 494 & 9 & 1305 & 0 & 0 & 900 & 728 & 81 & 7605 & 1222 \\
\hline CHIETA & 1000 & 1534 & 153 & 50 & 79 & 158 & 500 & 1199 & 240 & 1550 & 2812 \\
\hline ETDP SETA & 750 & 783 & 104 & 210 & 58 & 28 & 0 & 159 & 0 & 960 & 1000 \\
\hline EWSETA & 3000 & 820 & 27 & 620 & 0 & 0 & 1000 & 0 & 0 & 4620 & 820 \\
\hline FASSET & 2840 & 2026 & 71 & 100 & 48 & 48 & 875 & 0 & 0 & 3815 & 2074 \\
\hline FOODBEV & 400 & 352 & 88 & 260 & 124 & 48 & 0 & 0 & 0 & 660 & 476 \\
\hline FP\&M SETA & 750 & 572 & 76 & 166 & 20 & 12 & 450 & 633 & 141 & 1366 & 1225 \\
\hline HWSETA & 2760 & 3777 & 137 & 80 & 155 & 194 & 800 & 138 & 17 & 3640 & 4070 \\
\hline INSETA & 1400 & 465 & 33 & 1295 & 188 & 15 & 700 & 182 & 26 & 3395 & 835 \\
\hline LGSETA & 1500 & 384 & 26 & 70 & 0 & 0 & 1600 & 0 & 0 & 3170 & 384 \\
\hline MERSETA & 1600 & 1786 & 112 & 110 & 231 & 210 & 1690 & 2265 & 134 & 3400 & 4282 \\
\hline MICT SETA & 1750 & 2293 & 131 & 300 & 495 & 165 & 948 & 946 & 100 & 2998 & 3734 \\
\hline MQA & 1500 & 984 & 66 & 600 & 0 & 0 & 1200 & 6060 & 505 & 3300 & 7044 \\
\hline PSETA & 81 & 42 & 52 & 67 & 465 & 694 & 0 & 0 & 0 & 148 & 507 \\
\hline SASSETA & 960 & 1576 & 164 & 240 & 20 & 8 & 1200 & 0 & 0 & 2400 & 1596 \\
\hline SERVICES & 6500 & 0 & 0 & 2795 & 0 & 0 & 2000 & 0 & 0 & 11295 & 0 \\
\hline TETA & 430 & 519 & 121 & 250 & 19 & 8 & 550 & 645 & 117 & 1230 & 1183 \\
\hline W\&RSETA & 1681 & 2705 & 161 & 0 & 0 & 0 & 644 & 520 & 81 & 2325 & 3225 \\
\hline Total & 35463 & 23823 & 67 & 8846 & 2510 & 28 & 18595 & 18787 & 101 & 62904 & 45120 \\
\hline
\end{tabular}

Source: SETA Quarterly Reports, 2013/14.

Note 1: The category "Learnerships" refers to a learning programme that leads to an occupational qualification or part-qualification and includes an apprenticeship and cadetship.

Note 2: The category "Internships" refers to the structured work experience component of an occupational qualification registered by the QCTO.

Note 3: The category "Skills Programmes" refers to a part-qualification as defined in the NQFAct, 2008 (Act No. 67 of 2008).

Table 60 shows that, in 2013/14, a total of 45120 unemployed persons were certificated in SETA- supported learning programmes. More than half of all unemployed persons involved in SETA-supported learning programmes were certificated in learnerships, while 18787 learners were certificated in skills programmes in 2013/14.

In general, SETAs did not meet their set targets for learnerships and internships in 2013/14; only skills programmes exceeded their target by $1 \%$. 


\subsection{ARTISANS}

\subsubsection{Introduction}

A national artisan development programme including all components of artisan development driven by all social partners in a coordinated and integrated manner is a critical need for skills development in the country. In recognition of this critical need, the Minister of Higher Education and Training declared 2013 the Year of the Artisan. The 2013 Year of the Artisan has been expanded to become the 2014 Decade of the Artisan launched by the Deputy Minister of Higher Education and Training on 3 February 2014. The Decade of the Artisan will focus on greater involvement of employers and workplaces in artisan development.

The White Paper for Post-School Education and Training: Building an Expanded, Effective and Integrated PostSchool System, as approved by Cabinet on 20 November 2013, also stresses the need for artisan development. The executive summary of the White Paper states the following:

In areas of work such as the artisan trades, apprenticeships have traditionally been the pathway to qualifications; however, the apprenticeship system has been allowed to deteriorate since the mid-1980s, resulting in a shortage of mid-level skills in the engineering and construction fields. Re-establishing a good artisan training system is an urgent priority; the current target is for the country to produce 30000 artisans a year by 2030.

With this focus on artisan development the Department has started to see a steady increase in the number of learners registering for and completing artisanal training in the last three years. Tables 61 and 62 show this trend. 


\subsubsection{Learners entering artisanal learning programmes}

Table 61: Number of learners entering artisanal learning programmes, by organisation, from 2011/12 to 2013/14

\begin{tabular}{|c|c|c|c|}
\hline SETA & $2011 / 12$ & $2012 / 13$ & $2013 / 14$ \\
\hline AGRISETA & 96 & 70 & 116 \\
\hline CATHSSETA & 563 & 662 & 312 \\
\hline CETA & 1849 & 579 & 1342 \\
\hline CHIETA & 2541 & 1989 & 1694 \\
\hline EWSETA & 1046 & 1316 & 390 \\
\hline FOODBEV & 15 & - & 267 \\
\hline FP\&M SETA & 351 & 584 & 426 \\
\hline HWSETA & - & - & - \\
\hline INDLELA & 5227 & 5795 & 7865 \\
\hline LGSETA & 413 & 528 & 294 \\
\hline MERSETA & 6254 & 4951 & 10394 \\
\hline MQA & 2525 & 2365 & 2468 \\
\hline PSETA & 78 & 53 & 2 \\
\hline SASSETA & - & 516 & 385 \\
\hline SERVICES & 2104 & 984 & 968 \\
\hline TETA & 1019 & 711 & 538 \\
\hline W\&RSETA & 334 & 746 & 209 \\
\hline Total & 24415 & 21849 & 27670 \\
\hline
\end{tabular}

Source: National Artisan Development Support Centre (NADSC)-National Artisan Development (NAD) database management system, 2013.

Note 1: Dash (-) means that data is not available.

Note 2: An artisanal learning programme includes an apprenticeship, learnership, skills programme, internship, cadetship or any other programme undertaken at the workplace that is undertaken in preparation of an occupation that is part of the official list of artisan occupations as per Schedule 2, Gazette No. 35625 , dated 31 August 2012.

Note 3: An artisan is a person who has been certified as competent to perform a listed trade in accordance with the Skills Development Act, 1998 (Act No. 97 of 1998).

More than 27000 learners entered artisanal learning programmes in 2013/14 compared with 21849 in 2012/13 and 24415 in 2011/12. The Manufacturing, Engineering and Related Services Sector Education and Training Authority (MERSETA) recorded the highest number of persons who entered artisanal learning programmes (more than 10000 ), followed closely by the Institute for the National Development of Learnerships, Employment Skills and Labour Assessments (INDLELA), which had close to 8000 learners.

Combined, MERSETA and INDLELA supported more than half of all students who entered artisanal learning programmes in 2013/14. 


\subsubsection{Learners completing artisanal learning programmes}

Table 62: Number of learners completing artisanal learning programmes by organisation, from 2011/12 to 2013/14

\begin{tabular}{|c|c|c|c|}
\hline SETA & $2011 / 12$ & $2012 / 13$ & $2013 / 14$ \\
\hline AGRISETA & 77 & 149 & 100 \\
\hline CATHSSETA & 282 & 1007 & 1161 \\
\hline CETA & 699 & 520 & 9 \\
\hline CHIETA & 989 & 1279 & 387 \\
\hline EWSETA & 571 & 37 & 1841 \\
\hline FOODBEV & 160 & 36 & 168 \\
\hline FP\&M SETA & - & - & 4 \\
\hline HWSETA & - & - & - \\
\hline INDLELA & 3392 & 1355 & 2077 \\
\hline LGSETA & 226 & 305 & 81 \\
\hline MERSETA & 3155 & 7166 & 7522 \\
\hline MQA & 2566 & 2035 & 3597 \\
\hline PSETA & 1 & 5 & - \\
\hline SASSETA & - & - & 101 \\
\hline SERVICES & 1521 & 841 & 185 \\
\hline TETA & 208 & 169 & 478 \\
\hline W\&RSETA & 176 & 373 & 399 \\
\hline Total & 14023 & 15277 & 18110 \\
\hline
\end{tabular}

Source: National Artisan Development Support Centre (NADSC)-National Artisan Development (NAD) database management system, 2013.

Note: Dash (-) means that data is not available.

More than 18000 learners completed artisanal programmes in 2013/14, compared with 15277 in 2012/13 and 14023 in 2011/12. MERSETA and the Mining Qualifications Authority (MQA) had the highest number of learners who completed their artisanal training programmes in 2013/14, while the Energy and Water Sector Education and Training Authority (EWSETA) and MQA had the highest increase in the number of learners who completed their artisanal programmes in 2013/14, compared with preceding years.

Combined, MERSETA and MQA supported more than half of all students who completed their artisanal learning programmes in 2013/14. 
Table 63: Number of artisans certificated by SETAs and INDLELA, by economic sector, in 2013

\begin{tabular}{|c|c|c|}
\hline SETA & Economic Sector & Certificated \\
\hline AGRISETA & Agriculture & 149 \\
\hline CATHSSETA & Culture, Arts, Tourism, Hospitality and Sport & 1007 \\
\hline CETA & Construction & 520 \\
\hline CHIETA & Chemicals & 1279 \\
\hline ETDPSETA & Education and Training & - \\
\hline EWSETA & Energy and Water & 37 \\
\hline FOODBEV & Food Processing & 36 \\
\hline FP\&M SETA & Fibre Processing and Manufacturing & - \\
\hline HWSETA & Health and Welfare & - \\
\hline INDLELA & Non-SETA Candidates & 1355 \\
\hline LGSETA & Local Government & 305 \\
\hline MERSETA & Manufacturing and Engineering & 7166 \\
\hline MICT SETA & Media, Information and Communication & - \\
\hline MQA & Mining and Minerals & 2035 \\
\hline PSETA & National and Provincial Government & 5 \\
\hline SASSETA & Safety and Security & - \\
\hline SERVICES & Services Sector & 841 \\
\hline TETA & Transport & 169 \\
\hline W\&RSETA & Wholesale and Retail SETA & 373 \\
\hline Total & & 15277 \\
\hline
\end{tabular}

Source: SETA Monthly Reports, 2013.

Note: Dash (-) means that data is not available.

Table 63 indicates that 15277 artisans were certificated by SETAs and INDLELA in 2013. MERSETA certificated the highest number of artisans at 7166 , followed by MQA. 


\section{FUNDING IN THE POST-SCHOOL EDUCATION AND TRAINING (PSET) SECTOR}

\section{$7.1 \quad$ INTRODUCTION}

Public PSET institutions, namely Higher Education Institutions (HEIs), Further Education and Training/Technical and Vocational Education and Training (FET/TVET) Colleges and Adult Education and Training (AET) Centres are funded largely through public funds and student fees.

Public HEls are funded directly by the Department of Higher Education and Training (DHET), while the processes of funding public FET/TVET Colleges are more complex, following the constitutional amendment to shift the function of the Colleges from the provincial sphere of government to the national sphere. In 2013, AET Centres were administered and funded by Provincial Education Departments (PEDs).

The allocation of funds to public HEls is based on a number of criteria and planning processes, including student enrolment planning processes, while that for public FET/TVET Colleges is based on national norms and standards. Public HEls receive Block Grants that are used to fund the operational costs of teaching and learning and are under the control of University Councils, while earmarked grants are geared towards ensuring that Universities address national priorities. On average for the system, these grants constitute $40 \%$ of the income of Universities. Universities generate other income from fees, research and donor funding, etc.

Funding for public FET/TVET Colleges takes into account, inter alia: the type of programmes offered, student enrolment numbers, the cost of delivery, the need for capital infrastructure and the ability of Colleges to utilise resources efficiently. In the 2013/14 financial year, public FET/TVET Colleges received funding directly from the DHET in the form of subsidies, while PEDs received funding from the DHET in the form of conditional grants. The latter was undertaken to compensate PEDs for salaries paid to FET/TVET College lecturers who were still on the PED PERSAL system. In the 2011/12 and 2012/13 financial years, the DHET transferred funds to PEDs, which in turn administered public FET/TVET Colleges.

Until 2013, public AET Centres were funded and administered by PEDs through existing national and provincial budgeting processes. This situation will change when the legislation to establish Community Colleges takes effect. 


\subsection{FUNDING OF KEY PSET PUBLIC INSTITUTIONS}

Table 64: Funding of key PSET institutions, from 2011/12 to 2013/14

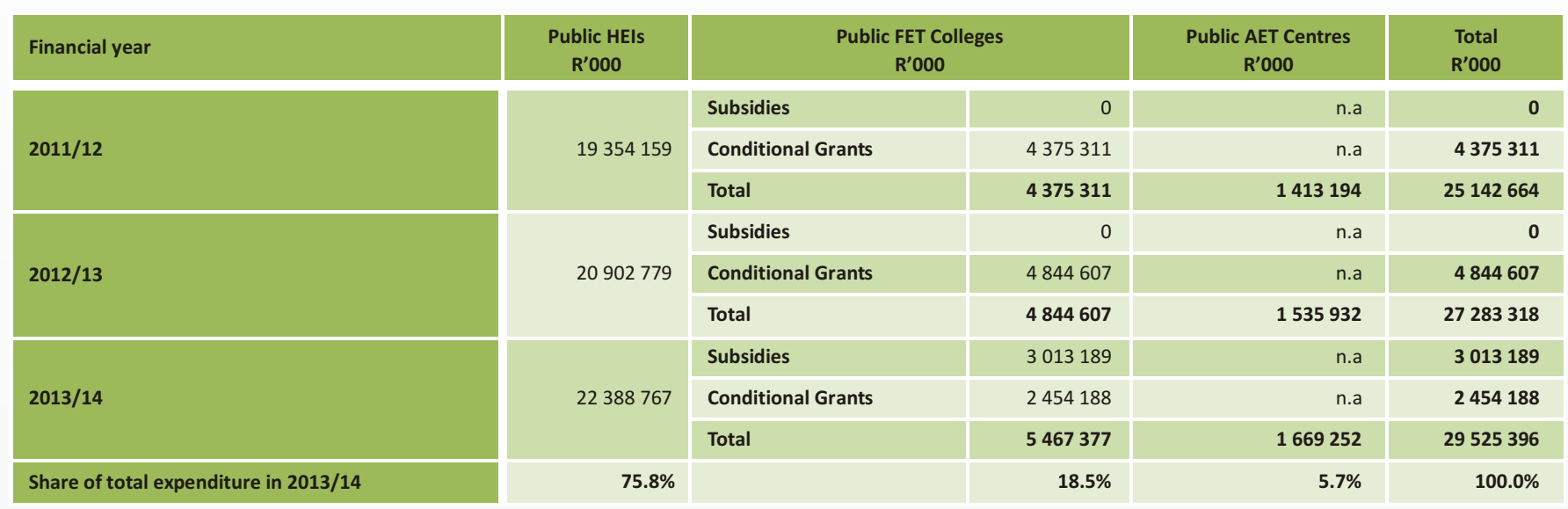

Source: National Treasury website.

Note 1: The amount for public HEls reflects funds transferred directly by the DHET to HEIs.

Note 2: For the 2011/12 and 2012/13 financial years, the amount for public FET/TVET Colleges reflects funds transferred by the DHET to PEDs in the form of conditional grants. The 2013/14 figures for public FET/TVET Colleges show a subsidy amount that was transferred directly from the DHET to FET/TVET Colleges as well as a conditional grant amount that was transferred from the DHET to PEDs.

Note 3: The amount for AET Centres reflects funds transferred from PEDs to AET Centres. The amount reflected for 2012/13 is the budgeted amount (and not the expenditure amount), since the final audited data for this sector was not available at the date of publication.

Note 4: "n.a." means not applicable.

Note 5: Allocations above exclude National Student Financial Aid Scheme (NSFAS) allocations.

Table 64 indicates the funding allocated to public HEls, public FET/TVET Colleges and public AET Centres.

The DHET provided grants of over R22 billion to public HEIs, and about R5.5 billion for the public FET/TVET College sector in the 2013/14 financial year, while PEDs spent close to R1.7 billion on the AET sector in the 2013/14 financial year. In effect, close to R30 billion was spent on public HEls, public FET/TVET Colleges and public AET Centres in the 2013/14 financial year, an increase of about R5 billion since 2011/12.

The proportion of funding provided to public HEls, the public FET/TVET College sector and the AET sector was $76 \%$, $18 \%$ and $6 \%$, respectively. 


\subsubsection{Introduction}

NSFAS is a loan and bursary scheme funded by the DHET for disadvantaged students who do not have the financial means to fund their studies at HEIs or FET/TVET Colleges. NSFAS is administered by and accessible through HEls and FET/TVET Colleges.

In terms of the NSFAS Act, 1999 (Act No. 56 of 1999), the functions of NSFAS are stated as follows:

- To allocate funds for loans and bursaries ${ }^{2}$ to eligible students;

- To develop criteria and conditions for the granting of loans and bursaries to eligible students in consultation with the Minister;

- To raise funds as contemplated in section 14(1) of the NSFAS Act;

- To recoverloans;

- To maintain and analyse a database and undertake research for the better utilisation of financial resources;

- To advise the Minister on matters relating to student financial aid; and

- $\quad$ To perform other functions assigned to it by the NSFAS Act or by the Minister.

\subsubsection{NSFAS beneficiaries and amount provided}

Table 65: Number of students who received loans/bursaries from NSFAS and the amount provided, by sub-sector, from 2011 to 2013

\begin{tabular}{|c|c|c|c|c|c|c|c|}
\hline \multirow[b]{2}{*}{ Year } & \multicolumn{2}{|c|}{ Public HEls } & \multicolumn{2}{|c|}{ Public FET Colleges } & \multicolumn{2}{|c|}{ Total } & \multirow{2}{*}{$\begin{array}{c}\text { Percentage } \\
\text { change on } \\
\text { amount } \\
\text { provided }\end{array}$} \\
\hline & $\begin{array}{l}\text { Number of } \\
\text { students }\end{array}$ & $\begin{array}{l}\text { Amount } \\
\text { provided } \\
R^{\prime} 000\end{array}$ & $\begin{array}{l}\text { Number of } \\
\text { students }\end{array}$ & $\begin{array}{l}\text { Amount } \\
\text { provided } \\
R^{\prime} 000\end{array}$ & $\begin{array}{l}\text { Number of } \\
\text { students }\end{array}$ & $\begin{array}{l}\text { Amount } \\
\text { provided } \\
R^{\prime} 000\end{array}$ & \\
\hline 2011 & 173927 & 4561359562 & 114971 & 1116767169 & 288898 & 5678126731 & 55 \\
\hline 2012 & 194504 & 5871489880 & 188182 & 1822497265 & 382686 & 7693987145 & 35.5 \\
\hline 2013 & 194923 & 6729069970 & 220978 & 1953253361 & 415901 & 8682323331 & 12.8 \\
\hline
\end{tabular}

Source: NSFAS Annual Reports (2011/12; 2012/13;2013/14).

Close to 416000 students received a bursary or loan from NSFAS in the 2013 academic year, a significant increase since 2011 when fewer than 289000 students benefitted from the Scheme. In 2013, over 220000 FET/TVET College students received a loan or bursary from NSFAS, while about $195000 \mathrm{HEl}$ students benefited from NSFAS. Table 65 shows that the number of FET/TVET College students benefitting from NSFAS increased dramatically since 2011 from about 115000 in 2011 to more than 221000 in 2013. By 2013, the number of FET/TVET College students benefitting from NSFAS exceeded the number of HEI students who received NSFAS loans and bursaries.

${ }^{2}$ The term "loans" refers to a loan granted to a person by NSFAS to enable the person to defray the costs of his or her education at a designated HEI and the costs connected with the board and lodging of that person for purposes of attending the institution. The term "bursaries" refers to that part of the loan granted to a person by NSFAS that the person is not required to pay back on compliance with the criteria and conditions set out in a written agreement. 
NSFAS dispensed close to R 8.7 billion in loans or bursaries in the 2013 academic year, an increase of $12.8 \%$ from the previous year. Table 65 shows significant increases in the amount of funds spent on loans or bursaries since 2011, with expenditure in 2012 about 36\% higher than in 2011.

\subsubsection{Funza Lushaka bursary scheme}

The Funza Lushaka bursary scheme is a special multi-year programme established to incentivise high-achieving students to study to become teachers. It provides financial support to students for the entire duration of the programme linked to a full teaching qualification, either the Bachelor of Education Degree, or a general Undergraduate Bachelor's Degree with suitable subjects that enable the teaching of school subjects. The general Undergraduate Degree must be followed by a Postgraduate Certificate in Education. Students specialising in national priority areas, such as Mathematics, Science and the Foundation Phase, are most often beneficiaries of the Funza Lushaka bursary scheme. The scheme is managed by the Department of Basic Education. Further information about the scheme can be obtained from www.funzalushaka.doe.gov.za

Table 66: Number of students in HEls who received a Funza Lushaka bursary and the amount provided, from 2011 to 2013

\begin{tabular}{|c|c|c|c|c|}
\hline Year & $\begin{array}{l}\text { Number of students enrolled } \\
\text { in the Education Field }\end{array}$ & $\begin{array}{c}\text { Number of students who received a } \\
\text { Funza Lushaka bursary }\end{array}$ & $\begin{array}{c}\text { Percentage of students who received } \\
\text { a Funza Lushaka bursary }\end{array}$ & $\begin{array}{l}\text { Amount provided } \\
\text { (in Rands) }\end{array}$ \\
\hline 2011 & 164939 & 8893 & 5.4 & 442846392 \\
\hline 2012 & 168608 & 11702 & 6.9 & 666782495 \\
\hline 2013 & 172991 & 14473 & 8.4 & 890104296 \\
\hline
\end{tabular}

Source: NSFAS Annual Reports (2011/12; 2012/13;2013/14).

More than 14000 students received a Funza Lushaka bursary in 2013, compared with about 9000 in 2011. Funza Lushaka beneficiaries comprised over $8 \%$ of all students enrolled in the field of education in 2013. Table 66 shows that the percentage of "education" students who benefited from the Funza Lushaka bursary scheme increased from about $5 \%$ in 2011 to over $8 \%$ in 2013.

The Funza Lushaka bursary scheme dispensed almost R900 million in 2013, more than double the amount spent in 2011 when the amount spent was about R443 million. 


\subsection{THE SKILLS DEVELOPMENT LEVY}

\subsubsection{Introduction}

The Skills Development Levy is a form of tax collected from employers on an ongoing basis in terms of the Skills Development Levies Act, 1999 (Act No. 9 of 1999). The Skills Development Levy, which is calculated as 1\% of the employer's payroll, is collected by the South African Revenue Service (SARS) on a monthly basis. The DHET receives this income from SARS and distributes it to the Sector Education and Training Authorities (SETAs) and the National Skills Fund (NSF) on a monthly basis. SETAs (as a whole) receive $80 \%$ of the income from the Skills Levy Development Fund, while the NSF receives 20\%. The Skills Development Levy is regulated by the following acts: Income Tax Act, 1962 (Act No. 58 of 1962), Skills Development Levies Act, 1999 (Act No. 9 of 1999), Skills Development Act, 1998 (Act No. 97 of 1998) and the Tax Administration Act, 2011 (Act No. 28 of 2011).

\subsubsection{Distribution of the Skills Development Levy}

Table 67: Distribution of the Skills Development Levy, from 2011/12 to 2013/14

\begin{tabular}{|c|c|c|c|c|c|c|}
\hline \multirow{3}{*}{ Year } & \multirow{3}{*}{$\begin{array}{c}\text { Total amount } \\
\text { disbursed by } \\
\text { the Skills } \\
\text { Development Levy } \\
\text { R'000 }\end{array}$} & \multicolumn{5}{|c|}{ Distribution of Skills Development Levy } \\
\hline & & \multirow{2}{*}{$\begin{array}{c}\text { NSF } \\
\text { R'000 }^{\prime}\end{array}$} & \multirow{2}{*}{$\begin{array}{l}\text { Amount disbursed } \\
\text { to SETAs } \\
\text { R'000 }\end{array}$} & \multicolumn{3}{|c|}{ SETAs } \\
\hline & & & & $\begin{array}{l}\text { Administration costs } \\
\text { R'000 }\end{array}$ & $\begin{array}{l}\text { Mandatory Grant } \\
\text { R'000 }\end{array}$ & $\begin{array}{l}\text { Discretionary Grant } \\
\text { R'000 }\end{array}$ \\
\hline $2011 / 12$ & 10106213 & 2020029 & 8086184 & 1010773 & 5053865 & 2021546 \\
\hline $2012 / 13$ & 11419342 & 2283872 & 9135470 & 1141934 & 5709669 & 2283867 \\
\hline $2013 / 14$ & 12566290 & 2511391 & 10054899 & 1319706 & 2513725 & 6221469 \\
\hline
\end{tabular}

Source: DHET Annual Financial Statements for the financial years ending 2011, 2012, 2013 and 2014.

Note 1: "NSF" refers to the funds disbursed by the NSF (see Table 69 for further information).

Note 2: "Administration costs" refer to administration costs incurred by SETAs, as approved by a SETA Accounting Authority.

Note 3: "Mandatory Grant" refers to the grant a SETA pays to an employer on receipt of the employer's Workplace Skills Plan in terms of Section 4 of the Skills Development Act, 1998 (Act No. 97 of 1998).

Note 4: "Discretionary Grant" refers to the grant a SETA pays to an employer in support of the SETA Sector Skills Plan in terms of Section 6 of the Skills Development Act, 1998 (Act No. 97 of 1998).

The Skills Development Levy disbursed close to R 12.6 billion in the 2013/14 financial year, up from R10.1 billion in 2011/12. Eighty percent of funds from the Skills Development Levy was distributed to SETAs and $20 \%$ to the NSF for each of the three financial years. The NSF received more than R2.5 billion in the 2013/14 financial year, an increase from about R2 billion in 2011/12. The SETAs received more than R10 billion in 2013/14, an increase from over R8 billion in 2011/12. Of the approximately R10 billion received by SETAs in 2013/14, about R1.3 billion was utilised by SETAs for administration purposes, R2.5 billion for the Mandatory Grant and R6.2 billion for the Discretionary Grant.

Table 67 also indicates that the Mandatory Grant for 2013/14 was lower than in previous years, whereas the Discretionary Grant was higher. The Minister of Higher Education and Training gazetted the amended SETA Grant Regulations in December 2012 for implementation on 1 April 2013. The amendment adjusted the Mandatory Grant from $50 \%$ to $20 \%$, the Discretionary Grant from $20 \%$ to $49.5 \%$ and administration costs to $10.5 \%$ from $10 \%$. 


\subsection{GRANTS PROVIDED BY THE NATIONAL SKILLS FUND (NSF)}

\subsubsection{Introduction}

The NSF was established in terms of the Skills Development Act, 1998 (Act No. 97 of 1998). It is resourced from Skills Development Levies that employers submit to the government in terms of the Skills Development Levies Act, 1999 (Act No. 9 of 1999). National skills funds are disbursed in line with the strategic framework and criteria for the allocation of funds as approved by the Minister of Higher Education and Training on advice provided by the National Skills Authority (NSA) in accordance with Section 5(1)(a)(iv) of the Skills Development Act, 1998 (Act No. 97 of 1998).

The Skills Development Act stipulates that the NSF may fund the following:

- $\quad$ Skills development projects identified in the National Skills Development Strategy (NSDS III) as national priorities;

- Skills development projects related to the achievement of the purposes of the Skills Development Act, 1998 (Act No. 97 of 1998); and

- Any activity undertaken by the Minister to achieve a national standard of good practice in skills development.

The tables below provide an overview of the number of projects supported by the NSF, as well as the distribution of funds across key projects.

\subsubsection{Number of projects and beneficiaries supported by the NSF}

Table 68: Number of NSF-supported projects and beneficiaries, by province, from 2011/12 to 2013/14

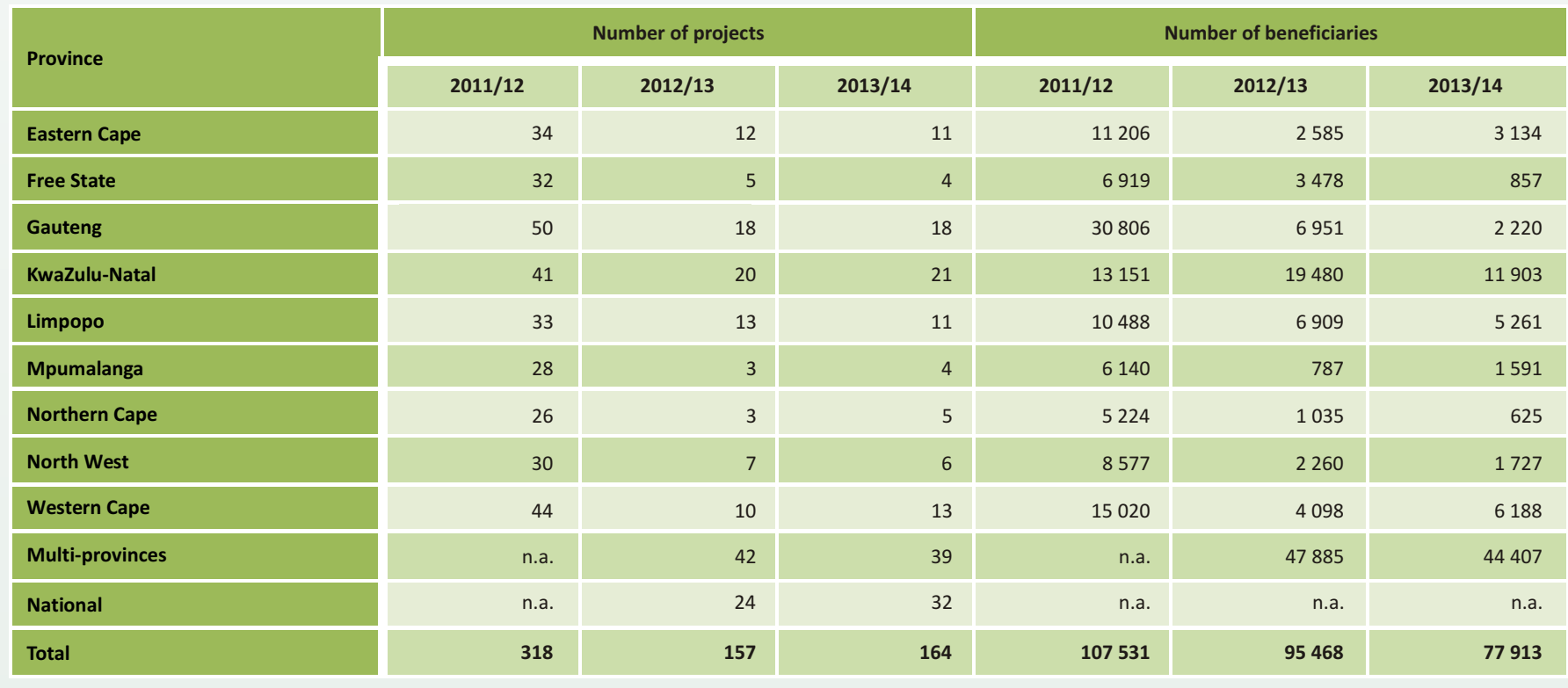

Source: DHET (2014). NSF Organisational Report, DHET 2014.

Note 1: "n.a." means "not applicable".

Note 2: The number of beneficiaries include students who were awarded bursaries by channeling NSF funds via NSFAS, the National Research Foundation (NRF) and Career Wise.

Table 68 illustrates the distribution of the number of national, individual province and multi-province skills development projects supported by the NSF. It also indicates the number of persons benefiting from skills development projects supported by the NSF. 
The NSF supported 164 skills development projects across South Africa during the 2013/14 financial year. The majority of these were located at provincial level, while 32 were national projects. Key national projects supported by the NSF include: the National Artisan Moderation Body - National Artisan Development (NAMB-NAD) Support Centre for national artisan development; the Recognition of Prior Learning (RPL) Project of INDLELA; the Labour Market Intelligence Project; Green and White Paper processes on PSET; and Ministerial Task Teams on interventions related to skills development.

As can be seen in Table 68, the number of skills projects funded from the NSF declined significantly between the 2011/12 and 2013/14 financial years. This was largely due to the refocusing of NSF funding towards priority projects on PSET.

Table 69: Distribution of NSF across key projects, number of beneficiaries and amount disbursed, from 2011/12 to 2013/14

\begin{tabular}{|c|c|c|c|c|c|c|c|}
\hline \multirow{2}{*}{ Project } & \multicolumn{3}{|c|}{ Number of beneficiaries } & \multicolumn{3}{|c|}{$\begin{array}{l}\text { Amount disbursed } \\
R^{\prime} 000\end{array}$} & \multirow{2}{*}{$\begin{array}{c}\text { Percentage o } \\
\text { total amount } \\
\text { disbursed } \\
2013 / 14\end{array}$} \\
\hline & $2011 / 12$ & $2012 / 13$ & $2013 / 14$ & 2011/12 & $2012 / 13$ & $2013 / 14$ & \\
\hline Bursaries & 6374 & 15804 & 30162 & 799199 & 1238398 & 1272200 & 40.5 \\
\hline NSF disbursement to FET Colleges & - & 34528 & 25850 & - & 438258 & 495031 & 15.8 \\
\hline Support to NGP (public and private) & 6218 & 9817 & 9238 & 166347 & 223775 & 428456 & 13.7 \\
\hline Support to IPAP (public) & 1254 & 3495 & 626 & 65470 & 43385 & 64800 & 2 \\
\hline Rural development & 10854 & 2634 & 3156 & 30163 & 113017 & 101008 & 3.2 \\
\hline Other national priorities & 82803 & 29190 & 8881 & 243770 & 518295 & 776996 & 24.8 \\
\hline Total & 107503 & 95468 & 77913 & 1304949 & 2575125 & 3138491 & 100 \\
\hline
\end{tabular}

Source: NSF audited financial statements for the years ending 31 March 2011, 2012 and 2013.

Note 1: The NSF provides bursaries to students via NSFAS, the NRF and Career Wise.

Note 2: Full details regarding the NSF expenditure and performance information are in the NSF Annual Report 2012/13.

Note 3: Dash (-) means that data is not available.

Note 4: Certain disbursed amounts stated under "Amount disbursed" NSDS III for 2012/13 have changed in accordance with the restated figures in the NSF Annual Financial Statements for the year ending 31 March 2014.

As indicated in Table 69, the NSF disbursed more than R3 billion in the 2013/14 financial year, a significant increase since 2011/12, when about R1.3 billion was disbursed. In 2013/14, more than 40\% of all NSF funds were used for student bursaries, which were dispensed through NSFAS, the National Research Foundation (NRF) and Career Wise. As indicated in the NSF Organisational Report (DHET 2013), about 95\% of these bursaries were allocated to students enrolled in HEls. Table 69 shows a significant increase in the amount of NSF funding allocated for student bursaries since 2011/12 - from about R800 million in 2011/12 to over R1.2 billion in 2013/14. This dramatic growth can be attributed to policy shifts, which place greater emphasis on an integrated PSET system as envisioned in the White Paper for Post-School Education and Training (DHET 2013).

Table 69 shows that of the 77913 persons who benefited directly from NSF support in 2013/14, 25850 were public FET/TVET College students and 30162 were public HEl students. The latter received Undergraduate and Postgraduate bursaries in scarce skills fields of study. Disbursements were made to FET/TVET Colleges to compensate for unplanned student enrolment and capacity building programmes. Other beneficiaries were supported by the NSF through skills development programmes, such as artisan development programmes and learnerships to support the National Growth Path (NGP), the Industrial Policy Action Plan (IPAP), rural development and other national priorities. 


\subsubsection{NSF infrastructure grants}

Table 70: Distribution of NSF infrastructure budget, in 2013/14

\begin{tabular}{|c|c|c|c|}
\hline & $\begin{array}{c}\text { HEIs } \\
\text { R'000 }^{\prime}\end{array}$ & $\begin{array}{l}\text { Other } \\
\text { R'000 }^{\prime}\end{array}$ & $\begin{array}{l}\text { Total } \\
\text { R'000 }^{\prime}\end{array}$ \\
\hline Amount disbursed & 275061 & 28104 & 303165 \\
\hline
\end{tabular}

Source: NSF audited financial statements for the year ending 31 March 2013 (page 93 of the NSF Annual Report 2013/14).

Note: "Other" includes institutions other than government.

In addition to supporting $\mathrm{HEI}$ and FET/TVET College students with bursaries, the NSF prioritised allocations to expand and improve the infrastructure of public HEls, public FET/TVET Colleges and public AET Centres, and to support the improvement of infrastructure at state-owned enterprises. To this end, the NSF disbursed more than R303 million towards skills infrastructure development as a national priority of government during the 2013/14 financial year. As indicated in Table 70, a very significant part of the NSF infrastructure budget (more than R275 million) was distributed to HEIs in 2013/14.

The NSF Annual Report 2013/14 (DHET 2014), indicates that of the funding distributed to public HEls for infrastructure in 2013/14, R105.9 million was disbursed to the University of Pretoria to expand its medical and veterinary facilities. Furthermore, R96.1 million was disbursed to the University of Johannesburg to establish work-integrated learning facilities for engineering students, which includes a training workshop, design centre and an industrialisation centre. R8.5 million was disbursed to the Cape Peninsula University of Technology for the establishment of renewable energy training facilities. These facilities are critical for the production of a set of new skills required for the green economy.

Funds were also disbursed for the planning, development and refurbishment of 16 FET/TVET College campuses (12 new and four existing campuses).

The physical construction of the 12 new FET/TVET College campuses has begun in the 2014 financial year.

R28 million was used to build hostels and lecture rooms for deaf students and accommodation for hostel managers at the National Institute for the Deaf (NID), which is the only community-based tertiary education institute for deaf people in South Africa. 


\section{EXPLANATORY NOTES}

\section{$8.1 \quad$ INTRODUCTION}

These explanatory notes provide information about data sources and some methodological issues pertaining to the surveys conducted by the Department of Higher Education and Training (DHET) to obtain data for this publication.

\subsection{SCOPE}

Information for this publication was provided by the following education and training institutions and entities:

- Public and private Higher Education Institutions (HEIs);

- Public Further Education and Training/Technical and Vocational Education and Training (FET/TVET) Colleges and private FET Colleges;

- Public and private Adult Education and Training (AET) Centres;

- $\quad$ Sector Education and Training Authorities (SETAs);

- The National Student Financial Aid Scheme (NSFAS);

- The National Artisan Moderation Body (NAMB); and

- $\quad$ The National Skills Fund (NSF).

\subsection{METHODOLOGY}

Data pertaining to AET Centres and FET/TVET Colleges are provided to the Department in an aggregated format (that is, unit record data is not available), while HEls submit unit record data directly to the Department in accordance with the format prescribed to HEls by the Department. SETAs, NAMB and the NSF provide aggregated data to the Department. The Department develops and implements policy, standards, definitions and classifications for the aggregation of and standardisation and uniformity in the collection of education information from provinces.

\subsection{RESPONSE RATES}

The response rates to questionnaires sent to education and training institutions by the Department and Provincial Education Departments (PEDs) with respect to 2013 data are as follows:

- $\quad$ Public HEls: $100 \%$.

- $\quad$ Private HEls: $99 \%$.

- Public FET/TVET Colleges: $100 \%$.

- $\quad$ Private FET Colleges: $64 \%$.

- Public AET Centres: 56\%. 


\section{GLOSSARY}

\section{Administrative staff}

All technical and office staff, as well as all executive and professional staff who spend less than $50 \%$ of their official time on administrative functions. Adapted from the Department of Education $(1982,1995)$ Manual: South African PostSecondaryEducation (SAPSE). Pretoria.

\section{Adult Education and Training (AET)}

All learning and training programmes for adults at Level 1, registered on the National Qualifications Framework (NQF) contemplated in the National Qualifications Framework Act, 2008 (Act No. 67 of 2008). South Africa (2000) Adult Education and Training Act, No. 52 of 2000 (as amended). Pretoria.

\section{Adult Education and Training (AET) Centre}

A public or private centre. South Africa (2000) Adult Education and Training Act, No. 52 of 2000 (as amended). Pretoria.

\section{Apprenticeship}

A learnership in respect of a listed trade, and includes a trade test in respect of that trade. South Africa (2000). South Africa (1998) Skills Development Act, No. 97 of 1998 (as amended). Pretoria.

\section{Artisan}

A person who has been certified as competent to perform a listed trade in accordance with the Skills Development Act, 1998 (Act No. 97 of 1998). South Africa (1998) Skills Development Act, No. 97 of 1998 (as amended). Pretoria.

\section{Bursary}

That part of a loan granted to a person by the National Student Financial Aid Scheme (NSFAS) that the person is not required to pay back on compliance with the criteria and conditions set out in a written agreement. South Africa (1999) National Student Financial Aid Scheme Act, No. 56 of 1999. Pretoria.

\section{Certification}

Formal recognition of a qualification or part-qualification awarded to a successful learner. South African Qualifications Authority (SAQA) (2013) Standard Glossary of Terms: Terms related to the South African National Qualifications Framework. Pretoria.

\section{College}

A public or private Further Education and Training (FET) institution that is established, declared or registered under the Further Education and Training Colleges Act, 2006 (Act No. 16 of 2006), but does not include:

(a) a school offering Further Education and Training (FET) programmes under the South African Schools Act, 1996 (Act No. 84 of 1996); or

(b) a college under the authority of a government department other than the Department of Education. South Africa (2006) Further Education and Training Colleges Act, No. 16 of 2006 (as amended). Pretoria.

\section{Comprehensive University}

A type of public Higher Education Institution (HEI) established through the merger of a former technikon with a traditional university. 


\section{Contact student}

A student in a Higher Education Institution (HEI) who is registered mainly for courses offered in contact mode. A contact mode course involves personal interaction with lecturers or supervisors through lectures, tutorials, seminars, practicals, supervision or other forms of required work, which is presented on the institution's premises or at a site of the institution. Adapted from Department of Education (1982, 1995) Manual: South African Post-Secondary Education (SAPSE), Pretoria.

\section{Distance student}

A student in a Higher Education Institution (HEI) who is registered mainly for courses offered in distance mode. A distance mode course involves interaction with lecturers, or institution supervisors, through distance education techniques. For example, through the use of correspondence, telematics or the Internet. Adapted from Department of Education (1982, 1995) Manual: South African Post-Secondary Education (SAPSE), Pretoria.

\section{Educator}

Any person who teaches, educates or trains another person, or provides professional educational services, including professional therapy and education psychological services, at any public centre and who is appointed in a post on any educator establishment contemplated in section $20 \mathrm{~F}$ of the Adult Education and Training Act, 2000 (Act No. 52 of 2000). South Africa (2000). Adult Education and Training Act, No. 52 of 2000 (as amended). Pretoria.

\section{Further Education and Training (FET)}

All learning and training programmes leading to qualifications at Levels 2 to 4 of the National Qualifications Framework (NQF) or such further education and training levels determined by South African Qualifications Authority (SAQA) and contemplated in the South African Qualifications Authority Act, 1995 (Act No. 58 of 1995) which levels are above general education but below higher education. South Africa (2006) Further Education and Training Colleges Act, No. 16 of 2006 (as amended). Pretoria.

\section{Full-Time Equivalent (FTE) student}

A student in the post-school sector who is enrolled for an academic programme for a full academic year and who is registered for all the courses included in the curriculum of that programme. If a student is following, for example, only half of the courses required for a full-year academic programme, then he/she would be counted as 0.5 FTE students. If a student is taking $20 \%$ more than the courses required in a standard full-year curriculum, then he/she would be counted as 1.2 FTE students. Adapted from Department of Education $(1982,1995)$ Manual: South African PostSecondary Education (SAPSE).Pretoria.

\section{General Education and Training (GET)}

All learning and training programmes leading to a qualification at Level 1 of the National Qualifications Framework (NQF). South Africa (2001) General and Further Education and Training Quality Assurance Act, No. 58 of 2001 (as updated by Government Gazette No. 34620, 16 September 2011). Pretoria.

\section{General Education and Training Certificate-Adult Basic Education and Training (GETC-ABET) Level 4 qualification}

A qualification at Level 1 of the National Qualifications Framework (NQF). As prescribed in the Adult Education and Training Act, 2000 (Act No. 52 of 2000), the GETC is offered to adults who have not had any formal schooling, or who may not have completed formal basic schooling to the equivalent of NQF Level 1. 


\section{Graduate}

A student who has satisfied all the requirements of the Degree, Diploma or Certificate for which he/she was registered. South African Post-Secondary Education (SAPSE)-020: Student Statistics Manual. Pretoria.

\section{Headcount student}

Total, unduplicated number of students enrolled in a post-secondary education institution at a given census date, regardless of their course load. Department of Education (1995) South African Post-Secondary Education (SAPSE)-005: Student Statistics Manual. Pretoria.

\section{Higher Education Institution (HEI)}

Any institution that provides higher education on a full-time, part-time or distance basis and which is:

(a) Merged, established, or deemed to be established, as a public HEl under the Higher Education Act, 1997 (Act No. 101 of 1997);

(b) Declared as a public HEl under the Higher Education Act, 1997 (Act No. 101 of 1997); or

(c) Registered or provisionally registered as a private HEl under the Higher Education Act, 1997 (Act No. 101 of 1997).

South Africa (1997) Higher Education Act, No. 101 of 1997 (as amended). Pretoria.

\section{Instruction and research staff}

Academic staff who spend more than $50 \%$ of their official time on instruction and research activities. Adapted from the Department of Education (1982, 1995) Manual: South African Post-Secondary Education (SAPSE). Pretoria.

\section{Internship}

The structured work experience component of a qualification registered on the National Qualifications Framework (NQF).

\section{Learner}

Any person receiving education and training in terms of the Adult Education and Training Act, 2000 (Act No. 52 of 2000). South Africa (2000) Adult Education and Training Act, No. 52 of 2000 (as amended). Pretoria.

\section{Learning programme}

Includes a learnership, an apprenticeship, a skills programme and any other prescribed learning programme that includes a structured work experience component. South Africa (1998) Skills Development Act, No. 97 of 1998 (as amended). Pretoria.

\section{Learnership}

A learning programme that leads to an occupational qualification or part-qualification, and includes an apprenticeship and cadetship. South Africa (1998) Skills Development Act, No. 97 of 1998 (as amended). Pretoria.

\section{Lecturer (Further Education and Training/Technical and Vocational Education and Training [FET/ TVET])}

Any person who teaches, educates or trains other persons, or who provides professional educational services at any College, and who is appointed in a post on any lecturer establishment under the Further Education and Training Act, 2006 (Act No. 16 of 2006). South Africa (2006) Further Education and Training Colleges Act, No. 16 of 2006 (as amended). Pretoria. 


\section{Major field of study}

The subject area(s) in which a student may specialise in the final year of study for a Degree/Diploma/Certificate instructional programme. Department of Education (1995) South African Post-Secondary Education (SAPSE)-004: Formal Degree/Diploma/Certificate Programme Classification Structure Manual. Pretoria.

\section{Management staff}

In FET/TVET Colleges, it refers to a principal and vice-principal of a public College. South Africa (2006) Further Education and Training Colleges Act, No. 16 of 2006 (as amended). Pretoria.

In AET Centres, it refers to the Centre Manager of an AET Centre. Department of Higher Education and Training (2012). Annual Survey of Adult Education and Training (AET) Centres.

\section{Master list of institutions}

A list of institutions containing all the contact information of the institution, such as addresses, telephone numbers, GIS coordinates, etc. Adapted from the Department of Higher Education and Training (2012) Higher Education Information Standards DHET 003: Standard for the publication of the master list of education institutions in the postschool sector. Pretoria.

\section{National Certificate (Vocational) (NC [V])}

National qualifications at National Qualifications Framework (NQF) Levels 2, 3 and 4, comprising 130 credits and seven subjects per level, which consist of academic knowledge and theory, integrated with the practical skills and values specific to each vocational area/specialisation. The qualifications comprise both internal and external components of assessment and are quality assured by Umalusi.

\section{Occasional student}

A student who is taking courses that are part of formally approved programmes, but who is not registered for a formal Degree or Diploma. Adapted from the Department of Education $(1982,1995)$ Manual: South African Post-Secondary Education (SAPSE). Pretoria.

\section{Occupational qualification}

A qualification associated with a trade, occupation or profession resulting from work-based learning and consisting of knowledge unit standards, practical unit standards and work-experience unit standards. South Africa (2008) Skills Development Amendment Act, No. 97 of 2008 (as amended). Pretoria.

\section{Permanent staff}

A permanent staff member is defined as an employee who contributes to an institutional pension or retirement fund. Adapted from the Department of Education $(1982,1995)$ Manual: South African Post-Secondary Education (SAPSE). Pretoria.

\section{Population group}

A group with common characteristics (in terms of descent and history), particularly in relation to how they were (or would have been) classified before the 1994 elections. The following categories are provided in the census: African, Coloured, Indian or Asian, White, other. Statistics South Africa (2010) Adapted from Census 2010: Concepts and Definitions. Pretoria. 


\section{Postgraduate, below Master's Level}

Includes postgraduate and post-diploma Diplomas, postgraduate Bachelor's Degrees and Honours Degrees. Adapted from the Department of Education $(1982,1995)$ Manual: South African Post-Secondary Education (SAPSE). Pretoria.

\section{Post-Matric}

Refers to programmes offered to learners who have completed Matric (Grade 12). Adapted from the Department of Education $(1982,1995)$ Manual: South African Post-Secondary Education (SAPSE). Pretoria.

\section{Post-School}

Comprises all education and training provision for those who have completed school, those who did not complete their schooling, and those who never attended school. Department of Higher Education and Training (2013) White Paper for Post-School Education and Training. Pretoria.

\section{Private College}

Any College that provides Further Education and Training (FET) or on a full-time, part-time or distance basis and which is registered or provisionally registered as a private College under the Further Education and Training Colleges Act, 2006 (Act No.16 of 2006). South Africa (2006) Further Education and Training Colleges Act, No. 16 of 2006. Pretoria.

\section{Private Higher Education Institution (HEI)}

Any institution registered or conditionally registered as a private HEl in terms of Chapter 7 of the Higher Education Act, 1997 (Act No. 101 of 1997). South Africa (1997) Higher Education Act, No. 101 of 1997 (as amended). Pretoria.

\section{Public College}

Any College that provides Further Education and Training (FET) on a full-time, part-time or distance basis and which is -

a) Established or regarded as having been established as a public College under the Further Education and Training Colleges Act, 2006 (Act No. 16 of 2006); or

b) Declared as a public College under the Further Education and Training Colleges Act, 2006 (Act No. 16 of 2006) South Africa (1998) Further Education and Training Colleges Act, No. 16 of 2006 (as amended). Pretoria.

\section{Public Higher Education Institution (HEI)}

Any HEl that is established, deemed to be established or declared as a public HEl under the Higher Education Act, 1997 (Act No. 101 of 1997). South Africa (1997) Higher Education Act, No. 101 of 1997 (as amended). Pretoria.

\section{Qualification}

A registered national qualification. South Africa (2008) National Qualifications Framework Act, No. 65 of 2008. Pretoria.

\section{Report 191}

A catalogue of nationally assessed and certificated occupationally-directed programmes aimed at learners intending to pursue a technical/vocational learning pathway outside of the schooling system, and are offered from N1 to N6, with the latter culminating in the National N Diploma on completion of the compulsory workplace experience component. South Africa (2001) National Education Policy: Formal technical instructional programmes in the RSA, Report 191 (2001/08). Pretoria. 


\section{Report 550}

Is a policy resume of instructional programmes offered in schools, containing the programme requirements, which includes the promotion requirements, the special conditions and the rules of combination for the issuing of the Senior Certificate.

\section{South African Qualifications Authority (SAQA)}

The statutory authority established in terms of the SAQA Act, 1995 (Act No. 58 of 1995) and continuing in terms of the National Qualifications Framework (NQF) Act, 2008 (Act No. 67 of 2008), which oversees the further development and implementation of the NQF, the achievement of the objectives of the NQF, and the coordination of the three subframeworks. SAQA (2013) Standard Glossary of Terms: Terms related to the South African National Qualifications Framework. Pretoria.

\section{Service staff (Higher Education Institutions [HEls])}

All staff, such as cleaners, gardeners, security guards and messengers, who are not engaged in supervisory or administrative functions linked to an office. Adapted from the Department of Education $(1982,1995)$ Manual: South African Post-Secondary Education (SAPSE). Pretoria.

\section{Sector Education and Training Authority (SETA)}

A SETA established in terms of Section 9 (1), of the Skills Development Act, 1998 (Act No. 97 of 1998). South Africa (1998) Skills Development Act, No. 97 of 1998. Pretoria.

\section{Skills programme}

A skills programme that:

(a) Is occupationally based;

(b) When completed, will constitute a credit towards a qualification registered in terms of the National Qualifications Framework (NQF) as defined in Section 1 of the South African Qualifications Authority (SAQA) Act, 1995 (Act No. 58 of 1995).

(c) Uses training providers referred to in Section 17(1) (c) of the Skills Development Act, 1998 (Act No. 97 of 1998); and

(d) Complies with the prescribed requirements. South Africa (1998) Skills Development Act, No. 97 of 1998. Pretoria.

\section{Student}

In Higher Education Institutions (HEls), it is any person registered as a student at an HEl. South Africa (1997) Higher Education Act 1997, Act No. 101 of 1997 (as amended). Pretoria.

In Further Education and Training/Technical and Vocational Education and Training (FET/TVET) Colleges, it is any person registered as a student at a College. South Africa (2006) Further Education and Training Colleges Act 2006, Act No. 16 of 2006 (as amended). Pretoria.

\section{Subject pass rate}

Represents the percentage of students who pass a subject. It is calculated by expressing the total number of students who passed (pass + conditional pass) a subject as a percentage of the total number of students who wrote a subject. National Examinations Database, November 2013. Pretoria. 


\section{Support staff}

Staff who render academic support services; student support services; human resource management; financial management; administration; maintenance of buildings and gardens; catering services; and security services. South Africa (2006) Further Education and Training Colleges Act, No. 16 of 2006 (as amended). Pretoria.

\section{Unemployed persons}

Persons who:

a) Were not employed in the reference week of the census survey;

b) Were actively looking for work or trying to start a business in the four weeks preceding the survey interview;

c) Were available for work, i.e. would have been able to start work or a business in the reference week; or

d) Had not actively looked for work in the past four weeks but had a job or business to start at a definite date in the future and were available.

Statistics South Africa (2013) Quarterly Labour Force Survey. Pretoria.

\section{Undergraduate student}

A student enrolled in an undergraduate programme as specified in the Higher Education Qualifications SubFramework (HEQSF).

\section{Undergraduate Diploma or Certificate}

A Diploma or Certificate that does not have a Bachelor's Degree as prerequisite for admission to a programme. Department of Education (1995) South African Post-Secondary Education (SAPSE)-004: Formal Degree/Diploma/Certificate Programme Classification Structure Manual. Pretoria.

\section{Undergraduate Degree}

A qualification that also includes professional Bachelor's Degrees, which are those that have an approved formal time of three or more years. Examples include Degrees such as B Tech, BSc (Engineering), MB ChB and BFA. Adapted from the Department of Education $(1982,1995)$ Manual: South African Post-secondary Education (SAPSE). Pretoria. 


\section{CONTACT DETAILS}

Requests for further information can be communicated to the following persons:

\section{Director: Higher Education Management Information System (HEMIS)}

\section{Ms Jean Skene}

Department of Higher Education and Training

123 Francis Baard Street, Pretoria

Postal Address: Private Bag X174, Pretoria, 0001

Tel.: 0123125099

Fax: 0123211788

Email: skene.j@dhet.gov.za

\section{Director: Private Higher Education Institutions (HEIs)}

\section{Dr Shaheeda Essack}

Department of Higher Education and Training

123 Francis Baard Street, Pretoria

Postal Address: Private Bag X174, Pretoria 0001

Tel.: 0123125444

Fax: 0123246343

Email: essack.s@dhet.gov.za

\author{
Chief Director: Planning and Institutional Support (FET/TVET Colleges) \\ Ms Thembisa Futshane \\ Department of Higher Education and Training \\ 123 Francis Baard Street, Pretoria \\ Postal Address: Private Bag X174, Pretoria, 0001 \\ Tel.: 012 $3125580 / 81$ \\ Fax: 0123233788 \\ Email:futshane.t@dhet.gov.za
}

\section{Director: Private FET Colleges}

Dr Mandlenkosi Buthelezi

Department of Higher Education and Training

123 Francis Baard Street, Pretoria

Postal Address: Private Bag X174, Pretoria, 0001

Tel.: 0123125672

Fax: 0123239838

Email: buthelezi.m@dhet.gov.za

\author{
Director: Adult Education and Training (AET) Centres \\ Mr David Diale \\ Department of Higher Education and Training \\ 123 Francis Baard Street, Pretoria \\ Postal Address: Private Bag X174, Pretoria, 0001 \\ Tel.: 0123125515 \\ Fax: 0867140276 \\ Email:diale.d@dhet.gov.za
}

Deputy Director: Higher Education Information (HEMIS)

\section{Mr Jacques Appelgryn}

Department of Higher Education and Training

123 Francis Baard Street, Pretoria

Postal Address: Private Bag X174, Pretoria, 0001

Tel.: 0123125480

Fax: 0862989673

Email: appelgryn.j@dhet.gov.za

Data Manager: FET/TVET Colleges and AET Centres Ms Hilda Bartizal

Department of Higher Education and Training

123 Francis Baard Street, Pretoria

Postal Address: Private Bag X174, Pretoria, 0001

Tel.: 0123125414

Fax: 0862989738

Email: bartizal.h@dhet.gov.za 
Director: Sector Education and Training Authorities

(SETAs)

Ms Melissa Erra

Department of Higher Education and Training

123 Francis Baard Street, Pretoria

Postal Address: Private Bag X174, Pretoria, 0001

Tel.: 0123125430

Fax: 0866989734

Email:erra.m@dhet.gov.za

\section{Acting Chief Director: Artisan Development \\ Dr Florus Prinsloo \\ Department of Higher Education and Training \\ 123 Francis Baard Street, Pretoria \\ Postal Address: Private Bag X174, Pretoria, 0001 \\ Tel.: 0112061025 \\ Fax: 0113163284 \\ Email:prinsloo.f@dhet.gov.za}

Chief Director: National Examinations and Assessment (FET/TVET Colleges and AET Centres)

Ms Nadine Pote

Department of Higher Education and Training

222 Struben Street, Pretoria

Postal Address: Private Bag X174, Pretoria, 0001

Tel.: 012 3573892/3

Fax: 0867140115

Email:pote.n@dhet.gov.za

\section{Director: National Skills Fund (NSF) \\ Mr Frans Strydom}

Department of Higher Education and Training

123 Francis Baard Street, Pretoria

Postal Address: Private Bag X174, Pretoria, 0001

Tel.: 0123126211

Fax: 0123231601

Email: strydom.f@dhet.gov.za
Assistant Director: Sector Education and Training Authorities (SETAs)

Mr Lennox Malaka

Department of Higher Education and Training

123 Francis Baard Street, Pretoria

Postal Address: Private Bag X174, Pretoria, 0001

Tel.: 0123125107

Fax: 0862989822

Email:malaka.l@dhet.gov.za

\section{Data Manager: Artisan Development}

Mr Jabulani Ntshingila

Department of Higher Education and Training

INDLELA, Olifanstsfontein

Postal Address: Private Bag X174, Pretoria, 0001

Tel.: 0112061137

Fax: 0113163284

Email:ntshingila.j@dhet.gov.za

\section{Director: Resulting and Certification (IT Systems)}

MrStanford Mphahlele

Department of Higher Education and Training

222 Struben Street, Pretoria

Postal Address: Private Bag X174, Pretoria, 0001

Tel.: 0123573874

Fax: 0862983857

Email:mphahlele.s@dbe.gov.za

\section{Director: Financial Management \\ Ms Amelia Poolman}

Department of Higher Education and Training

123 Francis Baard Street, Pretoria

Postal Address: Private Bag X174, Pretoria, 0001

Tel.: 0123125241

Fax: 0123231413

Email:poolman.a@dhet.gov.za

Chief Executive Officer: National Student Financial Aid

Scheme (NSFAS)

Mr Msulwa Daca

National Student Financial Aid Scheme

Postal Address: Private Bag X6, Plumstead, 7801

Tel.: 0217633200

Fax: 0866063551

Email:msulwa.daca@nsfas.co.za

\author{
General Enquiries \\ Higher Education and Training Information System (HETIS) Officer \\ Ms Kirstin Barth \\ Department of Higher Education and Training \\ Postal Address: Private Bag X174, Pretoria, 0001 \\ Tel.: $0123125212 / 5039$ \\ Fax: 0123262069 \\ Email:HETIS.Officer@dhet.gov.za
}





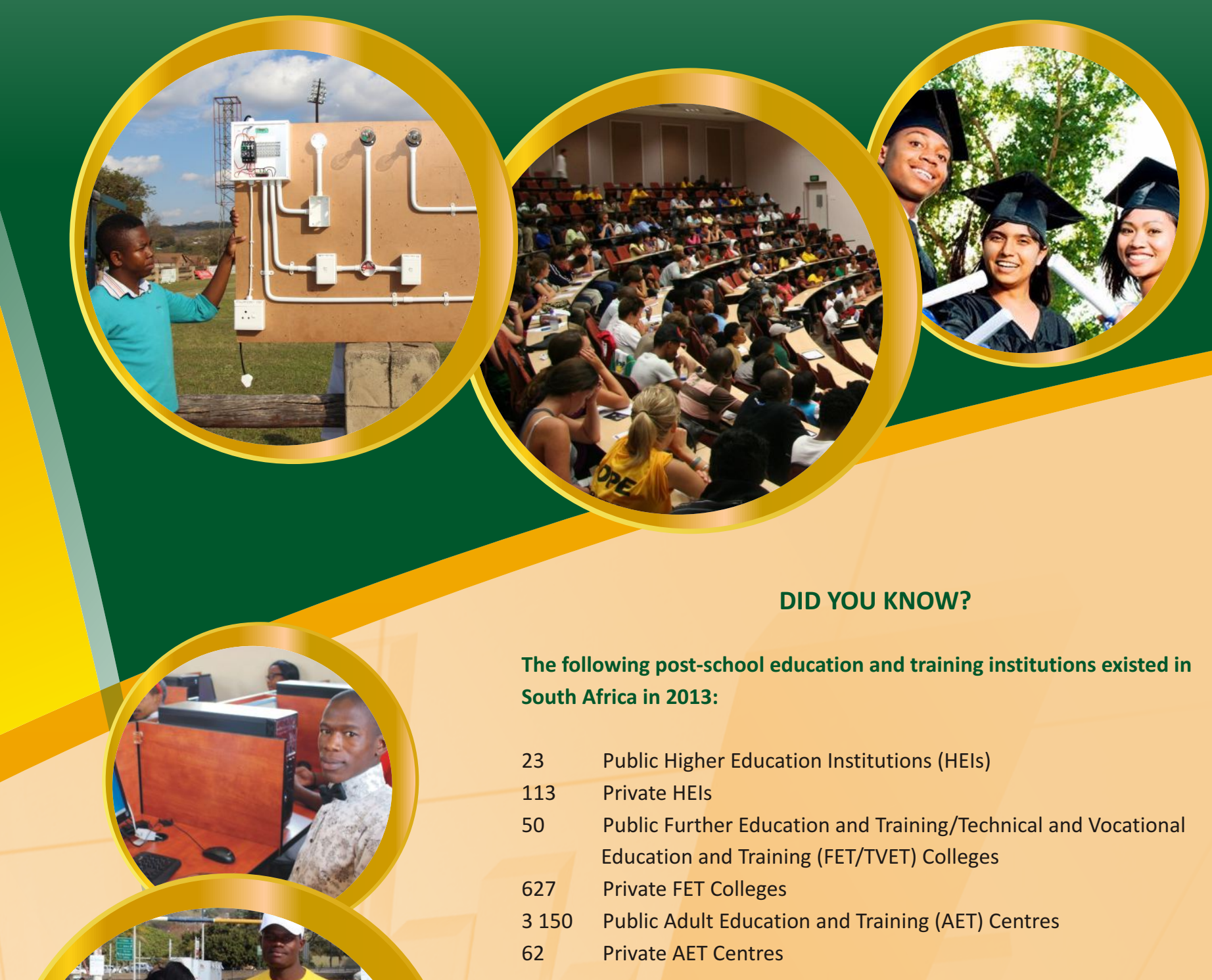

Student enrolment in the post-school education and training sector in 2013 was as follows:

Public HEls: 983698

Private HEls: 119941

Public FET/TVET Colleges: 639618

Private FET Colleges: $154632 *$ Public AET Centres: $249507^{* *}$

\section{Private AET Centres:}

Sector Education and Training Authority (SETA) Programmes: 176298

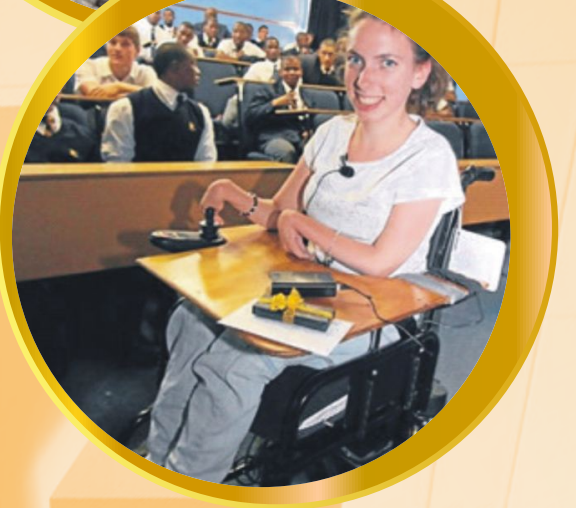

* This figure represents enrolment at only 503 of the 627 private FET Colleges that responded to the departmental Annual Survey.

** This figure represents enrolment at only 1761 of the 3150 public AET Centres that responded to the departmental Annual Survey.

*** The number of private AET Centres reflect the number of Centres that responded to the departmental Annual Survey 